Daniela Tiaki Uehara

\title{
Pesquisa de microrrearranjos em genes candidatos a surdez sindrômica e não-sindrômica
}


Daniela Tiaki Uehara

\section{Pesquisa de microrrearranjos em genes candidatos a surdez sindrômica e não-sindrômica}

Dissertação apresentada ao Instituto de Biociências da Universidade de São Paulo, para a obtenção de Título de Mestre em Ciências, na Área de Biologia/Genética.

Orientadora: Profa. Dra. Regina Célia Mingroni Netto 


\section{Ficha Catalográfica}

Uehara, Daniela Tiaki

Pesquisa de microrrearranjos em genes

candidatos a surdez sindrômica e não-sindrômica.

88 pp.

Dissertação (Mestrado) - Instituto de

Biociências da Universidade de São Paulo.

Departamento de Genética e Biologia Evolutiva.

1. Surdez hereditária

2. Surdez sindrômica

3. Surdez não-sindrômica

4. $\mathrm{CNV}$

5. MLPA

Comissão Julgadora:

$\operatorname{Prof}(a) \cdot \operatorname{Dr}(a)$

Prof(a). Dr(a).

Profa. Dra. Regina Célia Mingroni Netto

Orientadora 
A meus pais e avós, por todo o esforço empregado na vida para dar melhor futuro a seus filhos. 
「学問に近道なし」

Provérbio japonês 


\section{Agradecimentos}

À minha orientadora Profa. Dra. Regina Célia Mingroni Netto, por sua dedicação e confiança comigo, além da acolhida no laboratório desde meu último ano de graduação.

À Dra. Juliana Forte Mazzeu, que desde o começo do projeto me auxiliou em tudo que se referisse a MLPA e, mesmo à distância, sempre teve muita disposição para me ajudar.

À Prof. Dra. Carla Rosenberg, que concebeu e deu sugestões valiosas no decorrer deste projeto, e também à Dra. Ana Cristina Krepischi e Dra. Ana Lúcia Catelani, pela colaboração.

À Dra. Erika Freitas, que executou todos os experimentos de array-CGH para confirmação de nossos resultados.

À Profa. Dra. Angela Maria Vianna Morgante, pela revisão do resumo.

À Dra. Fernanda Jehee, pelas sugestões com MLPA.

Ao Dr. Alfredo Tabith Jr. e toda a equipe de profissionais da DERDIC-PUC/SP, pela avaliação audiológica de parte da casuística.

À Maria Teresa Balester de Mello Auricchio, pelo auxilio técnico e amizade.

Aos funcionários do Laboratório de Genética Humana, do Centro de Estudos do Genoma Humano, do Departamento de Genética e Biologia Evolutiva e do Instituto de Biociências da USP.

Aos meus colegas de laboratório Ana Carla, Daniel, Dayane, Karina, Lilian, Magnolia, Renata Nonose, Renata Thiele e Vítor. Agradeço em especial ao Daniel, que com muita paciência me ensinou quase todas as práticas laboratoriais logo que entrei; à Lilian e Karina, pelo apoio científico e pela grande disposição em me ajudar; e à Renata Thiele, grande companheira de esticadas no laboratório (além do agregado Gustavo).

Aos demais colegas dos laboratórios vizinhos, em especial ao Adriano, que me auxiliou nos primeiros experimentos de MLPA.

A todos os pacientes e familiares que participaram deste projeto.

Aos meus pais que, apesar de não entenderem bem o que eu fiz nesses últimos anos, nunca questionaram minhas escolhas pela prioridade que sempre deram à educação.

A todas as outras pessoas ou criaturas que passaram por minha vida e contribuíram de alguma forma para que eu realizasse este projeto.

À Profa. Dra. Mayana Zatz, coordenadora do Centro de Estudos do Genoma Humano, pela infraestrutura que permitiu a realização deste estudo.

Ao Departamento de Genética e Biologia Evolutiva e o Instituto de Biociências da USP, pela infraestrutura.

À FAPESP, pelo auxílio financeiro.

À CAPES, pela bolsa de mestrado. 


\section{Índice Geral}

Resumo 1

$\begin{array}{ll}\text { Abstract } & 3\end{array}$

$\begin{array}{lc}\text { I. Introdução } & 5\end{array}$

I.1. Fisiologia da audição 6

$\begin{array}{ll}\text { I.2. A deficiência auditiva } & 8\end{array}$

I.2.1. Classificação clínica 9

I.3. A deficiência auditiva de etiologia genética 10

I.3.1. Surdez não-sindrômica 11

I.3.1.1. Herança autossômica recessiva 14

I.3.1.2. Herança autossômica dominante 16

I.3.1.3. Herança ligada ao X 16

I.3.1.4. Herança mitocondrial 16

I.3.2. Surdez sindrômica 17

I.4. Variações no número de cópias e doenças genéticas 18

I.5. Técnicas de análise genética de alta resolução: Array-CGH e MLPA 20

I.5.1. Array-CGH 22

$\begin{array}{ll}\text { I.5.2. MLPA } & 23\end{array}$

I.6. Justificativa do estudo 25

$\begin{array}{lr}\text { II. Objetivo } & 28\end{array}$

III. Casuística e Métodos $\quad 30$

III.1. Casuística 31

III.2. Métodos $\quad 32$

III.2.1. Seleção de genes candidatos 32

III.2.2. Construção das sondas in-house de MLPA 37

III.2.3. Extração de DNA 40 
III.2.4. A reação de MLPA e a interpretação dos resultados

III.2.5. Sequenciamento de DNA 45

III.2.6. Triagem de uma variante não descrita por PCR-RFLP (Restriction 46 Fragment Length Polymorphism)

$\begin{array}{ll}\text { IV. Resultados e Discussão } & 47\end{array}$

IV.1. Padronização das sondas in-house de MLPA $\quad 48$

IV.2. Comparação entre os resultados do array-CGH e os resultados do MLPA 49

IV.3. Triagem de alterações na casuística selecionada por MLPA 55

IV.4. Investigação das alterações detectadas por MLPA 56

IV.4.1. Investigação das alterações no gene TMC6 56

IV.4.2. Investigação das alterações no gene STRC 60

IV.4.3. Investigação da alteração no gene IMMP2L 63

IV.4.3.1. Os genes IMMP2L e DOCK4 66

$\begin{array}{ll}\text { IV.5. Conclusões } & 72\end{array}$

V. Referências Bibliográficas $\quad 74$

$\begin{array}{ll}\text { VI. Anexos } & 82\end{array}$ 


\section{Índice de Figuras}

Fig. 1. Ilustração esquemática da cóclea e sua secção transversal. Em destaque, esquema detalhado do órgão

de Corti e micrografia dos estereocílios das células ciliadas (Fonte: "The inner ear", capítulo "The auditory system" do livro "Neuroscience", disponível no NCBI Bookshelf-

http://www.ncbi.nlm.nih.gov/bookshelf/br.fcgi?book=neurosci\&part=A894).

Fig. 2. Ilustração esquemática da reação de MLPA (modificado de Schouten e col., 2002).

Fig. 3. Esquema representando uma sonda in-house de MLPA e seus componentes. A barra em vermelho representa a sequência alvo de DNA à qual se hibridam as duas sequências, proximal e distal, representadas por barras em azul. As barras pretas adjacentes às barras azuis correspondem às sequências complementares ao par de primers. A extremidade 5' da sequência distal deve ser fosforilada para permitir a ligação entre as duas sequências.

Fig. 4. Duplicação no Paciente 3 em 6p25.3p25.2. A barra verde representa a região cromossômica, as barras azuis representam os genes e as barras amarelas representam os clones de $1 \mathrm{Mb}$. A barra vermelha superior representa a duplicação como mapeada pelo array-CGH de $1 \mathrm{Mb}$ e a barra vermelha inferior, pelos oligoarrays de 105k e MLPA. As linhas tracejadas representam as regiões não cobertas pelas sondas de array-CGH e que poderiam também estar comprometidas pelo rearranjo. No gráfico inferior estão os resultados de MLPA correspondentes às sondas de cada gene.

Fig. 5. Duplicação no Paciente 5 em 2q12.3. A barra verde representa a região cromossômica, a barra azul representa o gene $S L C 5 A 7$, as barras amarelas representam os clones de $1 \mathrm{Mb}$, a barra vermelha superior representa a duplicação como mapeada pelo array-CGH de $1 \mathrm{Mb}$ e a barra vermelha inferior, a duplicação como mapeada com a informação adicional do MLPA. As linhas tracejadas representam as regiões não cobertas pelos clones de $1 \mathrm{Mb}$ e que poderiam estar incluídas no rearranjo. No gráfico inferior está o resultado de MLPA correspondente à sonda para o gene SLC5A7.

Fig. 6. Deleção no Paciente 6 em 4q24. A barra verde representa a região cromossômica, as barras azuis representam os genes, as barras amarelas representam os clones de $1 \mathrm{Mb}$, a barra vermelha superior representa a deleção como mapeada pelo array-CGH de $1 \mathrm{Mb}$ e a barra vermelha inferior, a deleção como mapeada com a informação adicional do MLPA. As linhas tracejadas representam as regiões não cobertas pelos clones e que poderiam também estar incluídas no rearranjo. A linha verde tracejada vertical indica a região correspondente ao éxon 12 de PPP3CA. No gráfico inferior está o resultado de MLPA correspondente à sonda para PPP3CA.

Fig. 7. Deleção em 7q31.1 no Paciente 7. A barra verde representa a região cromossômica, as barras azuis representam os genes e as barras amarelas representam os clones de $1 \mathrm{Mb}$. A barra vermelha superior representa a duplicação como mapeada pelo array-CGH de $1 \mathrm{Mb}$ e a barra vermelha inferior, pelos oligoarrays de 44k. As regiões não cobertas pelas sondas possivelmente comprometidas pelo rearranjo estão representadas pelas linhas pretas tracejadas. As linhas verdes tracejadas na vertical indicam as regiões correspondentes à sonda para LRRN3 e à sonda para IMMP2L, em seu $2^{\circ}$ éxon. No gráfico inferior estão os resultados de MLPA correspondentes às sondas de cada gene. E: éxon.

Fig. 8. Deleção no Paciente 8 em 15q15.3. A barra verde representa a região cromossômica, as barras azuis representam os genes e pseudogenes dessa região, as barras amarelas representam os clones de $1 \mathrm{Mb}$, incluindo RP11-263I19, a barra vermelha superior representa a deleção como mapeada pelo array-CGH de 1 $\mathrm{Mb}$, e a inferior, com a informação adicional do MLPA. As regiões não cobertas pelas sondas e possivelmente comprometidas pelo rearranjo estão representadas pelas linhas pretas tracejadas. As linhas verdes tracejadas na vertical indicam as regiões correspondentes às duas sondas para STRC, desenhadas em seus íntrons 18 e 22. No gráfico inferior estão os resultados de MLPA correspondentes à sonda para $M A P 1 A$ e às sondas para STRC a partir dos íntrons 18 e 22. I: íntron. 
Fig. 9. Representação da região duplicada em tandem em 15q15.3 englobando os genes HISPPD2A, CKMT1B, STRC e CATSPER2. Os genes e peseudogenes estão representados pelas barras azuis; os pseudogenes estão identificados pelo símbolo $\Psi$. Cen: centrômero; tel: telômero (modificado de Avidan e col., 2003).

Fig. 10. Suposta deleção no gene TMC6 nos Pacientes 25 e 29. (A) Perfil das 25 sondas de MLPA em cada paciente, com destaque para as deleções em heterozigose em TMC6 (setas vermelhas). O Paciente 25 também apresentou deleção no gene $S T R C$. (B) Estudos de segregação da alteração no gene TMC6 nas famílias dos pacientes, indicando que a deleção era supostamente de novo nos dois casos.

Fig. 11. Alinhamento da sequência da sonda para TMC6, desenhada no éxon 17, com outra região do cromossomo 2 usando o genoma de referência GRCh37/hg19. As letras maiúsculas em azul representam as bases do éxon 17 de TMC6 nas quais há correspondência com as bases da região do cromossomo 2 homóloga. As bases sem correspondência são representadas pelas letras minúsculas em vermelho. A seta indica a região de ligação entre as sequências proximal e distal da sonda.

Fig. 12. Genealogias dos casos familiais de portadores de rearranjos no gene STRC. (A) Família 97; (B) Família 119; (C) Família 128; (D) Família 146. As setas indicam os propósitos e os asteriscos indicam os indivíduos com amostras submetidas a MLPA.

Fig. 13. Duplicação no gene IMMP2L na Paciente 78. (A) Perfil das 25 sondas de MLPA na paciente, com destaque para a duplicação em IMMP2L (seta vermelha). (B) Estudo de segregação da duplicação no gene IMMP2L na família da paciente, em que se observou que o rearranjo foi herdado da mãe afetada.

Fig. 14. Genealogia da família da Paciente 78. A seta indica a propósita e os asteriscos indicam os indivíduos com amostras submetidas a MLPA.

Fig. 15. Perfil da duplicação em 7q31.1 da Paciente 78 por array-CGH de 180k, mostrando o resultado alterado em 36 sondas.

Fig. 16. Esquema ilustrando o mapeamento da duplicação na Paciente 78 em 7q31.1 por meio de oligoarrays de 180k. A duplicação, de no mínimo 438 kb, engloba os éxons 1, 2 e 3 do gene IMMP2L e pelo menos os éxons 45 a 52 do gene DOCK4. As linhas pretas tracejadas simbolizam as regiões em que podem se localizar os pontos de quebra proximal e distal e que não são cobertas pelas sondas. As linhas verdes tracejadas indicam as localizações correspondentes, em cada gene, às últimas sondas duplicadas, e as linhas amarelas tracejadas, às primeiras sondas não duplicadas. Cen: centrômero; tel: telômero.

Fig. 17. CNVs catalogadas na região dos genes IMMP2L e DOCK4 em 7q31.1 e visualizadas pelo genome browser do banco de dados DGV. Observa-se a ocorrência de várias CNVs, principalmente deleções (em azul), abrangendo IMMP2L. Por outro lado, quatro CNVs incluem DOCK4, nenhuma abrangendo sua porção 3', em que três delas são deleções (em azul) e uma duplicação (em vermelho).

Fig. 18. Representação esquemática de parte da região 7q31.1, mostrando os marcadores do tipo microssatélite no segmento destacado, intervalos para DFNB4, DFNB14, DFNB17 e AVA (= DFNB4) e a localização dos genes SLC26A4, IMMP2L e DOCK4 (barras azuis). Os intervalos entre os marcadores não refletem a real distância entre eles. Cen: centrômero; tel: telômero; AVA: aqueduto vestibular alargado. 


\section{Índice de Tabelas}

Tabela I. Genes de surdez não-sindrômica e função dos produtos no processo da audição (modificado de Hilgert e col., 2009a).

Tabela II. Exemplos de CNVs relacionadas a doenças de herança mendeliana (modificado de Zhang e col., 2009).

Tabela III. Principais critérios para a avaliação do significado de uma CNV (Lee e col., 2007).

Tabela IV. Achados clínicos dos pacientes com rearranjos genômicos detectados por array-CGH

(modificado de Catelani e col., 2009).

Tabela V. Genes candidatos selecionados a partir de rearranjos detectados por array-CGH e dados da

literatura. Os tamanhos estimados (em $\mathrm{Mb}$ ) se referem aos resultados de array-CGH de $1 \mathrm{Mb}$.

Tabela VI. Conjunto MLPA-A, com as sondas correspondentes aos genes, região cromossômica, sequências proximal e distal para hibridação e posição genômica de cada sonda (da extremidade 5' da sequência proximal até a extremidade 3' da sequência distal).

Tabela VII. Conjunto MLPA-B, com as sondas correspondentes aos genes, região cromossômica, sequências proximal e distal para hibridação e posição genômica de cada sonda (da extremidade 5' da sequência proximal até a extremidade 3' da sequência distal).

Tabela VIII. Novas sondas para IMMP2L, STRC e TMC6, com suas sequências proximal e distal para hibridação e posição genômica de cada sonda (da extremidade 5' da sequência proximal até a extremidade 3' da sequência distal).

Tabela IX. Sequências dos primers para sequenciamento dos genes TMC6 e IMMP2L.

Tabela X. Resultados obtidos por MLPA em amostras dos sete pacientes portadores de surdez sindrômica previamente estudados por array-CGH.

Tabela XI. Alterações detectadas por MLPA em amostras de 163 pacientes com surdez sindrômica ou não-sindrômica.

Tabela XII. Frequências de alterações nos genes IMMP2L, TMC6 e STRC detectadas em pacientes com surdez e em indivíduos controle.

Tabela XIII. Resultado de MLPA para três sondas no gene TMC6 em cinco dos seis pacientes da 


\section{Resumo}

A complexidade da fisiologia da audição resulta da participação e interação de produtos de grande número de genes, razão pela qual a surdez hereditária exibe enorme heterogeneidade genética. Estudos moleculares nas duas últimas décadas permitiram a identificação de vários genes responsáveis por surdez; entretanto, muitos ainda restam ser identificados. A maioria dos estudos de mapeamento de genes de surdez até então conduzidos privilegiou estratégias que buscavam mutações de ponto. Outros mecanismos mutacionais, como deleções e duplicações, foram pouco investigados. Portanto, a contribuição das CNVs (Copy Number Variations) na surdez hereditária é pouco conhecida.

O objetivo desse trabalho foi identificar novos genes que possam ter papel na etiologia da surdez sindrômica ou não-sindrômica por meio da investigação de microdeleções e microduplicações em pacientes com perda auditiva. Selecionamos 25 genes candidatos (CTTN, FGF3, FGF19, FOXC1, FOXF2, FOXQ1, IMMP2L, KIF5C, LRRN3, MAP1A, MYLK4, PPP3CA, SHANK2, SLC5A7, STRC, TMC1, TMC2, TMC3, TMC4, TMC5, TMC6, TMC7, TMC8, TPCN2 e TUBB2A) para a triagem de microrrearranjos por meio da técnica de MLPA (Multiplex Ligation-dependent Probe Amplification). Os genes candidatos foram selecionados a partir de rearranjos detectados em um estudo prévio realizado por meio de array-CGH (Array-based Comparative Genomic Hybridization) em indivíduos com surdez sindrômica estudados em nosso laboratório, e também a partir de dados da literatura. Nossa casuística foi composta por 163 indivíduos, dos quais 74 são pacientes com surdez associada a outros sinais (sindrômicos), a maioria casos isolados, e 89 são pacientes com surdez não-sindrômica, propósitos de famílias em que segrega surdez de herança autossômica dominante ou recessiva. Desenhamos uma sonda sintética intragênica de MLPA para cada um dos genes candidatos.

Foram detectadas seis deleções em TMC6 (3,7\%), seis deleções e uma duplicação em STRC (4,3\%) e uma duplicação em IMMP2L (0,6\%). A triagem de alterações nesses três genes em 189 indivíduos fenotipicamente normais revelou quatro deleções em TMC6 (2,1\%), oito deleções e três duplicações em STRC (5,8\%) e três deleções em IMMP2L (1,6\%). Todas as alterações em TMC6, tanto nos casos de surdez como nos controles, eram na realidade artefatos devidos a problemas de hibridação da sonda correspondente. 
No gene $S T R C$, previamente já relacionado à surdez, os rearranjos nos indivíduos afetados devem se tratar de polimorfismos sem efeito fenotípico por serem muito frequentes na população. Contudo, é possível que haja nesses pacientes mutações adicionais que não puderam ser rastreadas e que poderiam contribuir ao fenótipo, em combinação com o rearranjo detectado, como já descrito em um caso da literatura. A duplicação em IMMP2L em uma paciente com surdez não-sindrômica, herdada da mãe igualmente afetada, mostrou-se a mais provavelmente relacionada ao fenótipo, pois o estudo complementar por meio de array-CGH revelou que o rearranjo inclui uma duplicação parcial da porção 3' de outro gene, DOCK4. O produto desse gene possui uma isoforma que se localiza nos estereocílios das células ciliadas e se liga a uma importante proteína relacionada à audição, a harmonina. Portanto, nossa hipótese é a de que a duplicação seja a causa da surdez na família e que DOCK4 seja um novo gene responsável por surdez. A associação de IMMP2L com surdez é menos provável devido ao grande número de CNVs não patogênicas já descritas que incluem partes desse gene. Estudos complementares são necessários para mapear a duplicação com mais precisão. Além disso, o rastreamento de mutações em DOCK4 em outras famílias com surdez pode vir a confirmar o possível papel desse gene na etiologia da surdez. 


\section{Abstract}

Several genes contribute to the complexity of physiology of hearing. Consequently, hereditary deafness is extremely heterogeneous from the genetic point of view. In the last two decades, several genes responsible for hereditary hearing loss have been identified, but a large number of genes remains to be found, as evidenced by the unexplained cases of inherited deafness. The search for point mutations in candidate genes after mapping based on linkage studies has been the main strategy in the identification of such genes. Other mutation mechanisms, such as deletions and duplications, have been rarely investigated, and the contribution of DNA copy number variants (CNVs) to hearing loss is not well known.

This study aimed at identifying novel genes, which might play a role in the etiology of syndromic and non-syndromic deafness, through the search of gene microdeletions and microduplications. We selected 25 candidate genes (CTTN, FGF3, FGF19, FOXC1, FOXF2, FOXQ1, IMMP2L, KIF5C, LRRN3, MAP1A, MYLK4, PPP3CA, SHANK2, SLC5A7, STRC, TMC1, TMC2, TMC3, TMC4, TMC5, TMC6, TMC7, TMC8, TPCN2 and TUBB2A) based on their involvement in microimbalances detected by Array-based Comparative Genomic Hybridization (aCGH) in a previous study of a Brazilian sample of individuals with syndromic hearing loss from our laboratory and others reported in the literature. We studied 163 subjects, 74 of them presenting syndromic deafness, the majority were isolated cases, and 89 being probands of families in which nonsyndromic deafness had an autosomal dominant or recessive mode of inheritance. Gene deletions or duplications were screened by Multiplex Ligant-dependent Probe Amplification (MLPA) using one synthetic intragenic probe designed for each candidate gene.

We detected six deletions in TMC6 (3,7\%), six deletions and one duplication in STRC (4,3\%), and one duplication in IMMP2L (0,6\%). The screening of imbalances in these genes in a control sample of 189 hearing individuals revealed four deletions in TMC6 $(2,1 \%)$, eight deletions and three duplications in STRC (5,8\%) and three deletions in IMMP2L (1,6\%). The imbalances found in TMC6, both in affected and control individuals, were in fact artifacts due to problems in the hybridization of the corresponding probe. As to the STRC gene, previously related to deafness, the imbalances are more likely to be 
polymorphisms with no phenotypic effect. However, the possibility remains that additional undetected mutations in affected individuals contribute to their phenotype, in combination with the microrearrangement, as already reported in the literature. The duplication in IMMP2L in a non-syndromic patient, and also present in her affected mother, is most likely causative of deafness, since a complementary study performed with aCGH revealed that the rearrangement included a partial duplication of the 3 ' end of another gene, DOCK4. An isoform of the DOCK4 protein localizes to the stereocilia in the inner ear and interacts with harmonin, a protein already known to be involved in hearing. We hypothesize that this duplication may be the cause of deafness in the family and, this being the case, DOCK4 appears as a novel deafness gene. The causal association between IMMP2L and deafness is less plausible, because of the large number of reported non-pathogenic CNVs that include parts of this gene. Further studies are required to precisely map this duplication. In addition, the screening of mutations in DOCK4 in other families with hearing impairment is required to evaluate its possible role in the etiology of deafness. 


\section{INTRODUÇÃO}




\section{INTRODUÇÃO}

\section{I.1. Fisiologia da audição}

As informações que se seguem acerca da fisiologia da audição foram resumidas a partir da revisão de Dror e Avraham (2009) e do capítulo “The Auditory System”, da 2a edição do livro "Neuroscience", editado por Purves e col. (2001) e disponível no NCBI Bookshelf (http://www.ncbi.nlm.nih.gov/bookshelf/br.fcgi?book=neurosci).

O sistema auditivo transforma as ondas sonoras em padrões distintos de atividade neural, que se integram às informações vindas de outros sistemas sensoriais para gerar respostas. O primeiro estágio dessa transformação se dá nas orelhas externa e média, locais onde ocorre a captação do som e amplificação da pressão sonora, de modo que essa energia possa ser transmitida com sucesso para a orelha interna. Na orelha interna, uma série de processos bioquímicos decompõe o estímulo original em elementos mais simples, de maneira que informações sobre frequência, amplitude e fase são transduzidos por células especializadas e convertidas em atividade elétrica para as fibras do nervo acústico.

Nesse processo tem papel central a cóclea, estrutura que se localiza na orelha interna. A cóclea é um canal ósseo-membranoso em formato de caracol e dividido em três compartimentos preenchidos por fluidos: as escalas média, vestibular e timpânica. A escala média contém o órgão de Corti, que é a porção sensorial propriamente dita do sistema auditivo. Esse órgão, situado na membrana basilar, é constituído por células de suporte e por aproximadamente 16.000 células sensoriais denominadas células ciliadas. Essas podem ser de dois tipos, internas e externas. A porção apical das células ciliadas contém projeções especializadas ricas em actina denominadas estereocílios. Uma membrana acelular, denominada tectória, cobre o epitélio de células ciliadas. A Fig. 1 traz uma ilustração esquemática da cóclea e detalhe de suas porções, evidenciando a localização das células ciliadas do órgão de Corti e dos estereocílios.

Quando o som é captado, fluidos se movem pela escala média e fazem vibrar a membrana basilar e a membrana tectória. As vibrações são o gatilho para a deflexão dos 
estereocílios, permitindo o influxo de íons potássio por meio da abertura de canais que irão despolarizar a membrana das células ciliadas internas. Essa despolarização provoca a liberação de vesículas contendo neurotransmissores nas células ciliadas internas ou externas que irão desencadear o impulso nervoso e assim transmitir a informação ao cérebro via nervo acústico.

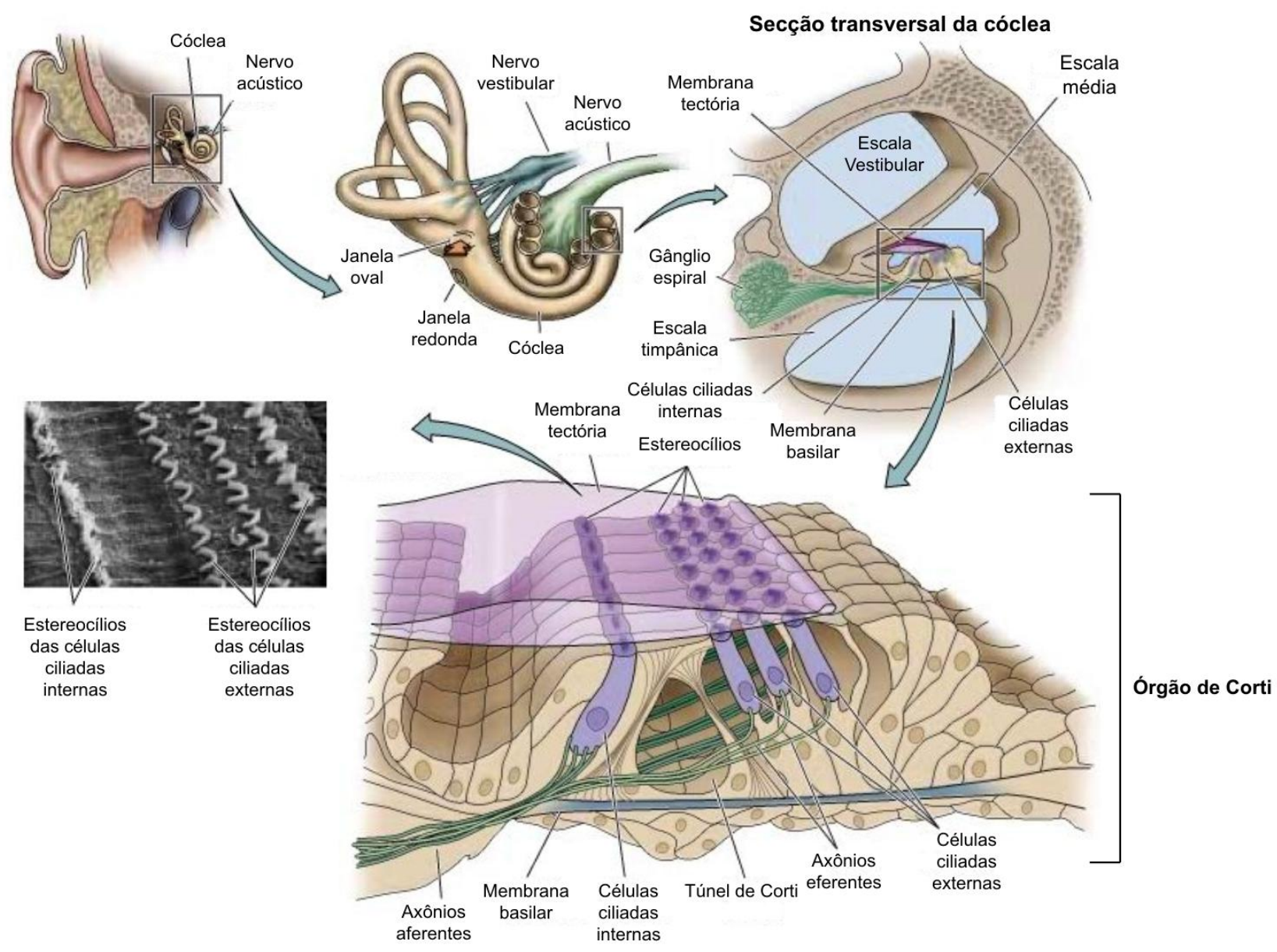

Fig. 1. Ilustração esquemática da cóclea e sua secção transversal. Em destaque, esquema detalhado do órgão de Corti e micrografia dos estereocílios das células ciliadas (Fonte: "The inner ear", capítulo "The auditory system" do livro "Neuroscience", disponível no NCBI Bookshelf http://www.ncbi.nlm.nih.gov/bookshelf/br.fcgi?book=neurosci\&part=A894). 


\section{I.2. A deficiência auditiva}

A deficiência ou perda auditiva é a condição na qual existe uma incapacidade parcial ou total de detecção ou percepção do som. É considerada o distúrbio sensorial mais prevalente em humanos e pode ser resultante de causas genéticas, ambientais ou de ambas (Hutchin e Cortopassi, 2000). A audição é fundamental para que ocorra o desenvolvimento da fala e do aprendizado da criança. Portanto, a perda ou a diminuição da capacidade auditiva pode comprometer seriamente a aquisição da linguagem e a capacidade de comunicação. Aproximadamente 70 milhões de pessoas no mundo inteiro sofrem desse distúrbio e é estimado que cerca de 30\% dos adultos exibirão perda auditiva significativa a partir dos 65 anos de idade (Hutchin e Cortopassi, 2000). Em países desenvolvidos, aproximadamente uma a cada 1.000 crianças nasce com deficiência auditiva grave o suficiente para requerer educação especial, sendo que em 50-60\% dos casos, a deficiência é devida a causas genéticas e, em 40-50\% dos casos, é adquirida devido a causas ambientais (Finsterer e Fellinger, 2005). Os fatores ambientais incluem frequente exposição a ruído, trauma acústico, infecções virais ou bacterianas e uso de drogas ototóxicas, enquanto os casos de etiologia genética ocorrem devidos a mutações em diferentes genes ou elementos regulatórios relacionados ao desenvolvimento da estrutura e função da orelha (Dror e Avraham, 2009).

No Brasil, estima-se que quatro em 1.000 indivíduos apresentem o defeito ao nascimento e, até a década de noventa, a deficiência auditiva hereditária era responsável por cerca de 16\% do total de casos de surdez no país (Braga e col., 1999). Essa frequência é baixa se comparada aos países desenvolvidos, onde tal valor pode chegar a $60 \%$. Isso se deve ao fato de que, em nosso país, a surdez decorrente de causas ambientais como rubéola materna, meningite e exposição a drogas ototóxicas ainda é mais frequente, embora esse quadro possa estar se alterando graças a melhorias na saúde pública. Entretanto, há poucos estudos epidemiológicos recentes que demonstrem tal tendência. Em um desses estudos, Nóbrega e col. (2005) compararam as principais causas de surdez em crianças atendidas no Departamento de Otorrinolaringologia e de Distúrbios da Comunicação Humana da Universidade Federal de São Paulo (UNIFESP) entre os 
períodos de 1990-1994 e 1994-2000, e verificaram que as frequências da surdez de etiologia genética nos dois períodos variaram de 6,9 a 14\%.

Os termos "perda" ou "deficiência auditiva" são comumente utilizados para se referir a qualquer déficit ou comprometimento auditivo abaixo dos níveis considerados normais para a audição. Já o termo "surdez" implica em um comprometimento auditivo geralmente grave ou profundo (Smith e col., 2010). Utilizaremos neste trabalho, porém, os três termos como sinônimos, do mesmo modo que esses termos têm sido tratados na maioria dos trabalhos de genética, pois muitas vezes perdas genéticas com a mesma etiologia exibem gravidade de manifestação muito variável.

\section{I.2.1. Classificação clínica}

Clinicamente, a classificação da surdez pode seguir vários critérios. Em relação à manifestação clínica, a surdez é dividida em não-sindrômica, na qual se tem a surdez como único sinal clínico, sem fenótipos adicionais, e sindrômica, caracterizada por perda de audição em combinação com outras anormalidades. Quanto à idade de manifestação, a surdez é pré-lingual, quando se manifesta antes ou durante o aprendizado da linguagem, ou pós-lingual, se sua manifestação ocorre após a aquisição da linguagem.

Segundo Davis e Silverman (1970), a surdez pode ser classificada quanto ao valor dos limiares auditivos em decibéis (dB) como leve (21-40 dB), moderada (41-70 dB), grave (71-90 dB) ou profunda (>91 dB). Em relação à localização do defeito, se estiver na orelha externa e/ou média, ou seja, afetar a condução do som até a orelha interna, a surdez é classificada como condutiva. Se o defeito ocorrer a partir da orelha interna até o encéfalo, por exemplo, comprometendo as células ciliadas da cóclea, o nervo acústico ou outras estruturas, é classificada como sensorioneural. Existem ainda casos onde pode haver uma combinação de ambos os tipos de defeito, sendo a surdez classificada como mista.

Outro critério de classificação é a lateralidade, no qual a perda é dita unilateral quando somente uma orelha é afetada, e bilateral, quando ambas são afetadas. Por fim, quanto à evolução, a surdez pode ser chamada de estacionária quando não se altera com o tempo, ou progressiva, quando primeiramente surge como leve e evolui para um quadro mais grave ou ainda para outras frequências (revisão em Smith e col., 2010). 


\section{I.3. A deficiência auditiva de etiologia genética}

A surdez de etiologia genética é um exemplo notável das doenças geneticamente heterogêneas, isto é, aquelas em que fenótipos idênticos ou similares decorrem de mutações em locos diferentes ou de diferentes mecanismos genéticos. A heterogeneidade genética pode ser classificada como alélica ou de locos. O primeiro termo é usado para se referir ao caso de mutações diferentes em um mesmo gene, e o segundo, a fenótipos clínicos semelhantes causados por mutações em diferentes locos gênicos.

A descoberta de produtos gênicos relevantes à função auditiva por meio da identificação de genes responsáveis por surdez contribuiu com uma fração considerável do conhecimento acerca da biologia molecular da orelha interna (Dror e Avraham, 2009). De acordo com a revisão de Finsterer e Fellinger (2005), estima-se que 300 a 500 genes sejam necessários à audição. Dada a complexidade da fisiologia da audição, não é de se admirar o grande número de genes relacionados e o fato de a surdez exibir uma enorme heterogeneidade genética. Em geral, os genes mutados que levam à deficiência auditiva codificam proteínas que atuam na morfogênese dos cílios das células ciliadas, proteínas relacionadas à homeostase iônica da cóclea, componentes da matriz extracelular e fatores de transcrição, entre outras funções (Hilgert e col., 2009b).

Com relação aos mecanismos de herança, é estimado que cerca de 75-80\% dos casos de surdez genética não-sindrômica sejam de herança autossômica recessiva, 20-25\% de herança autossômica dominante e uma pequena porcentagem de herança ligada ao X, em torno de 1 a 1,5\% (revisão em Smith e col., 2010). A frequência da herança mitocondrial não é muito bem conhecida, sendo estimada em 1\% dos casos genéticos (Kokotas e col, 2007).

Os diferentes locos ou regiões candidatas a conterem um ou mais genes responsáveis por surdez são designados DFN (do inglês DeaFNess) e numerados seguindo a ordem de descoberta. Os locos que supostamente contêm genes de surdez de herança autossômica recessiva são denominados $\mathrm{DFNB}$, aqueles com padrão autossômico dominante de DFNA e os locos que estão no cromossomo X são designados DFNX. Segundo o Hereditary Hearing Loss Homepage (http://hereditaryhearingloss.org/), de Van Camp e Smith (última atualização em outubro de 2010), até o momento, 61 locos de 
surdez não-sindrômica de herança autossômica recessiva foram mapeados com a identificação de 36 genes, 49 locos foram mapeados com 24 genes identificados para a herança autossômica dominante e, para a herança ligada ao X, cinco locos foram mapeados com a identificação de dois genes. Adicionalmente, dois locos identificados como genes modificadores também já foram mapeados. Em relação à herança mitocondrial, dois

principais genes foram identificados e muitas mutações diferentes nesses genes foram relacionadas à surdez hereditária não-sindrômica.

Além do enorme número de genes relacionados com a surdez, outros fatores contribuem para aumentar a complexidade da genética da audição: em um mesmo gene, existem mutações que estão associadas a diferentes padrões de herança. Por exemplo, diferentes mutações que ocorrem nos genes GJB2, GJB6, MYO7A, TECTA e TMC1 têm comportamento dominante ou recessivo. Estudos moleculares também têm demonstrado que diferentes mutações no mesmo gene podem causar surdez sindrômica e nãosindrômica, como é o caso dos genes SLC26A4, USH1C e WFS1 (Smith e col., 2010). Dessa maneira, fica evidente a grande heterogeneidade genética da surdez.

A surdez também pode ser de origem multifatorial ou complexa, resultando da interação de vários fatores genéticos e ambientais. Um exemplo é a presbiacusia, que é a diminuição da capacidade auditiva relacionada ao envelhecimento. Até o momento, poucos genes foram associados a esse tipo de surdez. Não se sabe se genes relacionados a formas monogênicas de surdez também podem estar associados à surdez de mecanismo multifatorial (Hilgert e col., 2009b).

\section{I.3.1. Surdez não-sindrômica}

Apesar de a surdez estar relacionada a várias doenças e síndromes que têm o distúrbio como um de seus sinais clínicos, 70\% dos casos de surdez hereditária são nãosindrômicos (Keats e Berlin, 1999). No total, foram identificados até o momento 56 genes responsáveis por surdez não-sindrômica. Entretanto, eles correspondem somente a cerca de metade do total de locos já mapeados, pois muitos locos ainda não tiveram seus genes identificados. A Tabela I lista os 56 genes já conhecidos e a função de seus produtos no processo da audição. 
Tabela I. Genes de surdez não-sindrômica e função dos produtos no processo da audição (modificado de Hilgert e col., 2009a).

\begin{tabular}{lll}
\hline Gene & Loco & Função do produto na audição \\
\hline Herança autossômica recessiva ou dominante & \\
GJB2 & DFNB1/DFNA3A & Homeostase iônica \\
TMC1 & DFNB7/DFNB11/DFNA36 & Função desconhecida \\
TECTA & DFNB21/DFNA8/DFNA12 & Proteína da matriz extracelular \\
MYO7A & DFNB2/DFNA11 & Proteína motora dos estereocílios \\
GJB6 & DFNB1/DFNA3B & Homeostase iônica \\
MYO6 & DFNB37/DFNA22 & Proteína motora dos estereocílios \\
GJB3 & - /DFNA2B & Homeostase iônica \\
COL11A2 & DFNB53/DFNA13 & Proteína da matriz extracelular \\
& & \\
Herança autossômica recessiva & \\
SLC26A4 & DFNB4 & Homeostase iônica \\
MYO15A & DFNB3 & Proteína motora dos estereocílios \\
OTOF & DFNB9 & Exocitose nas vesículas sinápticas das \\
& & células ciliadas internas \\
CDH23 & DFNB12 & Proteína de adesão dos estereocílios \\
TMPRSS3 & DFNB8/10 & Função desconhecida \\
TRIOBP & DFNB28 & Formação do citoesqueleto dos \\
TMIE & DFNB6 & estereocílios \\
PJVK & DFNB59 & Função desconhecida \\
ESPN & DFNB36 & Sinalização de células ciliadas e \\
PCDH15 & DFNB23 & neurônios \\
ESRRB & DFNB35 & Formação do citoesqueleto dos \\
MARVELD2 & DFNB49 & estereocílios \\
LHFPL5 & DFNB67 & Proteína de adesão dos estereocílios \\
CLRC & DFNB16 & Fator de transcrição \\
\hline
\end{tabular}


Tabela I (continuação)

\begin{tabular}{|c|c|c|}
\hline Gene & Loco & Função do produto na audição \\
\hline$R D X$ & DFNB24 & $\begin{array}{l}\text { Formação do citoesqueleto dos } \\
\text { estereocílios }\end{array}$ \\
\hline MYO3A & DFNB30 & Proteína motora dos estereocílios \\
\hline SLC26A5 & DFNB61 & $\begin{array}{l}\text { Motor molecular de células ciliadas } \\
\text { externas }\end{array}$ \\
\hline WHRN & DFNB31 & $\begin{array}{l}\text { Proteína do arcabouço protéico dos } \\
\text { estereocílios }\end{array}$ \\
\hline USH1C & DFNB18 & $\begin{array}{l}\text { Proteína do arcabouço protéico dos } \\
\text { estereocílios }\end{array}$ \\
\hline$O T O A$ & DFNB22 & Proteína da matriz extracelular \\
\hline GRXCR1 & DFNB25 & Função desconhecida \\
\hline LOXHD1 & DFNB77 & Feixe de estereocílios \\
\hline TPRN & DFNB79 & Feixe de estereocílios \\
\hline GPSM2 & DFNB82 & Proteína transmembrânica \\
\hline PTPRQ & DFNB84 & Sinalização celular \\
\hline$H G F$ & DFNB39 & Sinalização celular \\
\hline LRTOMT & DFNB63 & Função desconhecida \\
\hline \multicolumn{3}{|c|}{ Herança autossômica dominante } \\
\hline WFS1 & DFNA6/14/38 & Homeostase iônica \\
\hline KCNQ4 & DFNA2A & Homeostase iônica \\
\hline $\mathrm{COCH}$ & DFNA9 & Proteína da matriz extracelular \\
\hline MYO1A & DFNA48 & Função desconhecida \\
\hline ACTG1 & DFNA20/26 & $\begin{array}{l}\text { Formação do citoesqueleto dos } \\
\text { estereocílios }\end{array}$ \\
\hline$E Y A 4$ & DFNA10 & Fator de transcrição \\
\hline MYH14 & DFNA4 & Função desconhecida \\
\hline$D F N A 5$ & DFNA5 & Função desconhecida \\
\hline POU4F3 & DFNA15 & Fator de transcrição \\
\hline CRYM & & Homeostase iônica \\
\hline TFCP2L3 & DFNA28 & Fator de transcrição \\
\hline МYH9 & DFNA17 & Proteína motora dos estereocílios \\
\hline
\end{tabular}


Tabela I (continuação)

\begin{tabular}{|c|c|c|}
\hline Gene & Loco & Função do produto na audição \\
\hline CCDC50 & DFNA44 & $\begin{array}{l}\text { Formação do citoesqueleto dos } \\
\text { estereocílios }\end{array}$ \\
\hline DIAPH1 & DFNA1 & $\begin{array}{l}\text { Formação do citoesqueleto dos } \\
\text { estereocílios }\end{array}$ \\
\hline MIRN96 & DFNA50 & Regulação da expressão gênica \\
\hline TJP2 & DFNA51 & $\begin{array}{l}\text { Manutenção de diferença de potencial } \\
\text { elétrico }\end{array}$ \\
\hline \multicolumn{3}{|c|}{ Herança ligada ao X } \\
\hline POU3F4 & DFNX2 & Fator de transcrição \\
\hline PRPS1 & DFNX1 & $\begin{array}{l}\text { Metabolismo de purina e biossíntese } \\
\text { de nucleotídeos }\end{array}$ \\
\hline \multicolumn{3}{|c|}{ Herança mitocondrial } \\
\hline MT-RNR1 & 12S RNAr & RNA ribossômico mitocondrial \\
\hline MT-TS1 & $\mathrm{RNAt}^{\mathrm{Ser}(\mathrm{UCN})}$ & RNA transportador mitocondrial \\
\hline
\end{tabular}

\section{I.3.1.1. Herança autossômica recessiva}

Cerca de 80\% dos casos de surdez não-sindrômica apresentam herança autossômica recessiva. As perdas auditivas com esse padrão de herança são geralmente sensorioneurais, de manifestação pré-lingual, de graves a profundas, geralmente atingem todas as frequências e são estacionárias (Keats e Berlin, 1999).

No caso da surdez não-sindrômica tem grande destaque o gene GJB2, no loco DFNB1, relacionado tanto com formas dominantes quanto recessivas de surdez nãosindrômica. Este gene codifica a conexina 26, um membro da família das conexinas, proteínas que são componentes estruturais das junções comunicantes intercelulares do tipo "fenda" (gapjunctions) e às quais se atribui um papel importante em vários processos de transdução auditiva, como a reciclagem dos íons potássio na endolinfa e a troca de metabólitos entre as células de suporte (Mese e col., 2004). Mutações no gene GJB2 podem alterar a função da conexina 26 ao acarretar deficiência no fluxo de potássio e desta forma 
levar à morte celular e consequentemente à perda auditiva, uma vez que níveis elevados de potássio podem afetar a função e a sobrevivência das células de suporte necessárias à audição (Rabionet e col., 2000). O fenótipo mais comum associado a mutações nesse gene é caracterizado por surdez profunda e pré-lingual. Mutações neste gene são responsáveis por até 80\% dos casos de surdez hereditária com padrão de herança autossômico recessivo. A mutação mais frequente é a c.35delG, que requer homozigose para sua manifestação. Trata-se do genótipo mais comum em 75\% dos casos de mutações nesse gene (Wilcox e col., 1999). Por esta razão, mutações no gene GJB2 são alvo de intenso estudo molecular e constituem o primeiro passo na triagem de mutações relacionadas à perda auditiva.

Outro gene de destaque, presente no mesmo loco DFNB1, é o GJB6, o qual codifica outra proteína das junções do tipo "fenda", a conexina 30. Os genes GJB2 e GJB6 estão na mesma região cromossômica, 13q11-12, cerca de 35 kb um do outro e expressam proteínas com 77\% de identidade de sequência entre elas (Pallares-Ruiz e col., 2002). Grandes deleções como a del(GJB6-D13S1830), de cerca de 342 kb, e del(GJB6-D13S1854), de cerca de 309 kb, são encontradas em associação com mutações no gene GJB2, levando à deficiência auditiva (del Castillo e col., 2002; del Castillo e col., 2005). Existe ainda um caso descrito de um paciente portador da mutação p.V84M no gene GJB2 e uma enorme deleção de pelo menos $920 \mathrm{~kb}$ que removeu os genes GJB2 e GJB6 no alelo em trans (Feldmann e col., 2009). Porém, uma porcentagem significativa de portadores de mutações em heterozigose no gene GJB2 não possui nenhuma dessas grandes deleções, o que sugere que devem existir outras mutações não identificadas presentes no loco DFNB1 (Hilgert e col., 2009a).

Mais recentemente, Wilch e col. (2010) descreveram uma nova deleção no loco DFNB1 que evidencia a existência de uma região regulatória em cis que controla a expressão dos genes GJB2 e GJB6. A deleção, de 131,4 kb, e cujo ponto de quebra proximal dista mais de $100 \mathrm{~kb}$ de GJB2 e GJB6, foi encontrada em quatro indivíduos heterozigotos para a mutação c.35delG e que apresentavam níveis reduzidos de expressão do RNAm de ambos os genes do alelo em trans. Outra deleção com tamanho em torno de 200 kb em DFNB1, que não envolve nem GJB2 nem GJB6, foi encontrada em indivíduos heterozigotos para a mutação c.35delG em GJB2, sugerindo novamente que essas deleções 
estejam eliminando um elemento regulatório essencial à expressão de GJB2 na orelha interna (del Castillo e col., 2009).

A pesquisa das deleções em GJB6 está indicada, portanto, em pacientes com surdez, principalmente se apresentarem uma mutação única no gene GJB2.

\section{I.3.1.2. Herança autossômica dominante}

A surdez não-sindrômica de herança autossômica dominante corresponde a 20 25\% dos casos de surdez hereditária, sendo majoritariamente de manifestação pós-lingual, progressiva e sensorioneural. Até o momento não se observou um gene que esteja mais frequentemente associado à surdez com esse tipo de herança, da maneira como ocorre com o gene GJB2 na herança autossômica recessiva. No entanto, os locos com maior número de famílias descritas são o DFNA2A e o DFNA9, onde se localizam respectivamente os genes $\mathrm{KCNQ}^{4}$ e $\mathrm{COCH}$.

\section{I.3.1.3. Herança ligada ao X}

A contribuição da herança ligada ao cromossomo X à surdez hereditária é estimada em 1 a 1,5\%. O loco mais frequentemente associado a casos de surdez com esse tipo de herança é o DFNX2, com surdez do tipo mista e associada à fixação do estribo. Neste loco reside o gene POU3F4, o qual codifica um fator de transcrição (Willems e col., 2000).

\section{I.3.1.4. Herança mitocondrial}

A surdez hereditária de herança mitocondrial está geralmente associada a genes que codificam componentes do aparato de síntese protéica mitocondrial, isto é, RNAs ribossômicos e RNAs transportadores. Existem dois genes principais que foram relacionados à surdez mitocondrial não-sindrômica devidos ao grande número de mutações descritas: o gene MT-RNR1, que codifica a subunidade 12S RNAr, e o MT-TS1, que codifica o RNAt ${ }^{S e r(U C N)}$. A primeira mutação associada à perda auditiva não-sindrômica foi a m.1555A > G no gene $M T$-RNR1, descrita pela primeira vez em uma grande família árabeisraelense por Prezant e col. (1993). Juntamente com a mutação c.35delG do gene GJB2, é uma das mutações mais comuns que causam surdez. Esta mutação também tem sido encontrada em pacientes com perda auditiva após uso de antibióticos aminoglicosídeos 
(Pandya e col., 1997; Estivill e col., 1998). Um estudo realizado por nosso grupo estimou que a mutação m.1555A>G foi responsável por 2\% dos casos de perda auditiva estudados no laboratório (Abreu-Silva e col., 2006).

Outras mutações mitocondriais associadas à surdez não-sindrômica são m.961delTinsC(n), m.1095T $>C$, m.1494C $>$ T no gene MT-RNR1, e as mutações m.7445A $>$ G, m.7472insC, m.7510T $>C$ e m.7511T $>C$ no gene MT-TS1 (revisão em Kokotas e col., 2007). Mutações nesse último gene, como a m.7445A>G e m.7472insC, também já foram descritas em pacientes apresentando outros sinais clínicos, como queratoderma palmoplantar e disfunções neurológicas, respectivamente.

\section{I.3.2. Surdez sindrômica}

A perda de audição pode ocorrer em associação com outros sinais clínicos sendo, nesses casos, chamada de surdez sindrômica. Existem mais de 400 síndromes que incluem a surdez como um de seus sinais clínicos. Algumas das síndromes mais frequentes que apresentam esse distúrbio como um de seus sinais mais característicos são a síndrome de Waardenburg (com defeitos de pigmentação e telecanto - OMIM \#193500), a síndrome de Treacher Collins (com anormalidades craniofaciais - OMIM \#154500), a síndrome de Usher (com retinose pigmentar - OMIM \#276900), a síndrome de Pendred (com bócio OMIM \#274600), a síndrome de Alport (com defeitos renais - OMIM \#301050) e a síndrome branquio-oto-renal (com defeitos craniofaciais e renais - OMIM \#113650).

O quadro sindrômico pode ser causado por um único gene que, quando mutado, causa tanto a surdez quanto os sinais associados (como é o caso das síndromes acima citadas) ou pode ainda resultar de alterações de segmentos maiores de DNA contendo genes de surdez não-sindrômica. Nesse caso, os sinais associados seriam causados por outros genes mapeados no mesmo segmento cromossômico, caracterizando síndromes de genes contíguos. Portanto, a surdez sindrômica também pode ser resultante da deleção de genes contíguos, embora poucos casos tenham sido descritos (Zhang e col., 2007). Alguns exemplos incluem a síndrome de hiperinsulinismo infantil associado a enteropatia, surdez e tubulopatia renal (OMIM \#606528), causada por deleção em 11p contendo os genes USH1C, ABCC8 e KCNJ11 (Bitner-Glindzicz e col., 2000), e a síndrome HDR 
(hipoparatireoidismo, surdez e displasia renal - OMIM \#146255), causada por uma deleção em 10p13-14 (Lichtner e col., 2000).

\section{I.4. Variações no número de cópias e doenças genéticas}

Há muito tempo se sabe que variações no DNA que perturbam a condição diplóide, como deleção ou duplicação de material genômico, podem ter como consequência um fenótipo anormal. Além das alterações cromossômicas detectáveis pela análise citogenética convencional, são conhecidas desde a década de 80 algumas síndromes de deleção ou duplicação submicroscópicas (revisão em Stankiewicz e Lupski, 2010). Por exemplo, a microdeleção em 15q11.2q12 como causa da síndrome de Prader-Willi foi identificada em 1981 (Ledbetter e col., 1981), e em 1991 foi identificada a primeira microduplicação em pacientes com a doença de Charcot-Marie-Tooth tipo 1A (Lupski e col., 1991).

As alterações no número de cópias compreendendo pequenos segmentos, isto é, de $1 \mathrm{~kb}$ a alguns $\mathrm{Mb}$, têm tido grande destaque nos cinco últimos anos, pois se descobriu que elas estão amplamente presentes e dispersas por todo o genoma humano e, portanto, constituem grande fonte de diversidade genética (revisão em Zhang e col., 2009). Esse conhecimento foi possível com o advento e a ampla difusão de modernas ferramentas de investigação do genoma humano, como por exemplo, a técnica de array-CGH (Array-based Comparative Genomic Hybridization). Essa técnica, que estima o número de cópias de DNA simultaneamente em milhares de sequências-alvo do genoma, possibilitou a descoberta dessas extensas variações genômicas estruturais, as quais foram chamadas de CNVs (Copy Number V ariations). O termo CNV foi formalizado por Feuk e col. (2006), que o definiram como um segmento de DNA cujo tamanho varia de $1 \mathrm{~kb}$ a vários Mb e que está presente em número variável de cópias em comparação a um genoma de referência.

A vários mecanismos, como NAHR (Nonalelic Homologous Recombination), NHEJ (Nonhomologous End-Joining), retrotransposição e, mais recentemente, FoSTeS (Fork Stalling and Template Switching), são atribuídas as origens desses rearranjos genômicos e formação das CNVs, que podem ser deleções, duplicações, triplicações e inserções (revisão em Stankiewicz e Lupski, 2010). As CNVs podem englobar parte ou um gene por inteiro, ou 
podem constituir um segmento contendo vários genes ou ainda elementos regulatórios. Por essa razão, acredita-se que muitas delas desempenhem um papel na alteração de funções fisiológicas, podendo contribuir ao desenvolvimento de doenças. As CNVs intragênicas ou que abrangem um único gene podem ter consequências funcionais similares às mutações de ponto patogênicas, enquanto as $\mathrm{CNVs}$ maiores podem compreender múltiplos genes e acarretar síndromes de genes contíguos (revisão em Lee e Scherer, 2010). Alguns exemplos de CNVs relacionadas a doenças de herança mendeliana estão listadas na Tabela II.

Tabela II. Exemplos de CNVs relacionadas a doenças de herança mendeliana (modificado de Zhang e col., 2009).

\begin{tabular}{lllll}
\hline Doença/Síndrome & Loco & Rearranjo & Gene(s) \\
\hline Gaucher & $1 \mathrm{q} 21$ & $\mathrm{del}$ & GBA & \\
Smith-Magenis & $17 \mathrm{p} 11.2$ & $\mathrm{del}$ & $\mathrm{SGC}$ incluindo RAI1 & \\
Potocki-Lupski & $17 \mathrm{p} 11.2$ & $\mathrm{dup}$ & $\mathrm{R} A I 1$ & \\
Charcot-Marie-Tooth tipo 1A & $17 \mathrm{p} 12$ & $\mathrm{dup}$ & PMP22 & \\
DiGeorge/Velo-Cardio-Facial & $22 \mathrm{q} 11.2$ & $\mathrm{del}$ & $\mathrm{SGC}$ incluindo & TBX1, \\
& & & COMT & \\
Pelizaeus-Merzbacher & $\mathrm{Xq} 22.2$ & $\mathrm{del} / \mathrm{dup}$ & PLP1 & \\
Hemofilia A & $\mathrm{Xq} 28$ & inv/del & F8 & \\
Nanismo pituitário & $17 \mathrm{q} 24$ & $\mathrm{del}$ & GH1 & \\
Atrofia muscular espinhal & $5 \mathrm{q} 13$ & $\mathrm{del}$ & SMN1 & \\
\hline
\end{tabular}

Del: deleção; dup: duplicação; inv: inversão; SGC: síndrome de genes contíguos.

O principal mecanismo pelo qual esses rearranjos desencadeiam quadros clínicos é a modificação da dosagem gênica, isto é, quando a região deletada ou duplicada contém um ou mais genes cujos efeitos são sensíveis à dosagem. Outros mecanismos que podem deflagrar fenótipos são a ruptura de regiões codificadoras ou de regiões regulatórias.

As CNVs podem ser responsáveis por defeitos ou doenças esporádicas, doenças de herança mendeliana e também já foram associadas à susceptibilidade de doenças de mecanismo multifatorial. Como exemplos do último caso, tem-se a associação entre o número de cópias e aumento na susceptibilidade à infecção pelo vírus HIV-1/AIDS, à doença de Crohn e a lúpus eritematoso sistêmico (Gonzalez e col., 2005; Fellermann e col., 2006; McCarroll e col., 2008). 
A extensa aplicação nos últimos anos da técnica de array-CGH também demonstrou que genomas de indivíduos aparentemente saudáveis apresentam normalmente centenas de regiões genômicas que variam significantemente em número de cópias (Iafrate e col., 2004; Sebat e col., 2004, Redon e col., 2006). Portanto, existem muitas CNVs que, apesar de englobarem um ou mais genes, não possuem nenhum efeito fenotípico aparente. Não estão claros ainda os mecanismos que levam algumas CNVs a terem um efeito fenotípico enquanto outras parecem não ter significado clínico. Dessa forma, um dos grandes desafios atuais consiste em distinguir as CNVs provavelmente patogênicas daquelas presentes na população geral (isto é, benignas), o que implica na necessidade de um estudo cuidadoso antes de se associar uma CNV à causa ou predisposição a uma determinada doença.

Para auxiliar na interpretação do significado de uma $\mathrm{CNV}$, vários critérios foram propostos. Por exemplo, CNVs de novo são mais prováveis de ser as responsáveis por um determinado fenótipo clínico, ao contrário de uma CNV herdada de um genitor não afetado. Outro critério importante é observar se uma CNV encontrada se sobrepõe a algum rearranjo já catalogado em bancos de dados que compilam CNVs presentes na população geral (como o DGV - Database of Genomic Variants http://projects.tcag.ca/variation/) ou em bancos de dados que compilam CNVs clinicamente relevantes (como o DECIPHER - Database of Chromosomal Imbalance and Phenotype in Humans using Ensembl Resources - http://decipher.sanger.ac.uk). Demais critérios estão listados na Tabela III.

\section{I.5. Técnicas de análise genética de alta resolução: Array-CGH e MLPA}

O mapeamento dos genes constitui uma etapa importante na compreensão da biologia de uma doença genética. A identificação dos genes causadores de uma doença pode tornar possível a realização de testes de diagnóstico para mutações específicas, de suma importância no aconselhamento genético das famílias com a doença (Keats, 2002). 
Tabela III. Principais critérios para a avaliação do significado de uma CNV (Lee e col., 2007).

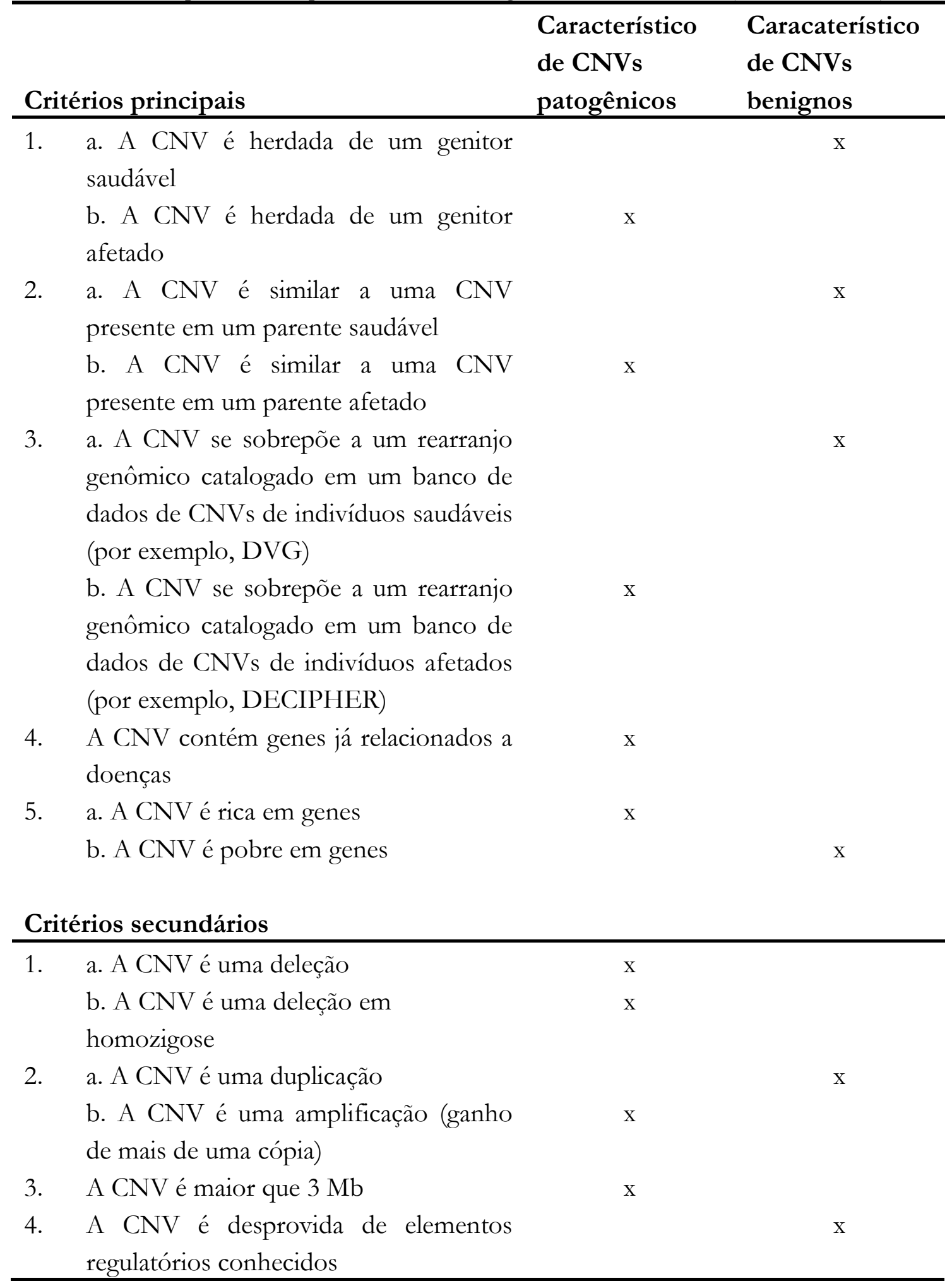


O mapeamento genético é frequentemente realizado por meio de duas estratégias principais: correlações entre alterações cromossômicas associadas a fenótipos anormais e estudos de ligação em grandes famílias apresentando vários indivíduos afetados. $\mathrm{Na}$

primeira estratégia, a presença de alterações cromossômicas associadas a fenótipos anormais sugere que os pontos de quebra, a monossomia ou a duplicação de segmentos possam estar interferindo na expressão de um ou mais genes, o que explicaria a doença observada. Após a identificação do cromossomo portador de uma alteração, faz-se uso de técnicas citogenéticas e moleculares para refinar a localização do rearranjo e deduzir quais são os genes provavelmente envolvidos.

As técnicas citogenéticas clássicas, que incluem bandamento cromossômico, possuem resolução que não permite detectar aberrações menores que 4-10 Mb. Por esta razão, nos últimos anos têm sido desenvolvidas e utilizadas técnicas com maior poder de resolução, tais como FISH (Fluorescent "in situ” Hybridization), CGH (Comparative Genomic Hybridization), array-CGH e MLPA (Multiplex Ligation-dependent Probe Amplification). Por constituírem ferramentas relevantes para a compreensão deste trabalho, as duas últimas técnicas serão explicadas com maior detalhe.

\section{I.5.1. Array-CGH}

A técnica de array-CGH permite analisar alterações em número de cópias (deleções ou duplicações) simultaneamente em milhares de sequências-alvo do genoma e tem como base a técnica de hibridação comparativa do genoma (CGH) previamente descrita por Kallioniemi e col. (1992), a qual utilizava cromossomos metafásicos. A técnica de array-CGH utiliza como alvo de hibridação um conjunto de sondas organizadas em alta densidade em uma lâmina de vidro. A resolução do método é determinada pela distância entre os clones e o tamanho dos fragmentos de DNA clonados. O DNA genômico que se pretende estudar e o da amostra de referência são marcados e os sinais fluorescentes são capturados por um laser scanner. As intensidades de DNA em cada sequência alvo são então quantificadas e permitem estimar ganhos ou perdas de segmentos cromossômicos (Carter e col., 2002; Vissers e col., 2003; Oostlander e col., 2004).

No array-CGH, os fragmentos clonados ou sondas de DNA têm localização previamente conhecida nos cromossomos e, dessa forma, podem ser diretamente 
relacionados com a informação sobre a sequência do genoma humano disponível em bancos de dados. Além da resolução, o array-CGH tem como grande vantagem o fato de utilizar DNA e não metáfases de células em divisão, representando ainda uma metodologia valiosa para detectar alterações genômicas naquelas situações sugestivas de alterações cromossômicas em que anomalias não foram detectadas pela citogenética convencional.

Existem ressalvas na aplicação dessa técnica no caso de distinção de mutações de novo e herdadas. Parte das complicações reside no fato de que as alterações identificadas por array-CGH são calculadas aditivamente (isto é, com base no genoma diplóide) e essa tecnologia não fornece informações sobre rearranjos equilibrados no número de cópias. Por exemplo, uma duplicação aparentemente de novo pode ser, na verdade, produto de um rearranjo equilibrado herdado de um dos genitores, não detectável por array-CGH. Assim, quaisquer alterações detectadas por array-CGH devem preferencialmente ser confirmadas por técnicas moleculares alternativas como FISH, MLPA e PCR quantitativo em tempo real (Rodriguez-Revenga e col., 2007).

\section{I.5.2. MLPA}

A técnica de MLPA foi desenvolvida e descrita por Schouten e col. (2002) e permite detectar alterações no número de cópias em até 50 sequências diferentes de DNA em uma única reação de amplificação. Em outras palavras, essa técnica possibilita a identificação de duplicações e deleções em um grande número de sequências simultaneamente.

A identificação do número de cópias de uma dada sequência é efetuada por meio da hibridação de sondas específicas a essa sequência. A peculiaridade desta técnica está no fato de que não é o DNA genômico que é o alvo da amplificação por PCR, mas sim as sondas que se hibridam ao DNA é que são amplificadas. As sondas de MLPA constituem-se de dois oligonucleotídeos complementares às sequências-alvo de DNA genômico: um oligonucleotídeo sintético curto e um oligonucleotídeo sintético longo contendo um fragmento com sequência derivada de fago M13. Este último contém uma sequência stuffer que varia de tamanho nas diferentes sondas e que possibilita a separação dos diferentes fragmentos por eletroforese em capilar. Inicialmente, as sondas são hibridizadas à sequências-alvo no DNA e em seguida os dois oligonucleotídeos são ligados por uma ligase termostável. Após uma nova desnaturação, o fragmento formado pela junção das sondas é 
então amplificado por PCR (Polymerase Chain Reaction). A reação de PCR é realizada com um único par de primers, que hibrida com todas as sondas. Por fim, os fragmentos são submetidos à eletroforese em capilar. A Fig. 2 ilustra de modo esquemático o princípio básico da reação de MLPA.

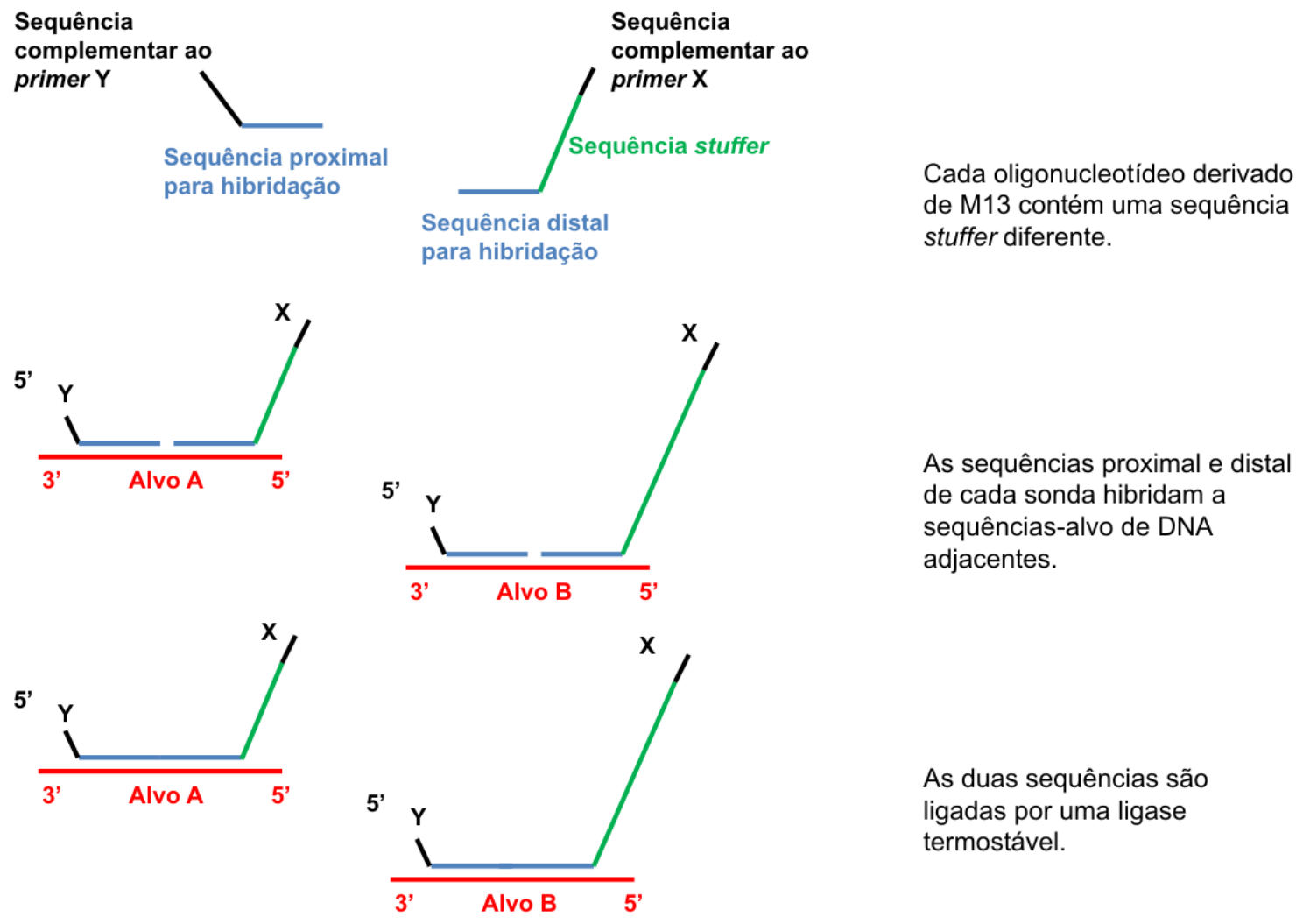

Os produtos de ligação das sondas são amplificados por PCR por um único par de primers.
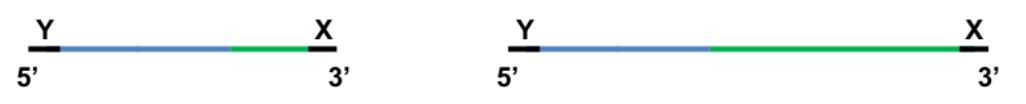

O produto de amplificação de cada sonda possui um tamanho único (130-480 pb).

Fig. 2. Ilustração esquemática da reação de MLPA (modificado de Schouten e col., 2002).

Quando existem patologias onde o gene (ou parte dele) se encontra deletado ou duplicado, as técnicas laboratoriais de PCR e sequenciamento apresentam limitações na detecção devido à amplificação exclusiva do alelo normal na amostra ou da amplificação 
simultânea de vários alelos. Nesse caso, a análise pela técnica de MLPA é uma alternativa apropriada para contornar essas limitações por permitir a identificação de deleções e duplicações. Outras vantagens da técnica de MLPA residem em sua rapidez, simplicidade, baixo custo e disponibilidade de resultados em 24 h para até 96 pacientes.

A empresa que desenvolveu a técnica de MLPA, MRC-Holland (http://www.mrcholland.com/), disponibiliza centenas de kits de sondas para o estudo de diversas doenças genéticas ou síndromes conhecidas, como por exemplo, distrofia muscular de Duchenne, vários tipos de câncer hereditário, síndrome do cromossomo X frágil, doença de CharcotMarie-Tooth, entre outros. Existem também kits para triagem de surdez genética, como por exemplo o kit contendo sondas para os genes GJB2, GJB6, WFS1 e POU3F4 e kit de sondas para os genes $P A X 3$ e $M I T F$, cujas mutações são responsáveis pela síndrome de Waardenburg tipo 2 e tipo 1 e 3 , respectivamente.

A técnica de MLPA possui ainda outras aplicações além da quantificação do número de cópias: também é possível quantificar a expressão gênica (RT-MLPA), detectar metilação (MS-MLPA) e identificar mutações de ponto. No entanto, ela tem sido empregada principalmente nos estudos que visam detectar alterações no número de cópias (Shen e Wu, 2009).

\section{I.6. Justificativa do estudo}

Apesar do notável avanço nos estudos sobre a surdez hereditária, sobretudo nos últimos 20 anos, ainda restam muitos genes a ser identificados como responsáveis por surdez. De fato, existem pelo menos 60 locos mapeados cujo gene ainda não foi identificado, se observarmos o Hereditary Hearing Loss Homepage. Existem ainda casos de surdez não-sindrômica de herança autossômica recessiva em que a segunda mutação não

pôde ser identificada, como ocorre no caso dos genes GJB2 e OTOF, indicando que a segunda mutação poderia se tratar de deleção ou duplicação. Além disso, a grande maioria dos estudos de mapeamento genético da surdez privilegiou a estratégia do estudo de ligação seguido de sequenciamento dos genes candidatos, que mostra principalmente mutações de ponto. Isso indica que a busca de outros mecanismos mutacionais, como 
deleções ou duplicações, foram de certa forma negligenciados nos estudos conduzidos até então. Portanto, a contribuição das CNVs ainda está subestimada no estudo da surdez hereditária.

Existem poucas descrições de alterações no número de cópias já relacionadas à surdez. Dentre os genes de surdez não-sindrômica, o gene GJB6 é o único que possui deleções documentadas, em associação a mutações de ponto no gene GJB2. Outro gene, STRC, de surdez não-sindrômica (loco DFNB16), estava incluído em deleções em homozigose presentes em duas famílias com síndrome de genes contíguos (Avidan e col., 2003; Zhang e col., 2007) e também incluído em uma deleção presente em homozigose em um paciente sindrômico (Knijnenburg e col., 2009). Na síndrome de Waardenburg, Milunsky e col. (2007) estimaram que deleções inteiras ou parciais do gene $P A X 3$ podem explicar aproximadamente $10 \%$ dos casos de indivíduos afetados pela síndrome do tipo 1 ou do tipo 3 que não possuem mutações identificadas por sequenciamento.

Nosso estudo teve sua origem no único trabalho na literatura que teve como abordagem buscar CNVs relacionadas à surdez. Esse trabalho, publicado pela Dra. Ana Lúcia Catelani e colaboradores (Catelani e col., 2009), originou-se de sua tese de doutoramento conduzida no Departamento de Genética e Biologia Evolutiva do Instituto de Biociências da Universidade de São Paulo, sob orientação da Profa. Dra. Carla Rosenberg e com a colaboração da Profa. Dra. Regina Célia Mingroni Netto. Na tese, intitulada "Variação no número de cópias de segmentos de DNA (CNV) em pacientes com surdez sindrômica" (Catelani, 2010), foi investigada a presença de alterações cromossômicas em pacientes com surdez associada a outros sinais clínicos. O principal objetivo desse estudo foi a identificação de novas regiões cromossômicas candidatas a conter genes que venham a esclarecer os fenótipos de surdez dos pacientes. As estratégias utilizadas foram os estudos citogenéticos convencionais e de alta resolução, baseados principalmente na técnica de array-CGH.

A casuística de Catelani (2010) se constituiu de 31 pacientes avaliados no Serviço de Aconselhamento Genético do Laboratório de Genética Humana do IB-USP, com exceção de dois casos examinados em outros institutos. Os pacientes apresentavam surdez associada a outros sinais, cujo quadro clínico não permitiu classificar com certeza em síndrome conhecida. Nesses pacientes, as causas mais comuns de surdez não-sindrômica 
foram excluídas por meio da triagem de rotina das mutações c.35delG e c.167delT no gene GJB2, $\operatorname{del}(G J B 6-\mathrm{D} 13 \mathrm{S1830})$ e $\operatorname{del}(G J B 6-\mathrm{D} 13 \mathrm{~S} 1854)$ no gene GJB6 e a mutação mitocondrial m.1555A>G. Excluídas as mutações mais frequentes, foi realizado o estudo cromossômico dos pacientes (cariótipo), e, nos casos em que o resultado do cariótipo foi normal, o DNA foi investigado para verificação de alterações no número de cópias por meio de array-CGH. Posteriormente, foram realizados ainda experimentos de FISH para validar a presença de deleções ou duplicações identificadas pelo array-CGH e também para investigar a presença de possíveis rearranjos nos genitores.

O trabalho de Catelani (2010) permitiu a detecção de algumas regiões cromossômicas rearranjadas e indicou alguns genes candidatos à surdez dentro dos rearranjos considerados como mais relevantes. Tivemos como proposta dar continuidade aos achados de Catelani, procurando identificar quais genes nesses rearranjos poderiam ter correlações mais evidentes com a surdez. No entanto, selecionamos mais genes candidatos além de alguns já apontados pelos rearranjos detectados no trabalho de Catelani (2010).

Nosso estudo pode indicar novos genes relacionados à surdez, possibilitando que sejam investigados na grande casuística de pacientes com surdez estudada em nosso laboratório. Esse estudo poderá também, no futuro, ter aplicações no diagnóstico precoce e, principalmente, no aconselhamento genético das famílias dos afetados. 


\section{OBJETIVO}




\section{OBJETIVO}

O objetivo deste estudo foi identificar novos genes relacionados à manifestação de surdez sindrômica ou não-sindrômica, por meio da identificação de variações no números de cópias em genes candidatos. Esses genes candidatos foram selecionados, principalmente, a partir de regiões cromossômicas comprometidas por rearranjos presentes em pacientes com surdez sindrômica detectados por array-CGH.

As etapas executadas para atingir o objetivo foram:

i. Seleção de genes candidatos;

ii. Construção de sondas sintéticas de MLPA para cada gene candidato;

iii. Triagem de microdeleções e microduplicações nos genes candidatos por meio da técnica de MLPA em uma casuística de 163 pacientes com surdez sindrômica ou não-sindrômica;

iv. Triagem por MLPA das microdeleções e microduplicações detectadas nos pacientes em uma amostra controle, composta por 189 indivíduos ouvintes, para avaliar se as alterações também estavam presentes na população normal;

v. Estudos de segregação nas famílias dos pacientes com alterações detectadas;

vi. Investigação de mutações de ponto nos genes que se revelaram como deletados ou duplicados entre os pacientes da casuística, para verificar se outras mutações ocorriam nesses indivíduos. 


\section{CASUÍsticA E MÉTOdos}




\section{CASUÍ́STICA E MÉTODOS}

\section{III.1. Casuística}

A casuística se compõe de 163 pacientes não aparentados com perda auditiva de graus diversos de manifestação, avaliados no Serviço de Aconselhamento Genético do Laboratório de Genética Humana, Centro de Estudos do Genoma Humano, Departamento de Genética e Biologia Evolutiva, Instituto de Biociências da Universidade de São Paulo (IB-USP). Esses pacientes foram encaminhados por instituições como a Divisão de Educação e Reabilitação de Distúrbios da Comunicação da Pontifícia Universidade Católica de São Paulo (DERDIC/PUC-SP), Hospital das Clínicas da Faculdade de Medicina da Universidade de São Paulo (HC-FMUSP), incluindo o Instituto da Criança (ICr), e Universidade Federal de São Paulo (UNIFESP), entre outras.

Todos os indivíduos portadores de distúrbios de audição ou seus responsáveis foram entrevistados e assinaram o termo de consentimento formal para o exame e a utilização dos dados para pesquisa. Este projeto e seus termos de consentimento livre e esclarecido foram aprovados pelo Comitê de Ética em Pesquisa - Seres Humanos (CEP) do IB-USP. Cópias dos termos de consentimento para menor e maior de idade e do parecer favorável do CEP encontram-se disponíveis na seção “Anexos". Parte dos pacientes ou responsáveis assinou outros termos de consentimento, na vigência de projetos correlatos de nosso laboratório, igualmente aprovados pelo CEP, mas que já foram finalizados.

A casuística de 163 pacientes se dividiu em dois grupos:

- 74 pacientes com surdez associada a outros sinais (surdez sindrômica) que não puderam ser classificados em síndromes conhecidas, casos isolados na grande maioria, incluindo os 31 que haviam sido previamente estudados por Catelani (2010). A inclusão desses 31 pacientes em nosso estudo se justifica pelo fato da plataforma de array-CGH utilizada possuir em torno de 3.500 fragmentos clonados de DNA 
espaçados a cada $1 \mathrm{Mb}$. Assim, seria possível que houvesse alterações ainda menores nesses espaços que outras técnicas mais refinadas, como o MLPA, poderiam detectar. Os sinais clínicos mais comuns entre os observados nessa amostra incluíam retardo mental, anomalias cardíacas, defeitos de membros, entre outros;

- 89 propósitos com surdez não-sindrômica pertencentes a famílias nas quais segrega surdez de provável herança autossômica dominante (41 casos) ou recessiva (48 casos). São famílias cujo diagnóstico molecular até então permanece inconclusivo.

Todos os 163 pacientes da casuística já haviam sido submetidos à triagem de rotina no nosso laboratório das mutações c.35delG e c.167delT no gene GJB2, as deleções $\operatorname{del}(G J B 6-\mathrm{D} 13 \mathrm{S1830})$ e $\operatorname{del}(G J B 6-\mathrm{D} 13 \mathrm{S1854})$ no gene GJB6 e a mutação mitocondrial m.1555A > G no gene $M T-R N R 1$, as quais foram excluídas como causas da surdez nesses indivíduos.

Estudamos também uma amostra controle constituída por 189 indivíduos ouvintes da população geral, de diversas origens geográficas. Dessa amostra, 101 são indivíduos expostos a ruído em seu ambiente de trabalho e que possuem resultado normal de avaliação audiológica. Esses indivíduos fizeram parte do grupo controle do estudo de Abreu-Silva e col. (2010), sobre perda auditiva induzida por ruído. O restante da amostra controle é composto por indivíduos que estudam ou trabalham no IB-USP, moradores do Conjunto Residencial da Universidade de São Paulo (CRUSP) e doadores de sangue da Fundação Pró-Sangue Hemocentro de São Paulo, além de outros. Todos os que concordaram em participar do estudo foram entrevistados quanto a queixas de problemas auditivos e à existência de deficientes auditivos na família e também assinaram termo de consentimento livre e esclarecido.

\section{III.2. Métodos}

\section{III.2.1. Seleção de genes candidatos}

No trabalho de Catelani (2010), foram detectadas por array-CGH alterações genômicas em oito dos 31 pacientes. A Tabela IV descreve as principais informações acerca dos oito pacientes com rearranjos. 
Tabela IV. Achados clínicos dos pacientes com rearranjos genômicos detectados por array-CGH (modificado de Catelani e col., 2009).

\begin{tabular}{|c|c|c|c|c|c|c|c|}
\hline Paciente & DECIPHER & Idade & Gênero & $\begin{array}{l}\text { Perda } \\
\text { auditiva }^{a}\end{array}$ & Achados clínicos & Rearranjo & Herança \\
\hline 1 & USP00002396 & $8 \mathrm{a} 5 \mathrm{~m}$ & $\mathrm{M}$ & $\mathrm{SN}, \mathrm{BL}, \mathrm{PF}$ & $\begin{array}{l}\text { Baixa estatura, atrofia do nervo ótico, rins em ferradura, } \\
\text { criptorquidia, hérnia umbilical, braquidactilia, polegar alargado. }\end{array}$ & $\operatorname{del}(1)(\mathrm{q} 23.3 \mathrm{q} 25.2)$ & de novo \\
\hline 2 & USP00248386 & $11 \mathrm{a} 9 \mathrm{~m}$ & $\mathrm{M}$ & $\mathrm{SN}, \mathrm{BL}, \mathrm{PF}$ & $\begin{array}{l}\text { Retardo mental, baixa estatura, heterocromia de íris, prega } \\
\text { epicântica, nariz grosso, orelha com implantação baixa e defeito } \\
\text { no lóbulo, hiperqueratose palmar. }\end{array}$ & $\operatorname{dup}(2)(\mathrm{q} 22.2 \mathrm{q} 23.3)$ & de novo \\
\hline 3 & USP00001448 & $6 \mathrm{a} 5 \mathrm{~m}$ & $\mathrm{~F}$ & $\mathrm{SN}, \mathrm{BL}, \mathrm{PF}$ & $\begin{array}{l}\text { Craniosinostose, fronte proeminente, má-oclusão dentária, } \\
\text { defeitos cardíacos congênitos }{ }^{\mathrm{b}} \text { (DSV, DSA, DAP), braquidactilia, } \\
\text { clinodactilia do } 5^{\circ} \text { dedo, háluxes alargados . }\end{array}$ & $\operatorname{dup}(6)(\mathrm{p} 25.2 \mathrm{p} 25.3)$ & de novo \\
\hline 4 & USP00002389 & $2 \mathrm{a} 5 \mathrm{~m}$ & $\mathrm{~F}$ & $\begin{array}{l}\text { SN, BL, } \\
\text { MG }\end{array}$ & $\begin{array}{l}\text { Retardo de desenvolvimento, defeito cardíaco congênito (DAP), } \\
\text { dentes inferiores pequenos e espaçados. }\end{array}$ & $\operatorname{del}(11)(\mathrm{q} 13.2 \mathrm{q} 13.4)$ & de novo \\
\hline 5 & USP00002394 & $12 \mathrm{a} 6 \mathrm{~m}$ & $\mathrm{M}$ & $\begin{array}{l}\mathrm{SN}, \mathrm{BL} \\
\mathrm{MD}\end{array}$ & $\begin{array}{l}\text { Retardo mental, baixa estatura, microcefalia, ponte nasal elevada, } \\
\text { prega epicântica, palato alto e estreito, orelhas com lóbulos } \\
\text { grandes, pectus excavatum discreto, clinodactilia de } 5^{\circ} \text { dedo } \\
\text { bilateral, pes cavus. }\end{array}$ & $\operatorname{dup}(2)(q 12.3 q 12.3)$ & Materna \\
\hline 6 & USP00002392 & $2 \mathrm{a} 5 \mathrm{~m}$ & $\mathrm{M}$ & $\begin{array}{l}\mathrm{SN}, \mathrm{BL} \\
\mathrm{GR}(\mathrm{E}) \\
\mathrm{MD}(\mathrm{D})\end{array}$ & $\begin{array}{l}\text { Retardo de desenvolvimento, sinófre, braquicefalia discreta, } \\
\text { almofadas digitais, clinodactilia de } 5^{\circ} \text { dedo bilateral. }\end{array}$ & $\operatorname{del}(4)(q 23 q 24)$ & Paterna \\
\hline 7 & USP00002391 & $5 \mathrm{a} 3 \mathrm{~m}$ & $\mathrm{M}$ & $\begin{array}{l}\mathrm{SN}, \mathrm{BL} \\
\mathrm{MD}(\mathrm{E}) \\
\mathrm{GR}(\mathrm{D})\end{array}$ & $\begin{array}{l}\text { Retardo de desenvolvimento, hipertelorismo, orelhas } \\
\text { proeminentes, pectus excavatum, escroto em cachecol, polidactilia } \\
\text { pós-axial ( } 5^{\circ} \text { dedo) à esquerda, braquidactilia. }\end{array}$ & $\operatorname{del}(7)(\mathrm{q} 31.1 \mathrm{q} 31.1)$ & Materna \\
\hline 8 & USP00002390 & $4 \mathrm{a} 7 \mathrm{~m}$ & M & $\begin{array}{l}\mathrm{SN}, \mathrm{BL} \\
\mathrm{PF}(\mathrm{E}) \\
\mathrm{MD}(\mathrm{D})\end{array}$ & $\begin{array}{l}\text { Retardo de desenvolvimento, palato alto e estreito, inclinação } \\
\text { antimongolóide das fissuras palpebrais, orelhas displásicas, } \\
\text { hiperextensibilidade articular, sindactilia }\left(3^{\circ} / 4^{\circ}\right) \text {. }\end{array}$ & $\operatorname{del}(15)(q 15.3 q 15.3)$ & Materna \\
\hline
\end{tabular}


Todos os pacientes com alterações foram cadastrados no banco de dados DECIPHER, no qual são registradas informações como a localização, posição e provável extensão do rearranjo, além dos achados clínicos e demais informações relevantes de cada paciente. Esses dados podem ser exportados e visualizados no Ensembl (http://www.ensembl.org), cuja apresentação facilita a visualização dos genes contidos na região do rearranjo.

Desconsideramos para o nosso estudo o caso do Paciente 1, que apresentou uma grande deleção de no mínimo $14 \mathrm{Mb}$ em 1q23.3q25.2, cuja região abrange aproximadamente 100 genes conhecidos. Isto tornaria difícil selecionar quais deles estariam de fato contribuindo para explicar seu fenótipo. Além disso, essa região engloba o loco DFNA7, fato que por si só já explicaria a surdez do paciente. Por conseguinte, utilizamos informações sobre os sete pacientes restantes com alterações detectadas por array-CGH.

Para a seleção de genes candidatos, realizamos um levantamento dos genes contidos nas regiões alteradas e também a elas adjacentes, uma vez que as sondas do array-CGH possuíam um espaçamento de $1 \mathrm{Mb}$. Dessa forma, poderia haver mais genes também comprometidos próximos a essas sondas. Os principais critérios de seleção foram: inclusão de genes que codificam proteínas que podem ser funcionalmente relacionadas à fisiologia do sistema auditivo (por exemplo, proteínas transmembrânicas, canais iônicos, fatores de transcrição etc) e a seleção de genes cujo padrão de expressão inclui orelha ou tecido nervoso. O levantamento foi realizado principalmente nos bancos de dados Entrez Gene (http://www.ncbi.nlm.nih.gov/gene) e OMIM (http://www.ncbi.nlm.nih.gov/omim) para a descrição das características e/ou prováveis funções de cada gene; e em bancos de dados contendo informações sobre ESTs (Expressed Sequence Tags) como UniGene (http://www.ncbi.nlm.nih.gov/UniGene), Morton Human Fetal Cochlea cDNA Library EST Data (http://www.brighamandwomens.org/bwh_hearing/human-cochlear-ests.aspx) e Genatlas (http://genatlas.medecine.univ-paris5.fr/), para se pesquisar o padrão de expressão em tecidos.

A Tabela $\mathrm{V}$ apresenta os genes candidatos selecionados a partir das informações dos sete pacientes e outros dados da literatura, com a justificativa de seleção em cada caso. 
Tabela V. Genes candidatos selecionados a partir de rearranjos detectados por array-CGH e dados da literatura. Os tamanhos estimados (em Mb) se referem aos resultados de array-CGH de $1 \mathrm{Mb}$.

\begin{tabular}{|c|c|c|c|c|c|c|c|}
\hline \multirow[t]{2}{*}{ Paciente } & \multirow[t]{2}{*}{ Rearranjo } & \multicolumn{2}{|c|}{ Tamanho estimado $(\mathrm{Mb})$} & \multirow{2}{*}{$\begin{array}{l}\text { Genes } \\
\text { selecionados }\end{array}$} & \multicolumn{2}{|c|}{ Inclusão no rearranjo } & \multirow[t]{2}{*}{ Justificativa de seleção } \\
\hline & & Mínimo & Máximo & & Certa & Possível & \\
\hline 2 & $\begin{array}{l}\text { Duplicação de novo } \\
\text { em } 2 \mathrm{q} 22.2 \mathrm{q} 23.3\end{array}$ & 6,19 & 7,19 & $\mathrm{KIF5C}$ & $\mathrm{x}$ & & $\begin{array}{l}\text { Codifica uma proteína da família das cinesinas, com } \\
\text { alto nível de expressão em tecido cerebral. }\end{array}$ \\
\hline \multirow[t]{3}{*}{3} & $\begin{array}{l}\text { Duplicação de novo } \\
\text { em } 6 \mathrm{p} 25.3 \mathrm{p} 25.2\end{array}$ & 1,17 & 3,08 & FOXQ1 & $\mathrm{x}$ & & Codifica um fator de transcrição. \\
\hline & & & & $\begin{array}{l}\text { FOXF2 } \\
\text { FOXC1 }\end{array}$ & $\begin{array}{l}\mathrm{x} \\
\mathrm{x}\end{array}$ & & $\begin{array}{l}\text { Codifica um fator de transcrição. } \\
\text { Codifica um fator de transcrição e possui expressão } \\
\text { na cóclea. }\end{array}$ \\
\hline & & & & $\begin{array}{l}\text { MYLK4 } \\
\text { TUBB2A }\end{array}$ & $\begin{array}{l}\mathrm{x} \\
-\end{array}$ & - & $\begin{array}{l}\text { Perfil de ESTs mostra expressão na orelha. } \\
\text { Perfil de ESTs inclui orelha e tecido nervoso. Porém, } \\
\text { refinamento posterior por oligoarrays de } 105 \mathrm{k} \\
\text { mostrou que o gene não está incluído no rearranjo. }\end{array}$ \\
\hline \multirow[t]{5}{*}{4} & $\begin{array}{l}\text { Deleção de novo em } \\
11 \mathrm{q} 13\end{array}$ & 2,24 & 3,05 & TPCN2 & $\mathrm{x}$ & & Codifica um putativo canal iônico cátion-seletivo. \\
\hline & & & & FGF19 & $\mathrm{x}$ & & Necessário ao desenvolvimento da orelha interna. \\
\hline & & & & FGF3 & $\mathrm{x}$ & & $\begin{array}{l}\text { Estudos de ortólogos desse gene em galinha e } \\
\text { camundongo sugeriram papel na formação da orelha } \\
\text { interna. }\end{array}$ \\
\hline & & & & CTTN & $\mathrm{x}$ & & $\begin{array}{l}\text { O produto do órtologo murino se liga à actina e } \\
\text { interage com Shank } 2 \text {. }\end{array}$ \\
\hline & & & & SHANK2 & $\mathrm{x}$ & & Possui expressão na cóclea. \\
\hline
\end{tabular}


Tabela V (continuação)

\begin{tabular}{|c|c|c|c|c|c|c|c|}
\hline \multirow[t]{2}{*}{ Paciente } & \multirow[t]{2}{*}{ Rearranjo } & \multicolumn{2}{|c|}{ Tamanho estimado (Mb) } & \multirow{2}{*}{$\begin{array}{l}\text { Genes } \\
\text { selecionados }\end{array}$} & \multicolumn{2}{|c|}{ Inclusão no rearranjo } & \multirow[t]{2}{*}{ Justificativa de seleção } \\
\hline & & Mínimo & Máximo & & Certa & Possível & \\
\hline 5 & $\begin{array}{l}\text { Duplicação em } \\
\text { 2q12.3 herdada de } \\
\text { mãe normal }\end{array}$ & 0,21 & 1,47 & SLC5A7 & & $\mathrm{x}$ & $\begin{array}{l}\text { Codifica um transportador da colina, precursor do } \\
\text { neurotransmissor acetilcolina. }\end{array}$ \\
\hline \multirow[t]{2}{*}{6} & $\begin{array}{l}\text { Deleção em 4q24 } \\
\text { herdada de pai } \\
\text { normal }\end{array}$ & 0,46 & 2,07 & $E M C N$ & $\mathrm{x}$ & & Possui expressão na cóclea. \\
\hline & & & & РPР3СA & & $\mathrm{x}$ & Possui expressão na cóclea. \\
\hline \multirow[t]{2}{*}{7} & $\begin{array}{l}\text { Deleção em 7q31.1 } \\
\text { herdada de mãe } \\
\text { normal }\end{array}$ & 0,16 & 0,79 & $I M M P 2 L$ & $\begin{array}{l}\text { Porção } \\
\text { terminal }\end{array}$ & & $\begin{array}{l}\text { Codifica uma proteína mitocondrial e possui } \\
\text { expressão na cóclea. }\end{array}$ \\
\hline & & & & LRRN3 & & $\mathrm{x}$ & Possui expressão na cóclea e em tecido cerebral. \\
\hline \multirow[t]{2}{*}{8} & $\begin{array}{l}\text { Deleção em } \\
15 q 15.3 \text { herdada de } \\
\text { mãe normal }\end{array}$ & 0,17 & 1,35 & $M A P 1 A$ & & $\mathrm{x}$ & $\begin{array}{l}\text { Ikeda e col. (2002) identificaram o gene Map1 a como } \\
\text { o QTL moth1 (modifier of tubby bearing-1), o qual afeta a } \\
\text { audição em camundongos tubby. }\end{array}$ \\
\hline & & & & STRC & $\mathrm{x}$ & & $\begin{array}{l}\text { É expresso nos estereocílios e já foi relacionado à } \\
\text { surdez (DFNB16). }\end{array}$ \\
\hline Literatura & - & - & - & TMC1 a TMC8 & - & - & $\begin{array}{l}\text { TMC1 possui expressão na cóclea e já foi } \\
\text { relacionado à surdez (DFNB7/11, DFNA36). }\end{array}$ \\
\hline
\end{tabular}


Os cinco genes candidatos selecionados a partir do Paciente 4 já haviam sido descritos como candidatos, entre outros, a um loco de surdez de herança autossômica recessiva, nomeado como DFNB63, por três grupos de pesquisadores que estudaram famílias de diferentes nacionalidades com surdez não-sindrômica (Tlili e col., 2006; Khan e col., 2007; Kalay e col., 2007). Portanto, esse fato reforçou a escolha dos cinco genes da região 11q13 como candidatos para estudo. Entretanto, após este processo de seleção de genes candidatos, foi publicado um trabalho no fim de 2008 em que o gene LRTOMT foi descrito como o responsável pela surdez nesse loco (Ahmed e col., 2008).

Além dos 18 genes selecionados a partir das informações advindas dos sete pacientes, incluímos em nossa seleção os oito genes da família TMC, ou seja, de TMC1 a TMC8. Essa inclusão teve como base dois casos de pacientes que apresentaram uma provável deleção de novo em 16p12.3, cujos resultados aguardavam confirmação por FISH à época de nossa etapa de seleção de genes candidatos. Essa região compreende os genes TMC5 e TMC7, pertencentes a uma família que codifica proteínas transmembrânicas, a família TMC. A essa família gênica pertence o gene TMC1, de função ainda desconhecida e que se expressa na cóclea. Mutações em TMC1 (DFNB7/11, DFNA36) foram associadas com surdez pré e pós-lingual progressiva (Kurima e col., 2002; Kitajiri e col., 2007). Assim, decidimos incluir todos os genes da família TMC na lista de genes candidatos. Mais tarde, porém, as deleções dos pacientes não foram confirmadas por FISH, mas optamos por manter os genes dessa família levando em conta as informações colhidas da literatura. Portanto, selecionamos no total 26 genes candidatos para estudo.

\section{III.2.2. Construção das sondas in-house de MLPA}

A empresa MRC-Holland (Amsterdam, The Netherlands) disponibiliza vários kits comerciais de sondas para várias doenças genéticas ou síndromes específicas, com sondas de genes conhecidos para uma determinada doença. No entanto, é possível desenhar sondas in-house ou sintéticas de MLPA nos casos em que não existem sondas comerciais para uma certa doença ou gene que se queira estudar. Assim, a construção de sondas inhouse de MLPA para cada um dos genes candidatos selecionados foi fundamental ao desenvolvimento deste estudo. 
Em linhas gerais, na construção de um conjunto de sondas comercial ou in-house de MLPA, as sondas são desenhadas de modo que cada uma delas tenha um tamanho único, distinto das demais. Essa diferença no tamanho das sondas será refletida no tamanho dos produtos amplificados, que serão separados por eletroforese em capilar. Cada sonda é formada por dois oligonucleotídeos com sequências que irão hibridar com o DNA genômico alvo. Essas sequências, denominadas proximal e distal, devem necessariamente ser adjacentes uma a outra. Na porção 5' da sequência proximal e na porção 3' da sequência distal são adicionadas as sequências complementares ao par de primers comum, que vai amplificar todas as sondas: 5' GGG TTC CCT AAG GGT TGG A 3' e 5' TCT AGA T'TG GAT CTT GC TGG CGC 3', respectivamente. Adicionalmente, a extremidade 5’ da sequência distal deve ser fosforilada, de modo a permitir a ação da enzima ligase, que irá ligar as sequências proximal e distal. Somente as sondas que estiverem ligadas serão amplificadas exponencialmente por PCR. Portanto, uma sonda de MLPA consiste de dois oligonucleotídeos e cada um deles contém uma sequência que irá hibridar ao DNA mais a sequência complementar a um dos primers.

As sondas comerciais diferem basicamente das in-house pelo fato de um de seus oligonucleotídeos ser derivado de fago M-13 e conter uma sequência stuffer, a qual permite modular o tamanho final e construir sondas mais longas. Desta forma, torna-se possível a inclusão de até 50 sondas em um mesmo kit. Por sua vez, as sondas in-house, por serem constituídas de dois oligonucleotídeos sintéticos, são limitadas no seu tamanho total, que deve estar entre 84 a 140 nt, tamanho esse que inclui o comprimento das sequências que serão complementares ao par de primers. Uma vez que a diferença de tamanho entre os produtos amplificados deve ser de pelo menos $4 \mathrm{nt}$, cada conjunto de sondas comporta, somente, no máximo em torno de 13 sondas. Como nossa seleção de genes candidatos continha 26 genes no total, construímos dois conjuntos de sondas, nomeados como MLPA-A e MLPA-B, com uma sonda para cada gene. A Fig. 3 apresenta o esquema de uma sonda in-house de MLPA e seus componentes. 


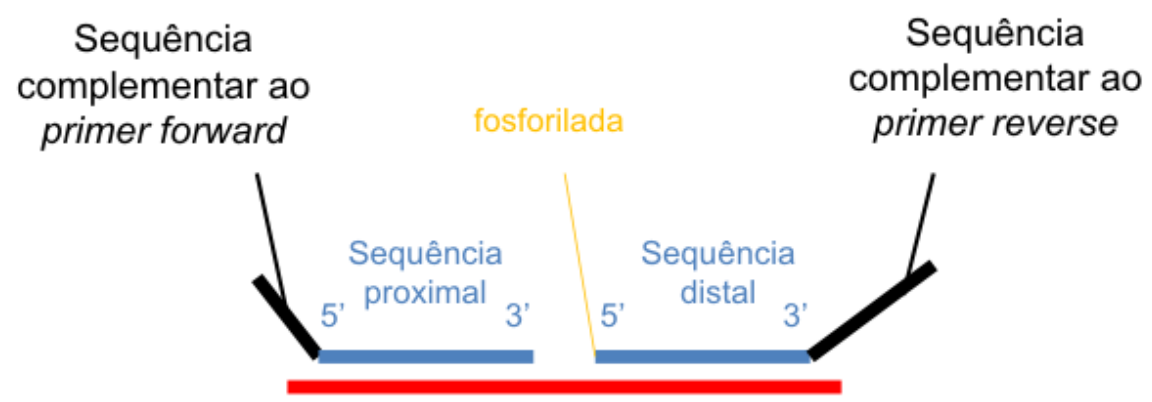

Sequência alvo de DNA

Fig. 3. Esquema representando uma sonda in-house de MLPA e seus componentes. A barra em vermelho representa a sequência alvo de DNA à qual se hibridam as duas sequências, proximal e distal, representadas por barras em azul. As barras pretas adjacentes às barras azuis correspondem às sequências complementares ao par de primers. A extremidade 5' da sequência distal deve ser fosforilada para permitir a ligação entre as duas sequências.

Cada gene teve éxons ou íntrons selecionados com o auxílio de ferramentas disponíveis no UCSC Genome Browser (http://genome.ucsc.edu/). Utilizamos como genoma de referência o NCBI36/hg18 de Março de 2006. As sequências de éxons ou íntrons de cada gene foram exportadas para o formato FASTA a fim de serem lidas pelo software MELTingeny 1.0 (Ingeny International, Goes, The Netherlands) utilizado para desenhar as sondas. Cada sonda foi desenhada de maneira que suas sequências, proximal e distal, ficassem contíguas e totalizassem o tamanho pré-definido entre 42 a 98 nt, tamanho que não inclui as sequências complementares ao par de primers. Para o desenho de cada sonda, alguns critérios foram seguidos, dentre os quais destacamos: a sequência alvo deveria preferencialmente estar em região codificadora (éxon), com conteúdo GC aproximadamente de 50\%; a temperatura de melting de cada sequência deveria estar aproximadamente entre $70{ }^{\circ} \mathrm{C}$ e $75^{\circ} \mathrm{C}$; as sequências deveriam ser preferencialmente únicas para evitar hibridação cruzada; e dever-se-iam evitar sequências contendo SNPs, em especial na região de ligação, pois sua presença pode levar à ocorrência de falso-positivos para deleção em heterozigose.

Somente a sonda para o gene STRC não foi desenhada por nós, pois já havia disponíveis sequências de sondas para este gene que foram desenhadas pelo pesquisador holandês Jeroen Knijnenburg, da Leiden University Medical Center (Knijnenburg e col., 2009). Assim, ao final, as 26 sondas desenhadas foram distribuídas nos conjuntos MLPA-A 
e MLPA-B, cujas sequências nucleotídicas estão indicadas nas Tabelas VI e VII, respectivamente. Todos os oligonucleotídeos sintéticos foram manufaturados pela Invitrogen (Carlsbad, California, USA).

No caso de genes em que foram detectadas alterações, novas sondas para IMMP2L, STRC e TMC6 foram desenhadas para validar os resultados iniciais observados. As novas sondas foram desenhadas a partir de regiões diferentes das que foram utilizadas como alvo de hibridação da primeira sonda. Sequências nucleotídicas das novas sondas estão indicadas na Tabela VIII. No caso de STRC, a sequência de sua sonda foi obtida do estudo de Knijnenburg e col. (2009).

Um protocolo mais detalhado sobre a construção de sondas sintéticas de MLPA encontra-se disponível na página eletrônica da MRC-Holland (http://www.mlpa.com).

\section{III.2.3. Extração de DNA}

As amostras de sangue periférico de cada indivíduo da casuística tiveram o DNA extraído com fenol e clorofórmio, segundo protocolo de rotina do Laboratório de Genética Humana. Parte das amostras foi extraída no aparelho Autopure LS (Gentra Systems, Minneapolis, Minnesota, USA). Posteriormente, cada amostra de DNA foi quantificada pelo espectrofotômetro NanoDrop ND-1000 (NanoDrop Technologies, Rockland, Delaware, USA).

\section{III.2.4. A reação de MLPA e a interpretação dos resultados}

O protocolo para a execução da reação de MLPA encontra-se disponível na página eletrônica da MRC-Holland (http://www.mlpa.com). O protocolo seguido foi o mesmo empregado para os kits comercializados pela empresa, com a diferença de que se deve utilizar DNA à concentração de $400 \mathrm{ng}$ no caso das sondas sintéticas. Utilizamos o kit SALSA MLPA EK-1 (MRC-Holland), que contém todos os reagentes necessários à reação.

A reação de MLPA foi iniciada pela desnaturação de $8 \mu$ de DNA a $98{ }^{\circ} \mathrm{C}$ por 5 min. Em seguida, foram adicionados $3 \mu \mathrm{l}$ de mix contendo as sondas em cada amostra, dando início à etapa de hibridação: 1 min a $95^{\circ} \mathrm{C}$ seguido de incubação a $60^{\circ} \mathrm{C}$ por $16 \mathrm{~h}$. A etapa subsequente consistiu na ligação das sondas proximais e distais, com a adição da 
Tabela VI. Conjunto MLPA-A, com as sondas correspondentes aos genes, região cromossômica, sequências proximal e distal para hibridação e posição genômica de cada sonda (da extremidade 5' da sequência proximal até a extremidade 3 ' da sequência distal).

\begin{tabular}{|c|c|c|c|c|}
\hline \multirow{2}{*}{ Gene } & \multirow{2}{*}{ Região } & \multicolumn{2}{|c|}{ Sequências para hibridação $\left(5^{\prime} \rightarrow 3^{\prime}\right)$} & \multirow{2}{*}{ Posição genômica } \\
\hline & & Proximal & Distal & \\
\hline \multirow[t]{2}{*}{ CTTN } & $11 \mathrm{q} 13$ & CGTGCAGGCCGACCGAGTAGACAAGAGCGCG & TACCAGGGCAAGACGGAGAAGCACGAGTCAC & $69,940,798-69,940,883$ \\
\hline & & GTGGGCTTCGAC & AGAGAGGTGGGG & \\
\hline \multirow[t]{2}{*}{ FGF3 } & $11 \mathrm{q} 13$ & CCACGAAGTACCACСTCCAGCTGCACCCGAGCG & AGCCTGGAGAACAGCGCCTACAGTGAGTGCC & $69,342,394-69,342,487$ \\
\hline & & GCCGCGTCAACGGC & GGACGCTGCGGGGCCC & \\
\hline \multirow[t]{2}{*}{ FOXC1 } & $6 \mathrm{p} 25$ & CGCCCCGCCGCCGCACCATAGCCAGGGCTTCA & ACATCATGACGTCGCTGCGGGGGTCGCCGCA & $1,556,573-1,556,654$ \\
\hline & & GCGTGGACA & GAGCGCGGCC & \\
\hline FOXQ1 & $6 \mathrm{p} 25$ & TGCGCAAGCCCTTCCGCAGCCGCCGCCTC & AGGGACACGGCCCCCGGGACGACGCT'TCA & $1,258,769-1,258,826$ \\
\hline$I M M P 2 L$ & $7 \mathrm{q} 31$ & TGGCGGTGCCTGTGGCAGTGA & CTTTCTTGGATCGGGTCGCCT & $110,948,678-110,948,637$ \\
\hline KIF5C & $2 \mathrm{q} 23.1$ & AAGGAGAACGCCATGCGGGACCGTA & AGCGCTACCAGCAGGAGGTGGATCG & $149,555,003-149,575,052$ \\
\hline LRRN3 & $7 \mathrm{q} 31$ & TGGAGCAGCTGCGAGTGCTACAT & CTTGGCTGTCTGAAGCGATTGGC & $110,518,314-110,518,359$ \\
\hline \multirow[t]{2}{*}{$M A P 1 A$} & $15 q 15.3$ & CAGCGCAAAGTGGCAGAGCTAGAGGAGGAGC & TCCCAGGGCTCTAGCAGTTACAGCGACTGGG & $41,601,270-41,601,335$ \\
\hline & & AG & TG & \\
\hline \multirow[t]{2}{*}{ PРP $3 C A$} & $4 \mathrm{q} 24$ & CTGAAAGGCTTGACCCCAACTGGCATGCTCCСC & TCTGGAGGGAAGCAAACCCTGCAAAGCGGTA & $102,172,430-102,172,519$ \\
\hline & & AGCGGAGTACTTT & AGCAGGCTGATGGG & \\
\hline \multirow[t]{2}{*}{ SHANK2 } & $11 \mathrm{q} 13$ & ССТССАTGCTGCCTGGATCTGGCGAGCTGGGG & AATTGGCTATGATGATGAACGTCCCCGGCGG & $70,185,492-70,185,565$ \\
\hline & & TGATT & AGGAGC & \\
\hline SLC5A7 & $2 \mathrm{q} 12.3$ & CAACACСТGTCAACTCTGCGCGCTCCCAGGT & TCTTGGAGACGCCGAGTGAGGAGCCGCCCTG & $107,969,453-107,969,514$ \\
\hline \multirow[t]{2}{*}{ STRC } & $15 q 15.3$ & САACTGGATCCTATTACAGCAATTTGACAACAA & ATTCAGGTGGAGCTGGGCCAAGTCGAGAAG & $41,684,948-41,684,880$ \\
\hline & & CAGG & GG & \\
\hline \multirow[t]{2}{*}{ TUBB2A } & $6 \mathrm{p} 25$ & CGCGATAGTCTTGCTGCCAGTCCCCGAGGCGG & CTGCGCTGGGTGGGGGCTGCAATTACCGACC & $3,102,089-3,102,166$ \\
\hline & & CAGGTGA & GCTGTGTG & \\
\hline
\end{tabular}


Tabela VII. Conjunto MLPA-B, com as sondas correspondentes aos genes, região cromossômica, sequências proximal e distal para hibridação e posição genômica de cada sonda (da extremidade 5' da sequência proximal até a extremidade 3’ da sequência distal).

\begin{tabular}{|c|c|c|c|c|}
\hline \multirow{2}{*}{ Gene } & \multirow{2}{*}{ Região } & \multicolumn{2}{|c|}{ Sequências para hibridação (5’ $\left.\rightarrow 3^{\prime}\right)$} & \multirow{2}{*}{ Posição genômica } \\
\hline & & Proximal & Distal & \\
\hline EMCN & $4 \mathrm{q} 24$ & GCTGTCTTCCTGTTCCCCCAGAGCGGCTCAG & GTGGCTGAGACACCTGTCCAATCTCAGAGCC & $101,626,860-101,626,921$ \\
\hline \multirow[t]{2}{*}{ FGF19 } & $11 \mathrm{q} 13$ & CCGAGAGCCCCAGGGAGGTGCCATGCGGAG & ACGTATGGATCCTGGCCGGCCTCTGGCTGGC & $69,227,754-69,227,847$ \\
\hline & & CGGGTGTGTGGTGGTCC & CGTGGCCGGGCGCCCC & \\
\hline FOXF2 & $6 \mathrm{p} 25$ & AGCGCCATCGAATGCCACTCGCCCT & ACACGAGCCCTGCGGCGCACTGGAG & $1,336,154-1,336,203$ \\
\hline MYLK4 & $6 \mathrm{p} 25$ & GСССССТСССТGАССТССССАAGGGCАСТСА & TGACCGTGACCGTGCCTCAGTAGCTCCGTCC & $2,630,513-2,630,452$ \\
\hline TMC1 & $9 \mathrm{q} 13$. & TGCTGGGCCGTTATGTGCTGC & AATGTTCCTGAGGCCAGGGTC & $74,625,651-74,625,692$ \\
\hline TMC2 & $20 \mathrm{p} 13$ & TTCCAGTGCTGGGCGGTGATGAG & CAGCAACGTACCCCATGAACGCG & $2,545,785-2,545,830$ \\
\hline TMC3 & $15 q 25.1$ & ATGCCCCAGAGCCCGAGGCCAGGGGAC & AGGGCTCСTAGCTCAССТСTCССTGGG & $79,414,151-79,414,204$ \\
\hline TMC4 & $19 \mathrm{q} 13$ & тCTGTGGCCTCTGTCCTGGGGCGCTGGGT & CGTCTGGCGGGGACCCAGGAGTTCCAGGT & $59,357,771-59,357,828$ \\
\hline \multirow[t]{2}{*}{ TMC5 } & $16 \mathrm{p} 12.3$ & GACCCGCTTCTCTGCCTACATGGTAGCCTGGG & TGTCTCTACAGGAGTGGCCATAGCCTGCTGT & $19,390,967-19,391,032$ \\
\hline & & $\mathrm{T}$ & GC & \\
\hline \multirow[t]{2}{*}{ TMC6 } & $17 \mathrm{q} 25.3$ & ССTGGCTGCCCTGGGTGCACCGGTACCTGAT & CTTTGTCTTCCTGGTGTCAGCCCTGCTGCTGT & $73,625,216-73,625,131$ \\
\hline & & GGAAAACACCT'T & GAGTCCCGCAG & \\
\hline TMC7 & $16 \mathrm{p} 12.3$ & AAGGCTCGAGAGATGACGACCCACC & TGGAGCTGTGGCGGGAGGACATCCG & $18,935,361-18,935,410$ \\
\hline \multirow[t]{2}{*}{ TMC8 } & $17 \mathrm{q} 25.3$ & TGGACCGGTTCTCAGGCCGGTTCTGGGCCTG & ACGGGAGGAGTTCCTGGTCCCCAAGAATGTG & $73,645,689-73,645,762$ \\
\hline & & GCTGGA & CTGGAC & \\
\hline \multirow[t]{2}{*}{ TPCN2 } & $11 \mathrm{q} 13$ & CGGGTGGGCCCATTTCCAGAAAAACCTTTGG & АCCTCGTGGTGCTGGTGGTGTCTCTGGTGGA & $68,581,633-68,581,714$ \\
\hline & & CTGCTGGGCT & CTGGACCGTG & \\
\hline
\end{tabular}


Tabela VIII. Novas sondas para IMMP2L, STRC e TMC6, com suas sequências proximal e distal para hibridação e posição genômica de cada sonda (da extremidade 5' da sequência proximal até a extremidade 3' da sequência distal).

\begin{tabular}{|c|c|c|c|}
\hline \multirow{2}{*}{ Gene } & \multicolumn{2}{|c|}{ Sequências para hibridação $\left(5^{\prime} \rightarrow 3^{\prime}\right)$} & \multirow{2}{*}{ Posição genômica } \\
\hline & Proximal & Distal & \\
\hline \multirow[t]{2}{*}{$I M M P 2 L$} & GAGTCCTGCGTGATCGCGAGCATGTGTGCG & GTTTATCTGAGGCGCGTGCGGCGGCCACCCCA & $110,989,503-110,989,576$ \\
\hline & TGCGCGT & GCCTA & \\
\hline \multirow[t]{2}{*}{ STRC } & САACTGGATCCTATTACAGCAATTTGACAAC & ATTCAGGTGGAGCTGGGCCAAGTCGAGAAGG & $41,684,880-41,684,948$ \\
\hline & AACAGG & G & \\
\hline TMC6 - éxon 16 & GCCGCTGTCTTCCTCTGCTACGCCGTCTGGC & AGTGAGTGGGGCGGGTGGAGGGAGACCCTTC & $73,625,448-73,625,509$ \\
\hline TMC6 - éxon 18 & TGTGGCCCTGGGCCCTGCCCGACA & GCCCСTCTCCCGCAGGGCCGTGATCT & $73,625,013-73,625,062$ \\
\hline
\end{tabular}


enzima ligase adição da enzima ligase. Os ciclos da etapa de ligação foram os seguintes: 15 mina $54{ }^{\circ} \mathrm{C}$ seguidos de 5 min a $98{ }^{\circ} \mathrm{C}$ para inativação térmica da enzima. Finalmente, a última etapa consistiu de amplificação por PCR, com as seguintes condições de amplificação: 35 ciclos de 30 s a $95^{\circ} \mathrm{C}, 30$ s a $60^{\circ} \mathrm{C}$ e 60 s a $72{ }^{\circ} \mathrm{C}$, e por fim 20 min de incubação a $72{ }^{\circ} \mathrm{C}$.

Após a amplificação por PCR, os produtos obtidos foram separados juntamente com um padrão de peso molecular por eletroforese em capilar pelo aparelho MegaBACE 1000 (Amersham Biosciences, Buckinghamshire, UK) e em parte dos experimentos pelo ABI 3730xl DNA Analyzer (Applied Biosystems, Foster City, California, USA). Para as corridas realizadas no MegaBACETM 1000, a análise das sondas fluorescentes foi realizada pelo programa Fragment Profiler 1.2, que acompanha o aparelho, e dados como altura dos picos foram exportados para uma planilha do Microsoft Excel. Já no caso das corridas realizadas pelo a ABI 3730xl DNA Analyzer, foi utilizado o software GeneMarker (SoftGenetics, State College, Pennsylvania, USA), que lê os picos de fluorescência e já fornece os resultados analisados.

$\mathrm{Na}$ análise dos resultados, as alturas dos picos de fluorescência de cada sonda referente a cada indivíduo foram normalizadas de modo a indicar um valor que permita estimar o número de cópias do gene desse indivíduo. Existem vários métodos para a normalização dos dados de MLPA. Utilizamos para a análise da maioria de nossos dados a seguinte fórmula:

1. Normalização intra-amostra: a altura do pico referente ao produto da amplificação de uma sonda de um indivíduo foi dividida pela média das alturas dos picos de todas as sondas do mesmo indivíduo testado;

2. Normalização final: o valor obtido na normalização intra-amostra foi dividido pela média das alturas dos picos referentes à mesma sonda de todas as amostras controle. Esse valor obtido é o utilizado para estimar o número de cópias.

Valores abaixo de 0,7 foram considerados como indicativos de deleção e valores acima de 1,3 como indicativos de duplicação do gene. Espera-se que indivíduos com número normal de cópias para um determinado gene tenham o valor correspondente da sonda próximo de 1,0 . 
Uma vez que é o conjunto da altura dos picos que fornecerá informações acerca do número de cópias, torna-se necessário observar alguns cuidados para a obtenção de resultados confiáveis. Inicialmente, a comparação dos dados (isto é, das alturas dos picos de fluorescência) só deve ser feita sempre entre as amostras da mesma corrida, ou seja, amostras que foram submetidas à mesma reação de MLPA, o que significa que uma única amostra de DNA de baixa qualidade pode comprometer a precisão dos resultados. A intensidade da fluorescência de cada sonda também deve se aproximar das condições ideais. Além disso, cada corrida de MLPA requer a análise de pelo menos três amostras de indivíduos normais como controle para a normalização final.

Todas as análises que indicaram alterações foram repetidas ao menos uma vez para confirmação.

\section{III.2.5. Sequenciamento de DNA}

Os genes indicados pelo MLPA como alterados na casuística foram sequenciados com o objetivo de detectar pontos de quebra ou possíveis outras mutações menores que poderiam estar contribuindo ao fenótipo de surdez e seus quadros clínicos associados. Sequenciamos todos os éxons dos genes TMC6 e IMMP2L com exceção do éxon 1, não codificador de aminoácidos em ambos os genes. Os primers para sequenciamento dos dois genes foram desenhados utilizando-se o software Primer3 (Rozen e Skaletsky, 2000). As sequências dos primers estão disponíveis na Tabela IX.

A PCR para amplificação dos fragmentos para sequenciamento foi do tipo Touchdown-PCR, a qual consiste de um ciclo de 5 min de desnaturação inicial a $94{ }^{\circ} \mathrm{C}$, com 14 ciclos de desnaturação a $94{ }^{\circ} \mathrm{C}$ por $30 \mathrm{~s}$, hibridação a $69^{\circ} \mathrm{C}$ por $40 \mathrm{~s}$ com a redução dessa temperatura em $0,5^{\circ} \mathrm{C}$ em cada ciclo e extensão por 1 min a $72{ }^{\circ} \mathrm{C}$. Em seguida são realizados 23 ciclos de desnaturação a $94{ }^{\circ} \mathrm{C}$ por $30 \mathrm{~s}$, hibridação a $62{ }^{\circ} \mathrm{C}$ por $40 \mathrm{~s}$, extensão a $72^{\circ} \mathrm{C}$ por 1 min e, por fim, uma extensão final de 10 min a $72{ }^{\circ} \mathrm{C}$.

Os produtos da amplificação foram purificados pelo Illustra GFX PCR DNA and gel purification Kit (GE Healthcare, Little Chalfont, Buckinghamshire, UK), segundo instruções do fabricante. Os produtos purificados foram então submetidos à reação de sequenciamento, na qual a cada produto foi adicionada uma solução de reação contendo um dos respectivos primers e o BigDye Terminator v3.1 Cycle Sequencing (Applied Biosystems). Por fim, o sequenciamento automático foi realizado pelo aparelho $A B I$ 3730xl DNA Analyzer (Applied Biosystems). 
Tabela IX. Sequências dos primers para sequenciamento dos genes TMC6 e IMMP2L.

\begin{tabular}{|c|c|c|c|}
\hline Gene & Éxon & Primer forward $\left(5^{\prime} \rightarrow 3^{\prime}\right)$ & Primer reverse $\left(5^{\prime} \rightarrow 3^{\prime}\right)$ \\
\hline \multirow[t]{18}{*}{ TMC6 } & 2 & CCAGGCTCTGAGCTACCCTA & САССТСТСТССТТССАGСАG \\
\hline & 3 & AGAGAGGTGGCTGGAGCCT & GTCCACACCACCCAGCAT \\
\hline & 4 & AGGACCCCTGGTGAGTCTTT & CAGCCACTACCCAGGGAGAT \\
\hline & 5 & AAGGATTTTCCTGGGTCCTG & CTCCAGTGCCCACTCACTC \\
\hline & 6 & TTGGCGACTGAAGCTCAAAT & CTAGCCCAGCTGAGGAAGTG \\
\hline & 7 & GAGAGAGTCAGGCCССТCAT & CAGAGAGGCCCTGAGGGT \\
\hline & 8 & ACССTCAGGGCCTCTCTG & CGGTACCAGGGTAGCAGAAG \\
\hline & 9 & AAAGTCCCTGACTCGGCTG & ATGGGTCGAAAGATGAATGG \\
\hline & 10 & TTGTTGGTTGCCATGTCTGT & GGTTCTGGTCACATGGTCCT \\
\hline & 11 & GTGCTCTGGTGTGGGTGAC & AGAGTCACTGGGGACACGTTT \\
\hline & 12 & СTTCCATGACACCGCTCC & AATGATGTTTTCATGTGCGG \\
\hline & 13 & TCCGGGTGTATCCAAACCTA & GAACACTCACCACCCAGTCC \\
\hline & 14 & CATGGCTTTCCCATCTAACG & GCCAGACAGTAGGAGGCAAG \\
\hline & 15 & GTCTGGAACCAGCCTGATCT & GGTGGGGAGGGTTCTAGTGT \\
\hline & 16 & GTAGCAGGATGGTGGCAGAG & ACCCCCAGATGACACAGAAG \\
\hline & 17 & GTTCCTGGTCGGCATCTTC & TGTTGAGGTAGATCACGGCC \\
\hline & 18 & CCGGTACCTGATGGAAAACA & GGAGATGTACAGGGGAGTGG \\
\hline & 19 & GCTGCTTGCGATGTTGAATA & GGTCAAAAGCGGTCAAGTGT \\
\hline \multirow[t]{6}{*}{$I M M P 2 L$} & 2 & GACAAGATTGCCCTTCGGTA & CCTTTCAGTTCCCAGAATAGGA \\
\hline & 3 & GTGCAAGAACCATGAAGATTGA & AGTGGATTACCAGTTAAATCAGCA \\
\hline & 4 & GGGGTGCAAAGGAATCTGTA & GCCCTCATGGACTTCAGATG \\
\hline & 5 & ATGCCCAGCAGTTTGATCTC & TCAGTCTTGGCTGAGTTACCTG \\
\hline & 2 & GACAAGATTGCCCTTCGGTA & CCTTTCAGTTCCCAGAATAGGA \\
\hline & 6 & CCTGGGATGTTAAACCTGGA & AATGCCAGCAACTCAGGTAGAT \\
\hline
\end{tabular}

III.2.6. Triagem de uma variante não descrita por PCR-RFLP (Restriction Fragment Length Polymorphism)

Uma variante não descrita (c.1280C $>$ T) foi detectada em heterozigose no sequenciamento do éxon 10 do gene TMC6 em um dos pacientes. Triamos a variante em 100 de nossos indivíduos controle por PCR-RFLP utilizando a enzima BccI (New England Biolabs, Hitchin, Hertfordshire, UK). O resultado da digestão foi visualizado por meio de gel de poliacrilamida a $6 \%$. 
IV. Resultados E Discussão 


\section{RESUlTADOS E DisCUSSÃO}

\section{IV.1. Padronização das sondas in-house de MLPA}

A primeira etapa dos experimentos consistiu na padronização da hibridação dos dois conjuntos de sondas in-house de MLPA. Utilizamos primeiramente amostras de cinco indivíduos fenotipicamente normais para observar a qualidade do resultado obtido com as sondas desenhadas antes de aplicá-las na casuística.

As primeiras corridas revelaram a boa qualidade da grande maioria das sondas e praticamente não foram feitos ajustes para um melhor desempenho na reação de MLPA. Somente duas sondas mostraram má qualidade nos resultados: as dos genes PPP3CA e EMCN, curiosamente pertencentes à mesma região cromossômica (4q24), apresentaram picos muito baixos de fluorescência em todas as amostras. Isso poderia comprometer a análise de todas as sondas, o que nos obrigou a desenhar novas sondas para os dois genes.

A nova sonda para PPP $3 C A$ mostrou-se adequada para os experimentos. Por sua vez, a nova sonda para EMCN apresentou mais uma vez picos muito baixos. $\mathrm{Na}$ realidade, já havíamos tido dificuldade ao desenhar sua primeira sonda, pois seus éxons possuem sequências que não se adequavam aos critérios de construção de sondas inhouse. Após várias tentativas, conseguimos desenhar as duas sondas a partir do íntron 1. Porém, ambas apresentaram resultados de qualidade ruim. Íntrons podem trazer problemas ao MLPA porque podem incluir SNPs não conhecidos ou regiões repetitivas. Assim, é ideal que as sondas sejam construídas a partir de sequências exônicas.

Em geral, a qualidade das sondas in-house depende basicamente de seu desenho e comprimento total, isto é, a hibridação das sondas de comprimentos maiores é menos eficiente em comparação às de menores comprimentos. No caso do gene EMCN, à exceção do fato de termos construído sondas a partir de íntrons, seguimos basicamente os parâmetros para desenho e as duas sondas possuíam comprimento intermediário. Não sabemos explicar exatamente as razões de termos obtido sondas de qualidade insatisfatória para esse gene, fato que poderia ser atribuído às sequências intrônicas ou não. Em vista das dificuldades técnicas, optamos por descartar definitivamente o gene EMCN de nossa seleção. Assim, ficamos com um total de 25 genes candidatos. 


\section{IV.2. Comparação entre os resultados do array-CGH e os resultados do MLPA}

Após a padronização das sondas com indivíduos fenotipicamente normais, decidimos estudar o material dos sete pacientes (Pacientes 2 a 8 - Tabela IV, p. 33) com rearranjos detectados por array-CGH. Essa etapa foi importante para atestar a eficiência das sondas nos casos em que o gene candidato estava certamente incluído no rearranjo e também para refinar os limites do rearranjo naqueles casos em que o gene selecionado localizava-se em região não coberta pelas sondas do array-CGH. Os resultados de MLPA em amostras dos sete pacientes encontram-se na Tabela X.

Tabela X. Resultados obtidos por MLPA em amostras dos sete pacientes portadores de surdez sindrômica previamente estudados por array-CGH.

\begin{tabular}{|c|c|c|c|}
\hline Paciente & $\begin{array}{l}\text { Rearranjo detectado } \\
\text { por array-CGH }\end{array}$ & Genes candidatos & Resultado MLPA \\
\hline 2 & Duplicação & KIF5C & 1,38 \\
\hline \multirow[t]{5}{*}{3} & Duplicação & FOXQ1 & 0,93 \\
\hline & & FOXF2 & 1,44 \\
\hline & & FOXC1 & 1,49 \\
\hline & & MYLK4 & 1,52 \\
\hline & & TUBB2A & 0,90 \\
\hline \multirow[t]{5}{*}{4} & Deleção & TPCN2 & 0,54 \\
\hline & & FGF19 & 0,49 \\
\hline & & FGF3 & 0,44 \\
\hline & & CTTN & 0,40 \\
\hline & & SHANK2 & 0,58 \\
\hline 5 & Duplicação & SLC5A7 & 1,41 \\
\hline 6 & Deleção & PРP3CA & 0,97 \\
\hline \multirow[t]{2}{*}{7} & Deleção & $I M M P 2 L$ & 1,00 \\
\hline & & LRRN3 & 0,99 \\
\hline \multirow[t]{2}{*}{8} & Deleção & $M A P 1 A$ & 1,07 \\
\hline & & STRC & 1,11 \\
\hline
\end{tabular}


No caso do Paciente 2, o resultado de MLPA (duplicação de KIF5C) foi compatível com o resultado do array-CGH.

O Paciente 3, portador de duplicação, teve três (FOXF2, FOXC1 e MYLK4) dos cinco genes candidatos estudados com valores de MLPA indicando duplicação. A sonda do gene FOXQ1 revelou que a região correspondente à sonda desenhada (1,258,769-1,258,826) não está duplicada. Logo, a duplicação não abrange este segmento e, portanto, foi possível mapear nesse paciente seu ponto de quebra distal, que deve estar entre FOXQ1 e o gene proximal a ele adjacente, FOXF2 (que dista 77 kb) ou ainda no próprio gene FOXQ1, fora da região que hibrida com a sonda. Quanto a TUBB2A, esperava-se resultado normal de MLPA e que foi confirmado, de acordo com os dados do refinamento posterior feito por 105.000 oligoarrays (105k) da Agilent Technologies (Fig. 4).

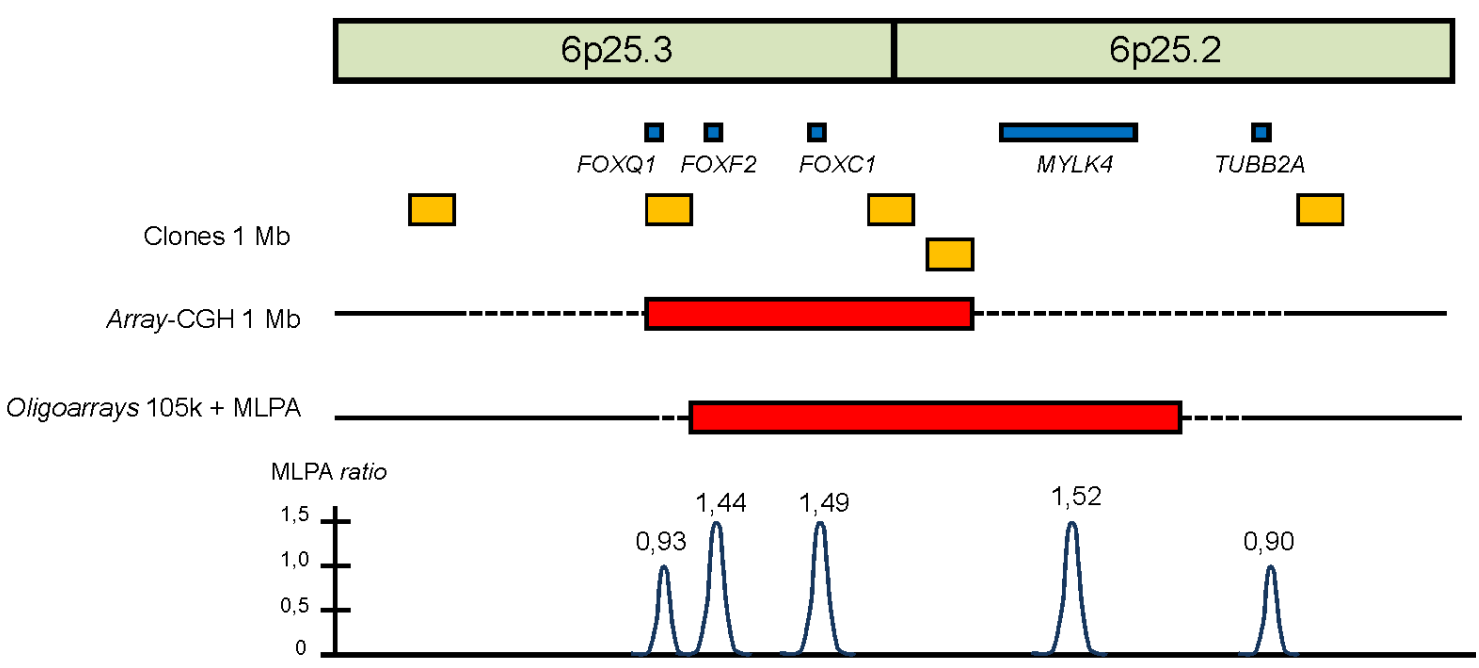

Fig. 4. Duplicação no Paciente 3 em 6p25.3p25.2. A barra verde representa a região cromossômica, as barras azuis representam os genes e as barras amarelas representam os clones de $1 \mathrm{Mb}$. A barra vermelha superior representa a duplicação como mapeada pelo array-CGH de $1 \mathrm{Mb}$ e a barra vermelha inferior, pelos oligoarrays de 105k e MLPA. As linhas tracejadas representam as regiões não cobertas pelas sondas de array-CGH e que poderiam também estar comprometidas pelo rearranjo. No gráfico inferior estão os resultados de MLPA correspondentes às sondas de cada gene.

O Paciente 4 teve todos os resultados do MLPA concordantes com os do arrayCGH (deleção de TPCN2, FGF19, FGF3, CTTN e SHANK2), conforme esperado.

No Paciente 5, o gene escolhido a partir de seu resultado de array-CGH, SLC5A7, poderia ou não estar duplicado por se localizar fora da região coberta pelos 
clones de $1 \mathrm{Mb}$. O resultado de MLPA desse paciente revelou que esse gene está incluído na região duplicada, aumentando o tamanho mínimo da duplicação estimado em 0,21 Mb para 0,38 Mb (Fig. 5).

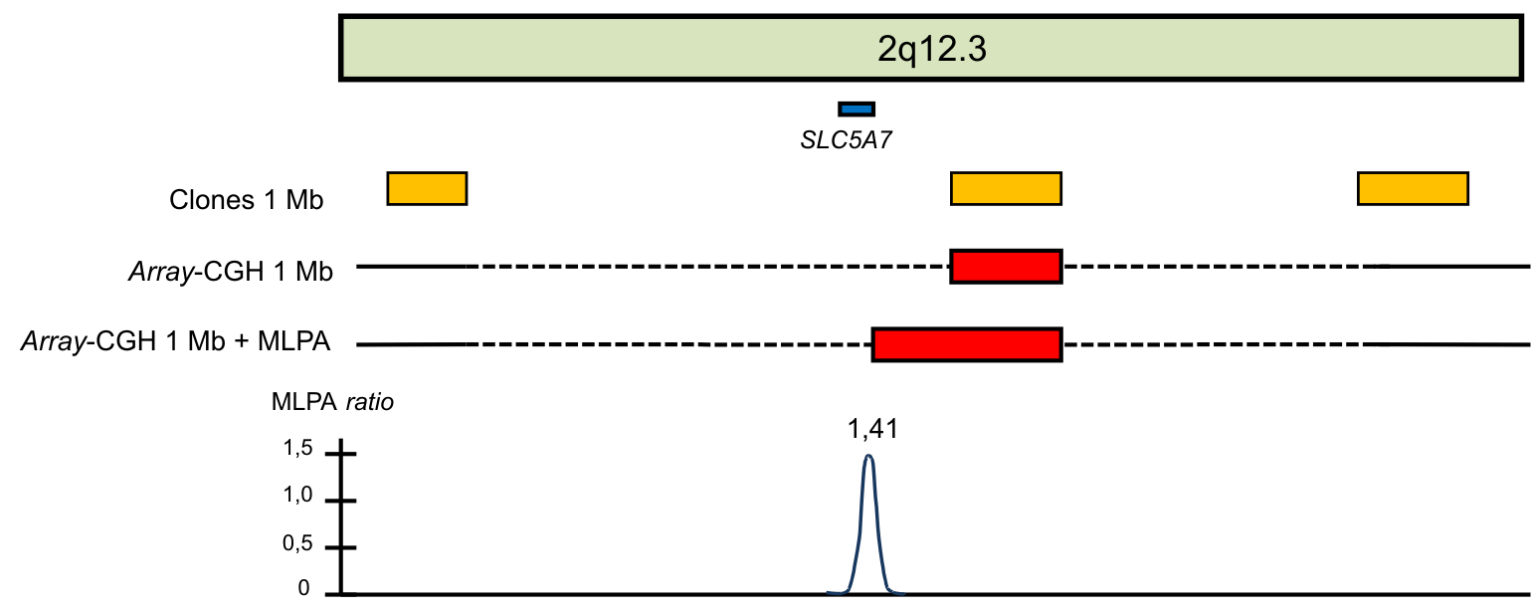

Fig. 5. Duplicação no Paciente 5 em 2q12.3. A barra verde representa a região cromossômica, a barra azul representa o gene $S L C 5 A 7$, as barras amarelas representam os clones de $1 \mathrm{Mb}$, a barra vermelha superior representa a duplicação como mapeada pelo array-CGH de $1 \mathrm{Mb}$ e a barra vermelha inferior, a duplicação como mapeada com a informação adicional do MLPA. As linhas tracejadas representam as regiões não cobertas pelos clones de $1 \mathrm{Mb}$ e que poderiam estar incluídas no rearranjo. No gráfico inferior está o resultado de MLPA correspondente à sonda para o gene SLC5A7.

No caso do Paciente 6, o resultado do MLPA para o gene $\operatorname{PPP} 3 C A(0,97)$ não revelou deleção. Este gene encontra-se em região não coberta pelas sondas da plataforma utilizada e, por essa razão, poderia ou não estar deletado (Fig. 6). Concluímos com os dados do MLPA que a deleção presente no Paciente 6 realmente não abrange este gene ou pelo menos não inclui a região que vai do éxon 1 ao 12, a partir do qual a sonda foi desenhada. Esse resultado permitiu reduzir o tamanho máximo estimado da deleção de 2,07 para 1,02 Mb. A deleção inclui com certeza o gene EMCN, porém, como mencionado anteriormente, esse gene foi descartado de nossa análise por problemas técnicos. 


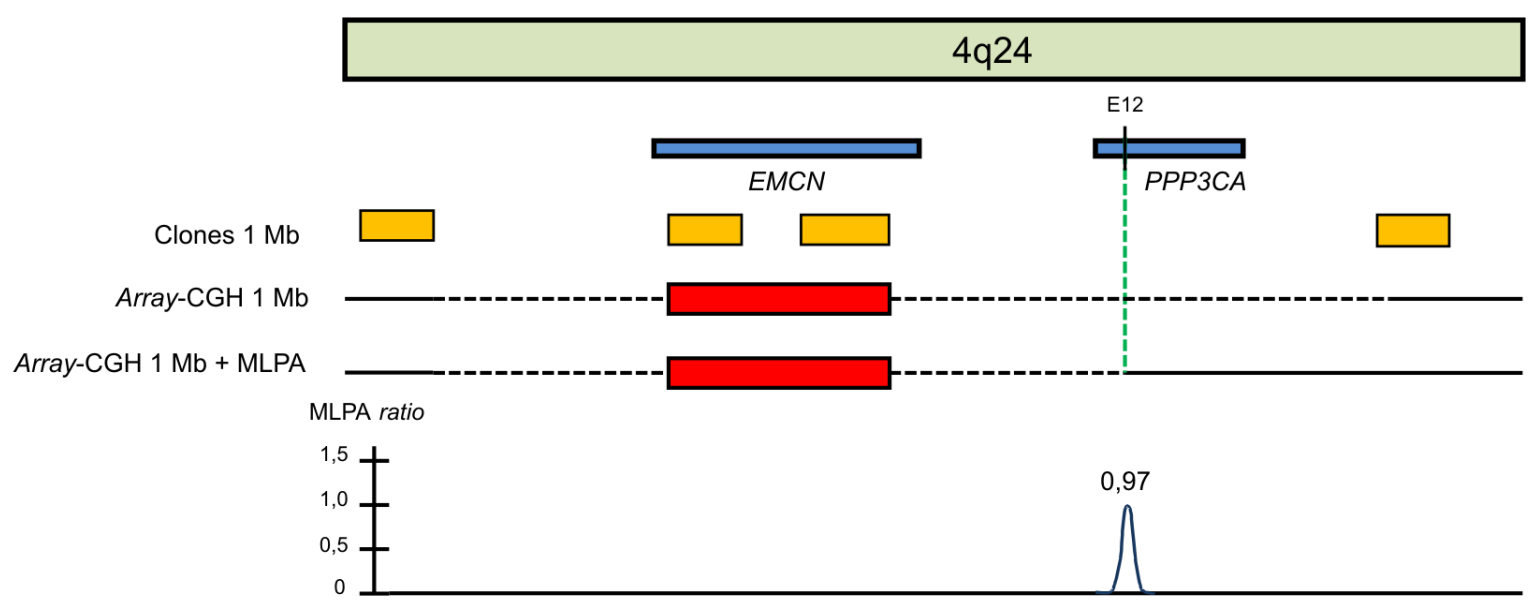

Fig. 6. Deleção no Paciente 6 em 4q24. A barra verde representa a região cromossômica, as barras azuis representam os genes, as barras amarelas representam os clones de $1 \mathrm{Mb}$, a barra vermelha superior representa a deleção como mapeada pelo array-CGH de $1 \mathrm{Mb}$ e a barra vermelha inferior, a deleção como mapeada com a informação adicional do MLPA. As linhas tracejadas representam as regiões não cobertas pelos clones e que poderiam também estar inclúdas no rearranjo. A linha verde tracejada vertical indica a região correspondente ao éxon 12 de $P P P 3 C A$. No gráfico inferior está o resultado de MLPA correspondente à sonda para PPP $3 C A$.

De acordo com o resultado do array-CGH de $1 \mathrm{Mb}$, o Paciente 7 apresentava uma deleção que abrangia, no mínimo, certamente a porção terminal do gene IMMP2L e, possivelmente, o gene LRRN3. Os resultados do MLPA indicam que as sondas para esses genes não estão deletadas (valores 1,00 e 0,99, respectivamente). $\mathrm{Na}$ realidade, a sonda para IMMP2L foi desenhada a partir do éxon 2, que certamente não é abrangido pela deleção; logo, seu resultado de MLPA era esperado. Embora soubéssemos que a região do éxon 2 não estava incluída no rearranjo, foi impossível desenhar sondas em seus éxons mais terminais. Ainda na tese de Catelani (2010), este paciente também teve material estudado por uma plataforma de array-CGH de maior resolução, 44.000 oligoarrays da Agilent Technologies (44k), que delimitou a deleção a uma região que inclui, no máximo, os éxons de 4 a 6 de IMMP2L (Fig. 7). Isto nos revela que, de fato, LRRN3 não estava incluído na deleção. Assim, o resultado de LRRN3 é coerente, tendo em vista as informações do array-CGH de 44k. 


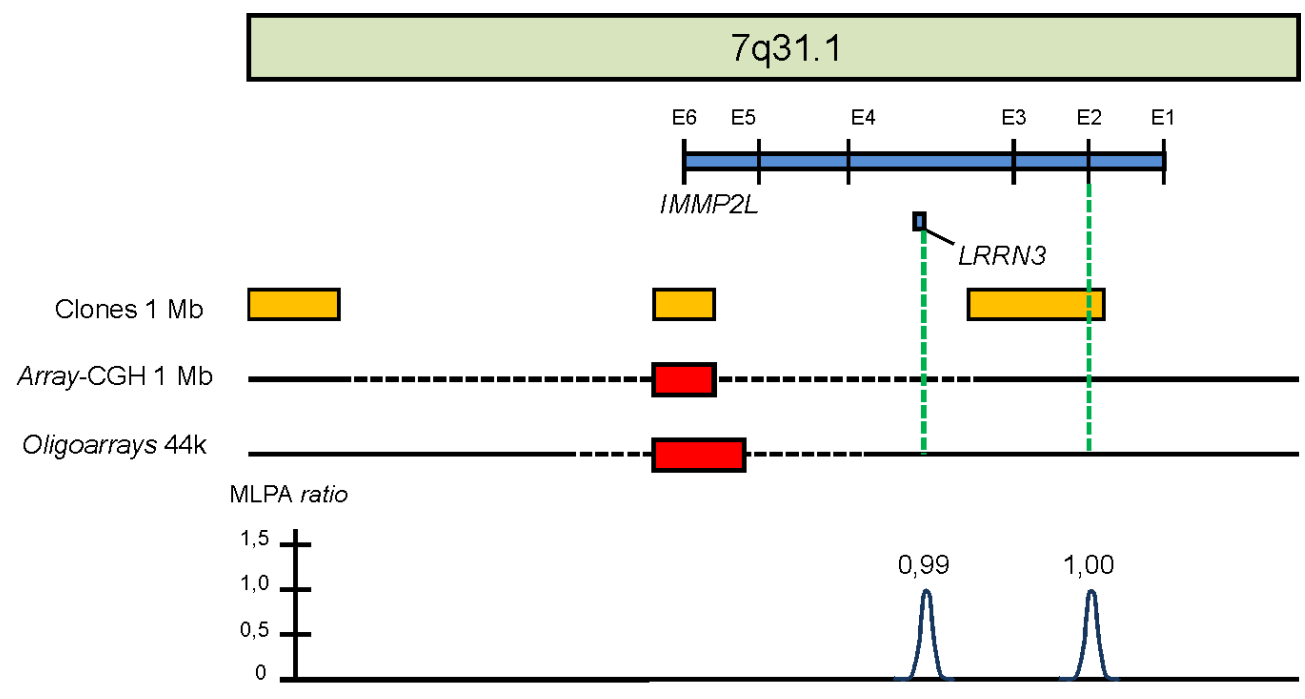

Fig. 7. Deleção em 7q31.1 no Paciente 7. A barra verde representa a região cromossômica, as barras azuis representam os genes e as barras amarelas representam os clones de $1 \mathrm{Mb}$. A barra vermelha superior representa a duplicação como mapeada pelo array-CGH de $1 \mathrm{Mb}$ e a barra vermelha inferior, pelos oligoarrays de 44k. As regiões não cobertas pelas sondas possivelmente comprometidas pelo rearranjo estão representadas pelas linhas pretas tracejadas. As linhas verdes tracejadas na vertical indicam as regiões correspondentes à sonda para LRRN3 e à sonda para $I M M P 2 L$, em seu $2^{\circ}$ éxon. No gráfico inferior estão os resultados de MLPA correspondentes às sondas de cada gene. E: éxon.

O Paciente 8 apresentou um resultado de MLPA que à primeira vista não concordava com o esperado pelo array-CGH: a sonda para o gene STRC apresentou um valor $(1,11)$ indicativo de número normal de cópias. Já a sonda para $M A P 1 A$ também indicou número normal de cópias, o que significa que a deleção não inclui esse gene, que se localiza em região não coberta pelas sondas de $1 \mathrm{Mb}$ (Fig. 8).

$\mathrm{Na}$ realidade, trata-se de um caso complexo, pois o gene STRC localiza-se numa região naturalmente duplicada em tandem que compreende mais três genes, HISPPD2A, CKMT1B e CATSPER2. Assim, STRC possui duas cópias. A cópia proximal corresponde ao gene ativo e a distal, a um pseudogene (Fig. 9). As duas cópias distam menos de $100 \mathrm{~kb}$ uma da outra. 


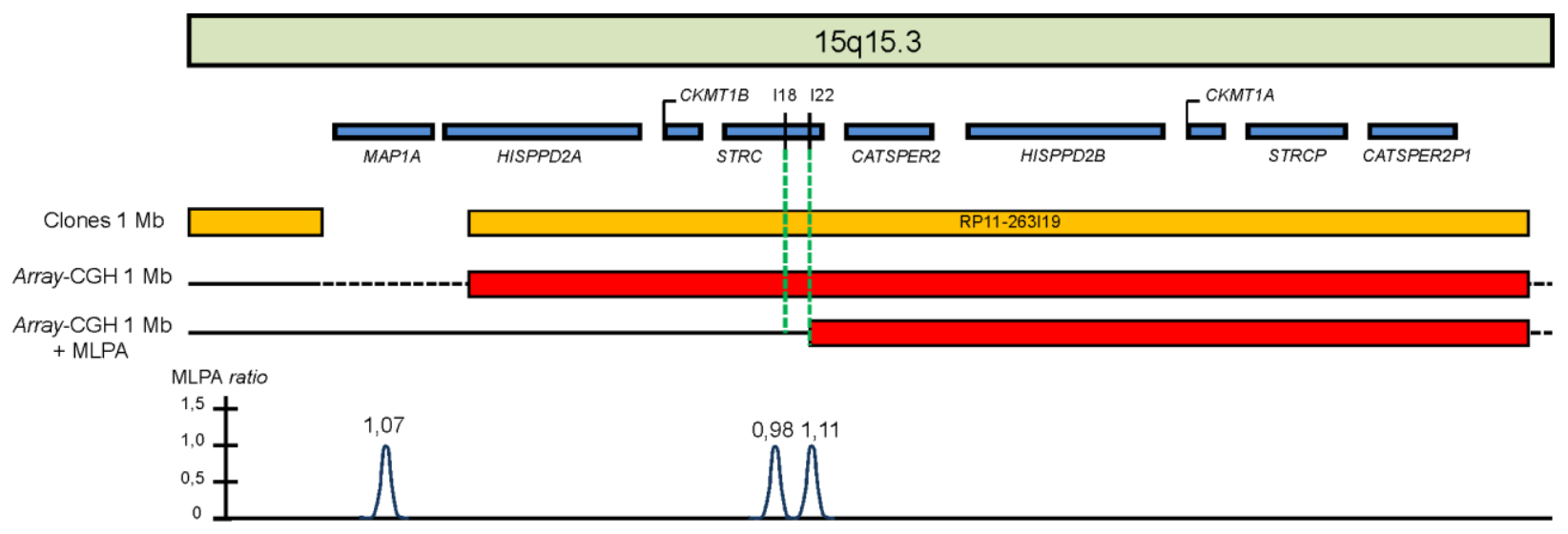

Fig. 8. Deleção no Paciente 8 em 15q15.3. A barra verde representa a região cromossômica, as barras azuis representam os genes e pseudogenes dessa região, as barras amarelas representam os clones de $1 \mathrm{Mb}$, incluindo RP11-263I19, a barra vermelha superior representa a deleção como mapeada pelo array-CGH de $1 \mathrm{Mb}$, e a inferior, com a informação adicional do MLPA. As regiões não cobertas pelas sondas e possivelmente comprometidas pelo rearranjo estão representadas pelas linhas pretas tracejadas. As linhas verdes tracejadas na vertical indicam as regiões correspondentes às duas sondas para STRC, desenhadas em seus íntrons 18 e 22. No gráfico inferior estão os resultados de MLPA correspondentes à sonda para MAP1A e às sondas para STRC a partir dos íntrons 18 e 22. I: íntron.

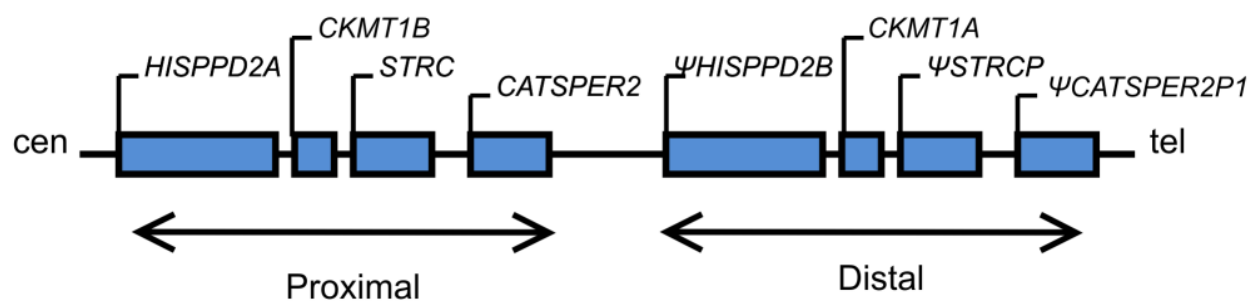

Fig. 9. Representação da região duplicada em tandem em 15q15.3 englobando os genes HISPPD2A, CKMT1B, STRC e CATSPER2. Os genes e peseudogenes estão representados pelas barras azuis; os pseudogenes estão identificados pelo símbolo $\Psi$. Cen: centrômero; tel: telômero (modificado de Avidan e col., 2003).

O experimento de array-CGH realizado no paciente havia indicado deleção da região correspondente a uma única sonda, RP11-263I19, a qual hibrida com as duas cópias de STRC. Para sanar possíveis dúvidas acerca da especificidade da sonda de MLPA para a cópia ativa de STRC, a qual fora desenhada a partir do íntron 22, e aproveitando a disponibilidade de outras sequências para MLPA desenhadas pelo grupo da Leiden University Medical Center, sintetizamos uma nova sonda, que hibrida no íntron 18. Após experimento com a nova sonda, observamos novamente número normal de cópias para o gene $\operatorname{STRC}(0,98)$. Essa aparente inconsistência em relação aos 
resultados do array-CGH pode ocorrer pelo fato deste método não ser capaz de discernir qual das cópias do gene STRC estaria deletada (gene ou pseudogene). Em contraste, a técnica de MLPA é mais refinada e ambas as sondas com certeza hibridam com sequências da cópia ativa. Portanto, nossos resultados de MLPA sugerem que, neste paciente, provavelmente é o pseudogene de STRC que está deletado e não sua cópia ativa.

Em síntese, nessa primeira etapa, os resultados do array-CGH foram reproduzidos por 12 das 17 sondas de MLPA e também foi possível redefinir a extensão dos rearranjos em quatro casos. No caso do Paciente 8, foi possível inferir que provavelmente a deleção desse paciente não ocorreu no gene STRC, e sim no seu pseudogene. Portanto, a técnica de MLPA, em razão de sua alta especificidade, mostrou-se uma ferramenta muito eficiente para validar resultados de array-CGH ou refinar os rearranjos por ele detectados.

\section{IV.3. Triagem de alterações na casuística selecionada por MLPA}

Procedemos à triagem de alterações no números de cópias com os conjuntos de sondas in-house na casuística selecionada de 163 pacientes com surdez estudados no laboratório. Os pacientes foram numerados de 1 a 163, dos quais os 31 primeiros são aqueles que foram previamente estudados por Catelani (2010) por array-CGH. Observamos uma duplicação no gene IMMP2L, seis deleções e uma duplicação no gene STRC e seis deleções no gene TMC6 (Tabelas XI e XII).

Os três genes foram investigados igualmente por MLPA em 189 indivíduos ouvintes, para observarmos a ocorrência dessas CNVs na população normal. Alterações nos três genes foram observadas na amostra controle em frequências similares às observadas nos pacientes (Tabela XII), com exceção do gene IMMP2L, em que o paciente apresentou duplicação, e os controles, deleção. Nos portadores de alterações dos genes IMMP2L e TMC6 da amostra controle, os éxons a partir dos quais as sondas para esses genes foram desenhadas (2 e 17, respectivamente) foram sequenciados para verificar presença de possível SNP não catalogado ou outra variante que pudesse estar na região de ligação da sonda e assim interferir na hibridação. O resultado do sequenciamento foi normal para todos os indivíduos. Ou seja, não foram detectadas diferenças em relação às sequências de referência que interferissem na hibridação. 
Tabela XI. Alterações detectadas por MLPA em amostras de 163 pacientes com surdez sindrômica ou não-sindrômica.

\begin{tabular}{lllll}
\hline Paciente & Categoria & Alteração detectada & Gene & Valor \\
\hline Paciente 20 & Sindrômico & Deleção & STRC & 0,58 \\
Paciente 25 & Sindrômico & Deleção & TMC6 & 0,58 \\
& & Deleção & STRC & 0,53 \\
Paciente 27 & Sindrômico & Deleção & TMC6 & 0,50 \\
Paciente 29 & Sindrômico & Deleção & TMC6 & 0,52 \\
Paciente 41 & Sindrômico & Deleção & STRC & 0,54 \\
Paciente 78 & Não-sindrômico & Duplicação & IMMP2L & 1,51 \\
Paciente 97 & Não-sindrômico & Deleção & STRC & 0,54 \\
Paciente 117 & Não-sindrômico & Deleção & TMC6 & 0,62 \\
Paciente 119 & Não-sindrômico & Deleção & $S T R C$ & 0,52 \\
Paciente 128 & Não-sindrômico & Deleção & STRC & 0,51 \\
Paciente 134 & Não-sindrômico & Deleção & TMC6 & 0,56 \\
Paciente 146 & Não-sindrômico & Duplicação & $S T R C$ & 1,42 \\
Paciente 159 & Não-sindrômico & Deleção & TMC6 & 0,57 \\
\hline
\end{tabular}

Tabela XII. Frequências de alterações nos genes IMMP2L, TMC6 e STRC detectadas em pacientes com surdez e em indivíduos controle.

\begin{tabular}{lllll}
\hline Amostra & Gene & Alteração detectada & Frequência & Total \\
\hline Pacientes & IMMP2L & Duplicação & $1 / 163$ & $1 / 163(0,6 \%)$ \\
& STRC & Deleção & $6 / 163$ & \\
& & Duplicação & $1 / 163$ & $7 / 163(4,3 \%)$ \\
& TMC6 & Deleção & $6 / 163$ & $6 / 163(3,7 \%)$ \\
Controles & IMMP2L & Deleção & $3 / 189$ & $3 / 189(1,6 \%)$ \\
& STRC & Deleção & $8 / 189$ & $11 / 189(5,8 \%)$ \\
& & Duplicação & $3 / 189$ & $4 / 189(2,1 \%)$ \\
\hline
\end{tabular}

\section{IV.4. Investigação das alterações detectadas por MLPA}

\section{IV.4.1. Investigação das alterações no gene TMC6}

A suspeita inicial da relação do gene TMC6 com surdez parecia promissora: duas deleções em heterozigose foram detectadas em dois pacientes (25 e 29), e seriam 
supostamente de novo, pois os experimentos de MLPA com o material genético dos pais normais de ambos os pacientes revelaram número normal de cópias (Fig. 10). Tal fato reforçava a possibilidade de TMC6 ser a causa da surdez apresentada por esses dois pacientes, os quais são sindrômicos e já haviam sido previamente estudados por array$\mathrm{CGH}$, com resultados normais.

\section{A}

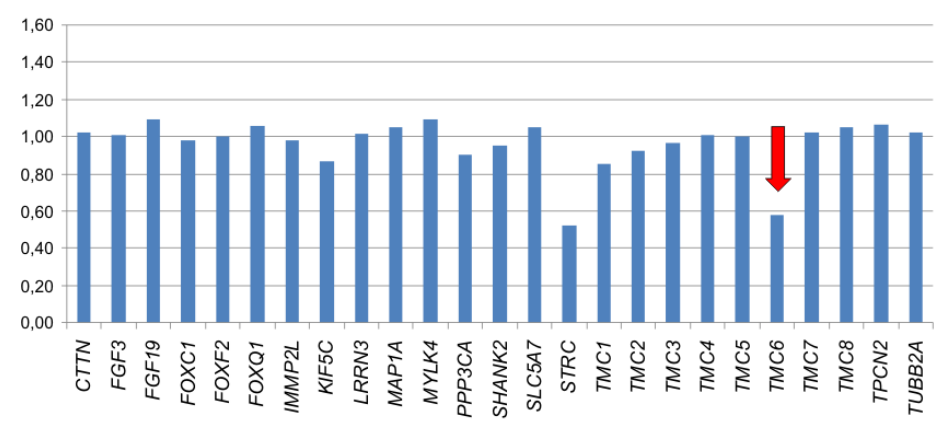

Paciente 25

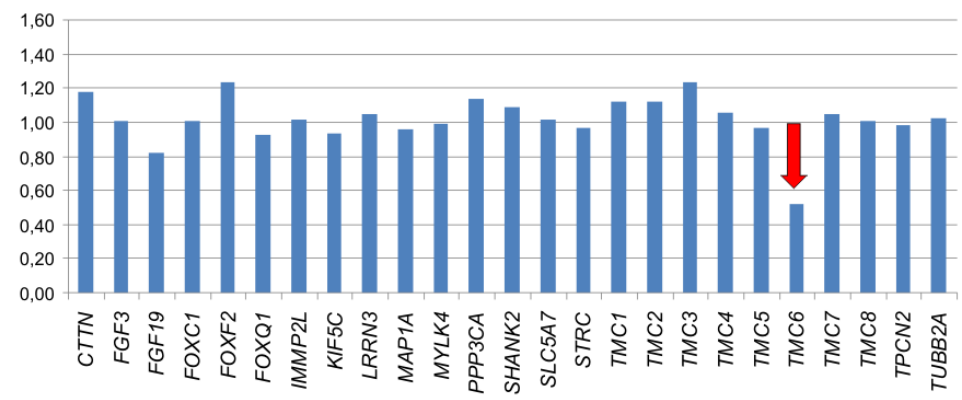

Paciente 29
B
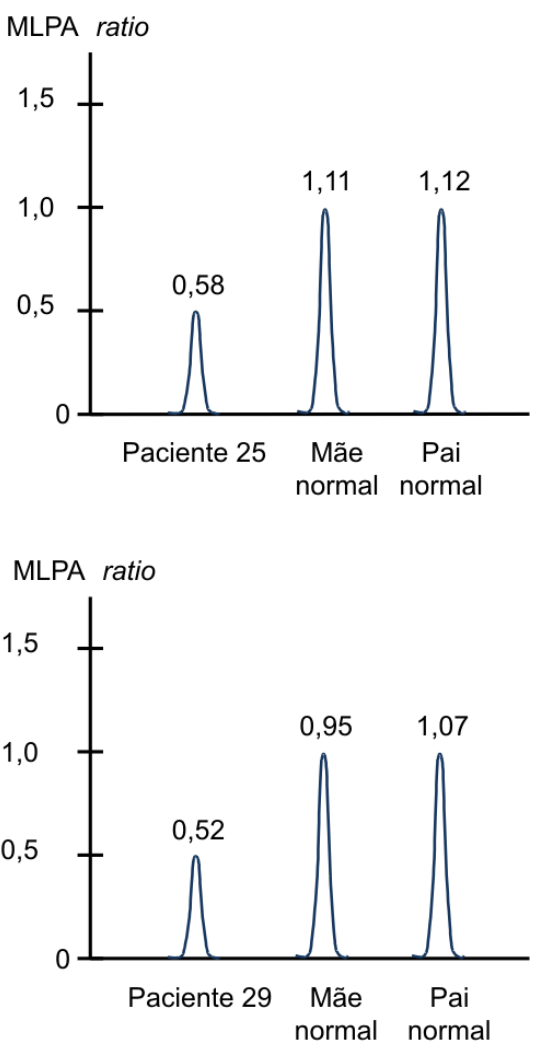

Fig. 10. Suposta deleção no gene TMC6 nos Pacientes 25 e 29. (A) Perfil das 25 sondas de MLPA em cada paciente, com destaque para as deleções em heterozigose em TMC6 (setas vermelhas). O Paciente 25 também apresentou deleção no gene STRC. (B) Estudos de segregação da alteração no gene TMC6 nas famílias dos pacientes, indicando que a deleção era supostamente de novo nos dois casos.

Para validar as deleções detectadas por MLPA, o material dos Pacientes 25 e 29 foi novamente estudado por array-CGH, dessa vez pela plataforma de oligoarrays de 44k. Essa etapa foi realizada pela Dra. Erika Freitas, pesquisadora da equipe da Dra. Carla Rosenberg. A plataforma possui duas sondas que hibridam em TMC6, localizadas nos íntrons 4 e 13. Nenhuma alteração foi detectada dentro do intervalo correspondente a TMC6 e, naquele momento, isso indicava que a deleção não abrangia todo o gene. 
Com o objetivo de verificar a existência de mutações de ponto ou detectar pontos de quebra, sequenciamos nos dois pacientes os éxons do gene TMC6, exceto o éxon 1, não codificador de aminoácidos. O resultado do sequenciamento foi normal para ambos, exceto por uma variante detectada em heterozigose no éxon 10 do Paciente 25, herdada de sua mãe. A variante, c.1280C $>$ T, não foi descrita até o momento. Triamos a variante por PCR-RFLP e ela não foi vista em 100 indivíduos controle.

Após a análise por oligoarrays e sequenciamento do material dos Pacientes 25 e 29, surgiram mais quatro casos de deleção em heterozigose nos Pacientes 27, 117, 134 e 159 (Tabela XI - p. 56). Em dois casos (Pacientes 27 e 117) não foi possível estudar a segregação da alteração. Nos dois casos restantes, em um deles a deleção foi herdada da mãe normal (Paciente 134) e no outro, de ambos os genitores normais, consanguíneos (Paciente 159). Simultaneamente, observamos três casos de deleção em heterozigose em indivíduos da amostra controle (Tabela XII - p. 56). A ocorrência de mais quatro casos de alteração em TMC6 na casuística e três na amostra controle nos fez suspeitar que se tratasse de um polimorfismo frequente ou que houvesse problemas com a sonda de MLPA.

Para verificar possíveis problemas com a sonda, desenhada a partir do éxon 17, decidimos alinhar novamente sua sequência utilizando a ferramenta BLAT do UCSC Genome Browser (http://genome.ucsc.edu/cgi-bin/hgBlat?command=start). Surpreendentemente, ao alinharmos a sequência com o genoma de referência atual (GRCh37/hg19), verificamos grande homologia da sonda com outra região do cromossomo 2 (Fig. 11), o que não acontecia com a versão do genoma humano de referência utilizada como base para sua construção (NCBI36/hg18). Além da alta homologia com a região do cromossomo $2 \mathrm{em}$ grande parte da sonda, a correspondência total dos nucleotídeos que existia na região de ligação poderia fazer com que ela se hibridasse tanto no éxon 17 de TMC6 quanto na sequência do cromossomo 2. Diferenças na intensidade de hibridação com o cromossomo 2 entre diferentes indivíduos devem ter sido refletidas na amplificação dos fragmentos, levando a um resultado falso-positivo de deleção em heterozigose em alguns indivíduos. 


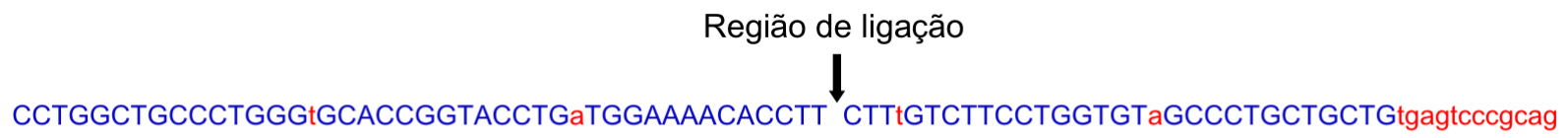

Sequência proximal

Sequência distal

Fig. 11. Alinhamento da sequência da sonda para TMC6, desenhada no éxon 17, com outra região do cromossomo 2 usando o genoma de referência GRCh37/hg19. As letras maiúsculas em azul representam as bases do éxon 17 de TMC6 nas quais há correspondência com as bases da região do cromossomo 2 homóloga. As bases sem correspondência são representadas pelas letras minúsculas em vermelho. A seta indica a região de ligação entre as sequências proximal e distal da sonda.

Para confirmar a suspeita de que as alterações detectadas em TMC6 seriam artefatos, desenhamos mais duas sondas de MLPA tendo como alvo de hibridação os éxons adjacentes à primeira sonda desenhada, ou seja, 16 e 18, que distam respectivamente 157 e 120 pb. Não foi possível realizar esse teste no Paciente 29 pois seu material havia se esgotado. De fato, as duas novas sondas deram como resultado número normal de cópias de TMC6 em todos os pacientes com a suposta deleção em TMC6 (Tabela XIII) e demais indivíduos com a mesma suposta deleção, incluindo os controles e os genitores que foram testados. Concluímos que os resultados de deleção em heterozigose de TMC6 eram realmente artefatos.

Tabela XIII. Resultado de MLPA para três sondas no gene TMC6 em cinco dos seis pacientes da casuística com suposto resultado inicial de deleção.

\begin{tabular}{llll}
\hline Paciente & Sonda éxon $\mathbf{1 6}$ & Sonda éxon $\mathbf{1 7}$ & Sonda éxon $\mathbf{1 8}$ \\
\hline Paciente 25 & 1,02 & 0,58 & 1,02 \\
Paciente 27 & 1,00 & 0,50 & 0,99 \\
Paciente 117 & 1,12 & 0,62 & 1,01 \\
Paciente 134 & 1,08 & 0,56 & 1,01 \\
Paciente 159 & 1,00 & 0,57 & 0,98 \\
\hline
\end{tabular}

Por analogia ao papel do gene TMC1 (DFNA36 e DFNB7/11), pertencente à mesma família gênica, não é possível descartar completamente a hipótese de que haja relação entre TMC6 e surdez. Até o momento, mutações no gene TMC6 foram associadas à epidermodisplasia verruciforme, doença que se caracteriza por um aumento da susceptibilidade à infecção por alguns dos papilomavírus humanos, o que leva a um alto risco de desenvolvimento de câncer de pele (Ramoz e col., 2002). De 
acordo com o banco de dados Unigene, seu ortólogo murino Tmc6 possui expressão na orelha interna de camundongos, entre outros tecidos, o que poderia sugerir relação com surdez. Nosso estudo, entretanto, não reforçou essa hipótese.

\section{IV.4.2. Investigação das alterações no gene $S T R C$}

Em nossa casuística, detectamos sete alterações no gene STRC: seis deleções em heterozigose e uma duplicação (Tabela XI, p. 56). Três desses pacientes (20, 25 e 41) são sindrômicos, sendo que os Pacientes 20 e 25 haviam sido previamente estudados por array-CGH de $1 \mathrm{Mb}$. É provável que, nesses pacientes, os rearranjos englobando o gene STRC devem possuir tamanho bem menor que a extensão do clone RP11-263I19, que hibrida nessa região, e não foram detectados por essa técnica.

O Paciente 20 tem como sinais retardo mental e baixa estatura, além de surdez sensorioneural, pós-lingual, bilateral e de grau grave. O Paciente 25 apresenta hipoplasia renal direita, dismorfismo facial com hipertelorismo, ânus imperfurado e atraso no desenvolvimento neuropsicomotor. Quanto à surdez, é sensorioneural, bilateral e grave. Por fim, o Paciente 41 possui surdez mista, pós-lingual, unilateral e de grau moderado. Seus sinais clínicos incluem face alongada, prognatismo, palato alto e leve dificuldade de compreensão de fala e escrita.

Os quatro casos restantes são de pacientes não-sindrômicos $(97,119,128$ e 146), em cujas famílias segrega surdez de provável herança recessiva (três casos) e dominante (um caso). A Fig. 12 traz as genealogias dos quatro casos familiais. A Família 146 foi classificada como apresentando surdez recessiva pois o pai (Fig. 12-D, II-7), com surdez sensorioneural unilateral, afirmou acreditar que sua perda foi devida a um acidente.

O estudo de segregação das alterações em STRC foi possível somente nas famílias dos Pacientes 25 e 146. A família do Paciente 25, caso isolado de surdez sindrômica, é a mesma em que houve suspeita não confirmada de deleção de novo no gene TMC6. Observamos que a deleção em STRC foi herdada da mãe normal. Já na família do Paciente 146 (Fig. 12-D), único caso de duplicação, todos os afetados possuem a alteração, inclusive o pai, cuja perda pode ser ambiental. A mãe revelou resultado normal. Aparentemente, a alteração segrega com a surdez e, neste caso, o mecanismo de herança seria o autossômico dominante. 
A

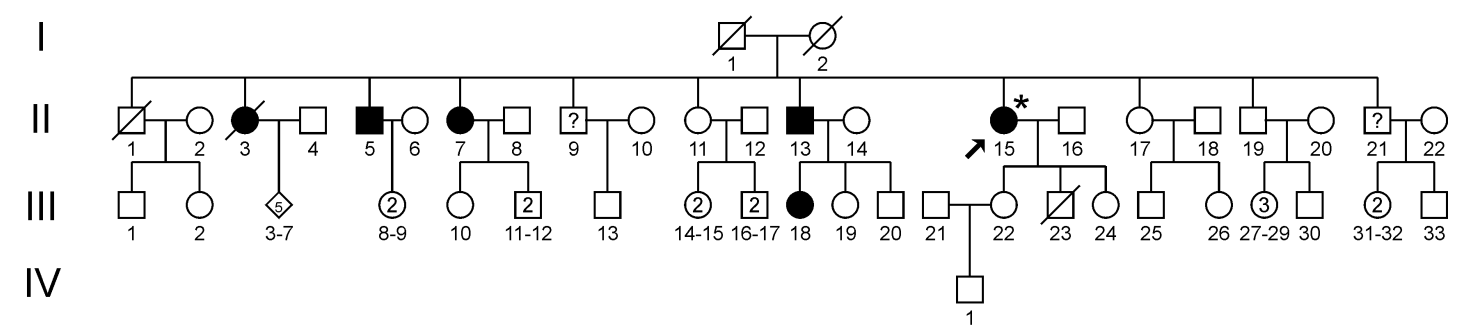

B

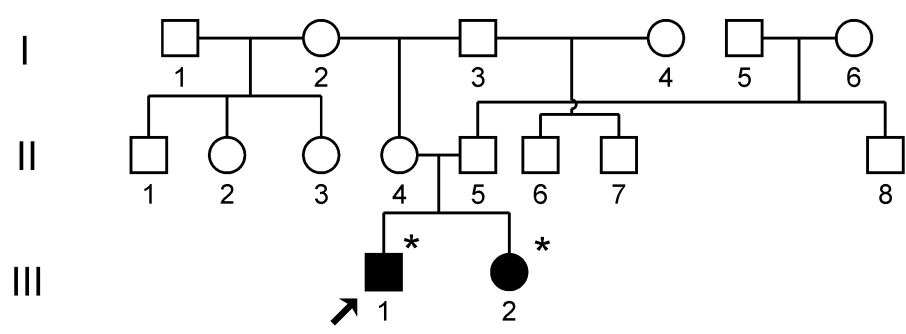

C

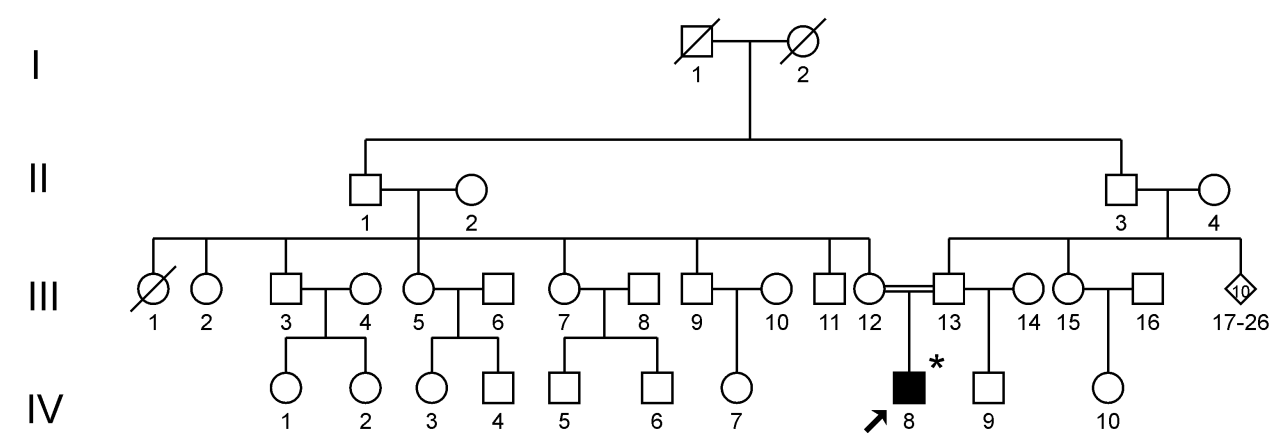

$\mathrm{D}$

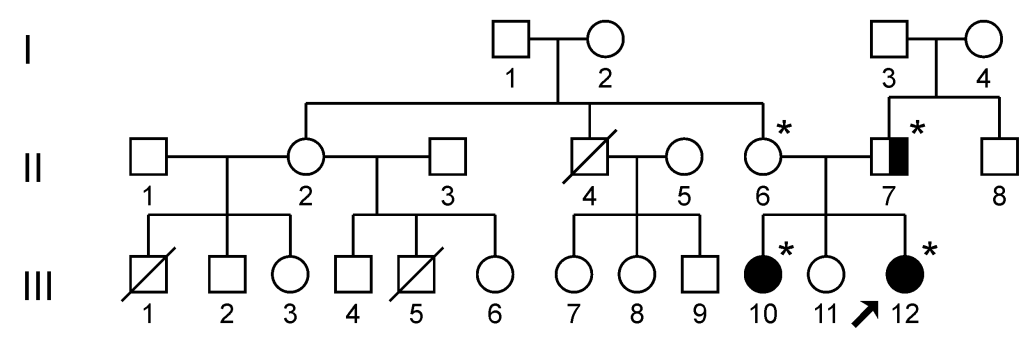

Fig. 12. Genealogias dos casos familiais de portadores de rearranjos no gene STRC. (A) Família 97; (B) Família 119; (C) Família 128; (D) Família 146. As setas indicam os propósitos e os asteriscos indicam os indivíduos com amostras submetidas a MLPA. 
Na família do Paciente 20, conseguimos obter material para estudo somente da mãe normal, cujo resultado mostrou também deleção no gene STRC. Na família do Paciente 119 (Fig. 12-B), estudamos a irmã afetada (III-2) do propósito (III-1), a qual possui número normal de cópias para STRC. Portanto, nessa família, é mais provável que a surdez não seja devida à alteração apresentada pelo propósito. Nas três famílias restantes, nenhum estudo de segregação foi conduzido por dificuldades de contato ou colaboração por parte das famílias. No caso da família do Paciente 97 (Fig. 12-A), os pais do propósito já eram falecidos.

O gene $S T R C$, que codifica uma proteína expressa nas células ciliadas sensoriais e é associada aos estereocílios, já foi previamente relacionado à surdez não-sindrômica de herança autossômica recessiva mapeada no loco DFNB16 (Campbell e col., 1997). Em 2001, Verpy e col. identificaram duas mutações frameshift e uma deleção em duas famílias afetadas por surdez ligada a DFNB16: na primeira família, consanguínea e de origem paquistanesa, foi identificada uma inserção em homozigose de 1 pb, e na segunda, originária da França e não-consanguínea, foi detectada uma deleção de 4 pb e uma deleção maior no outro alelo. O gene $S T R C$ também já foi relacionado a uma síndrome de genes contíguos envolvendo surdez e infertilidade masculina, em que os indivíduos eram homozigotos para deleção incluindo STRC e CATSPER2 (Avidan e col., 2003; Zhang e col., 2007).

Detectamos sete alterações $(4,3 \%)$ no número de cópias no gene $S T R C$ entre os afetados. Por outro lado, a frequência de alterações na amostra controle foi um pouco maior (5,8\%). De fato, o loco 15q15.3, o qual inclui STRC, é considerado de variação normal na população. Nessa região existem dois grandes blocos de LCRs (Low Copy Repeats), que podem originar deleções ou duplicações mediados por NAHR. Tais rearranjos são recorrentes nessa região: estão registradas no DGV $36 \mathrm{CNVs}$ nãopatogênicas englobando o loco 15q15.3, das quais 12 incluem o gene STRC. Com base nessas informações, é mais provável que todas as alterações que detectamos sejam polimorfismos sem efeito fenotípico.

No entanto, em trabalho mais recente, Knijnenburg e col. (2009) descreveram um paciente sindrômico portador de deleção em homozigose em 15q15.3 incluindo o gene STRC, filho de pais heterozigotos em relação à deleção. Os pais não são aparentados entre si e a deleção de cada um deles possui tamanho diferente. Com base no banco de dados DGV e triagem em indivíduos controle, foi estimada em torno de 
1,6\% a frequência de CNVs em heterozigose comprometendo essa região na população normal. Os autores concluíram que mesmo uma CNV em heterozigose tida como sem efeito fenotípico pode gerar consequências mais graves se em homozigose, enfatizando a necessidade de uma análise cuidadosa de CNVs em geral. Portanto, é possível que alguns pacientes de nossa casuística com alterações em STRC sejam portadores de uma segunda mutação que esteja levando à surdez, em composição com o rearranjo detectado.

Essa hipótese ficou em aberto, pois o rastreamento de mutações de ponto em STRC não tem se mostrado viável: em vista da grande semelhança de sequência entre o gene ativo e seu pseudogene, é extremamente difícil o sequenciamento de todos os éxons de STRC (del Castillo, comunicação pessoal). A técnica utilizada por Verpy e col. (2001), que identificaram as mutações como presentes na cópia ativa, incluía PCR de longo alcance seguida de clonagem de grandes fragmentos de DNA para incluir segmentos com sequência que permitisse distinguir o gene do pseudogene. Esse procedimento, além de muito trabalhoso, pode ser ineficiente porque as duas cópias são praticamente idênticas entre si na metade 5' do gene (éxons de 1 a 15). Logo, mutações presentes nessa porção, detectadas ao sequenciamento, não podem ser atribuídas com certeza ao gene ou ao pseudogene.

\section{IV.4.3. Investigação da alteração no gene $I M M P 2 L$}

Em nossa casuística detectamos uma paciente (Paciente 78) com duplicação no gene IMMP2L (Fig. 13-A). O estudo de segregação por meio de MLPA revelou que a mãe da paciente, também afetada por surdez não-sindrômica, é portadora de duplicação no mesmo gene, o que indica que o rearranjo foi por ela transmitido. Por sua vez, o pai possui número normal de cópias do gene IMMP2L (Fig. 13-B).

A paciente pertence a uma família na qual segrega surdez de provável herança autossômica dominante (Fig. 14). A propósita (III-3) compareceu a nosso Serviço de Aconselhamento Genético em 2002, aos nove anos de idade. Sua perda auditiva é prélingual, bilateral, sensorioneural e grave. A mãe (II-7) da paciente também possui surdez bilateral e sensorioneural. Contudo, o grau da perda é leve. O déficit de audição foi percebido aproximadamente aos 34 anos de idade. Na ficha de anamnese da família constam referências, não confirmadas por estudo audiológico, a casos de surdez no lado materno: a mãe da paciente afirmou possuir parentes distantes do lado paterno que 
perderam a audição em idade mais avançada e primas, também do lado paterno, que teriam nascido com surdez de grau leve ou moderado, que ainda permitiu o desenvolvimento da linguagem. Todos os familiares referidos pela mãe residem no estado da Bahia, o que impediu estudo de segregação mais aprofundado.

A

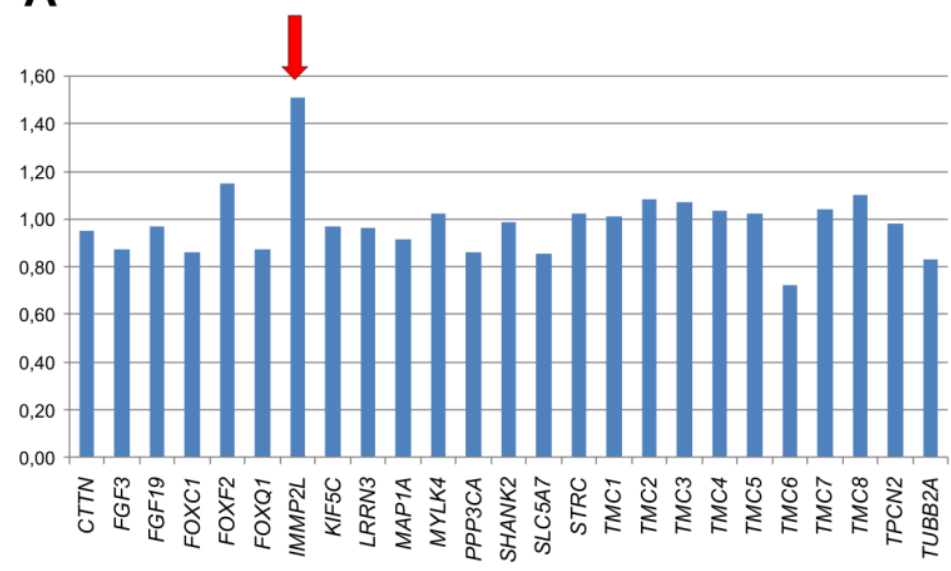

B

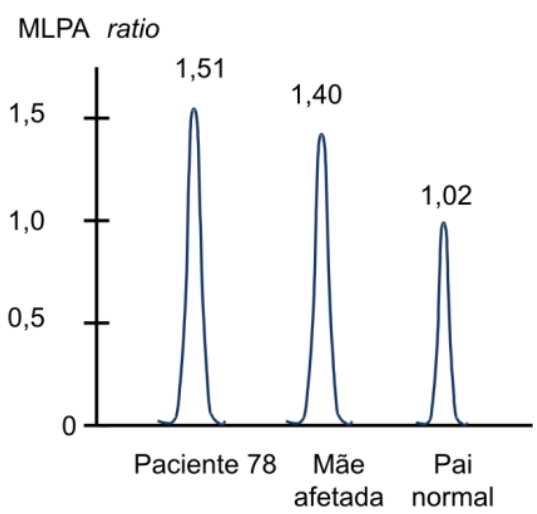

Fig. 13. Duplicação no gene IMMP2L na Paciente 78. (A) Perfil das 25 sondas de MLPA na paciente, com destaque para a duplicação em IMMP2L (seta vermelha). (B) Estudo de segregação da duplicação no gene IMMP2L na família da paciente, em que se observou que o rearranjo foi herdado da mãe afetada.

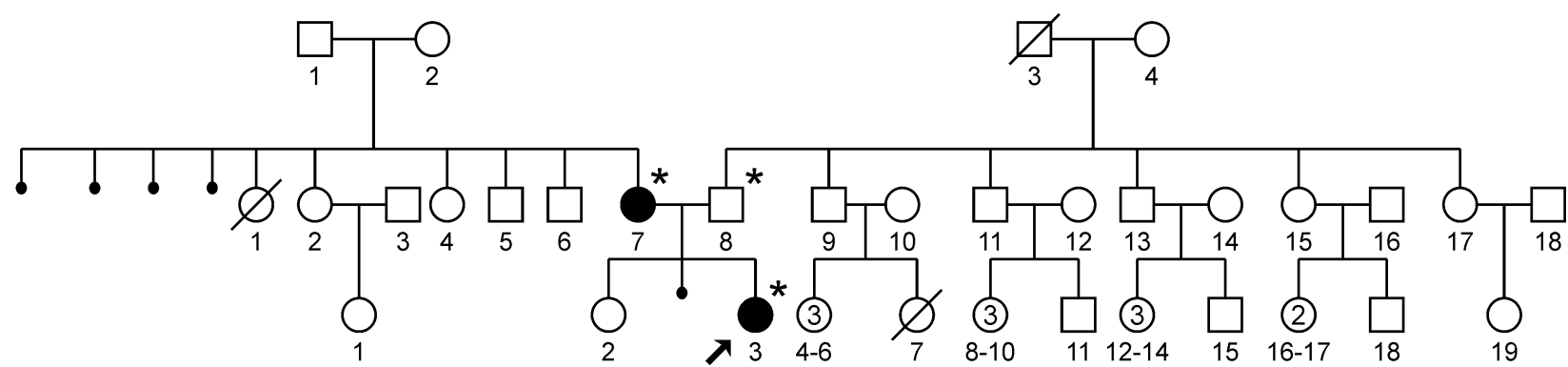

Fig. 14. Genealogia da família da Paciente 78. A seta indica a propósita e os asteriscos indicam os indivíduos com amostras submetidas a MLPA.

Para validar o resultado de MLPA observado, desenhamos outra sonda para IMMP2L. A primeira sonda fora desenhada a partir do éxon 2 e, para esta etapa, 
desenhamos nova sonda a partir do éxon 1. A nova sonda revelou também duplicação na paciente e em sua mãe.

Com exceção do primeiro éxon, não codificador de aminoácidos, todos os éxons de IMMP2L foram sequenciados na paciente e sua mãe para buscar um possível ponto de quebra em região codificadora. O sequenciamento de todos os éxons das amostras de ambas deu resultado normal.

O material da Paciente 78 foi também submetido a array-CGH para se verificar a extensão e possível ponto de quebra do rearranjo. Esse procedimento foi realizado mais uma vez com a colaboração da Dra. Erika Freitas. A plataforma utilizada foi o oligoarray da Agilent Technologies que contém quatro áreas de aproximadamente 180.000 oligonucleotídeos (4x180k). O resultado de array-CGH indicou duplicação de 36 sondas entre 110,730,380 - 111,169,042 (Fig. 15).

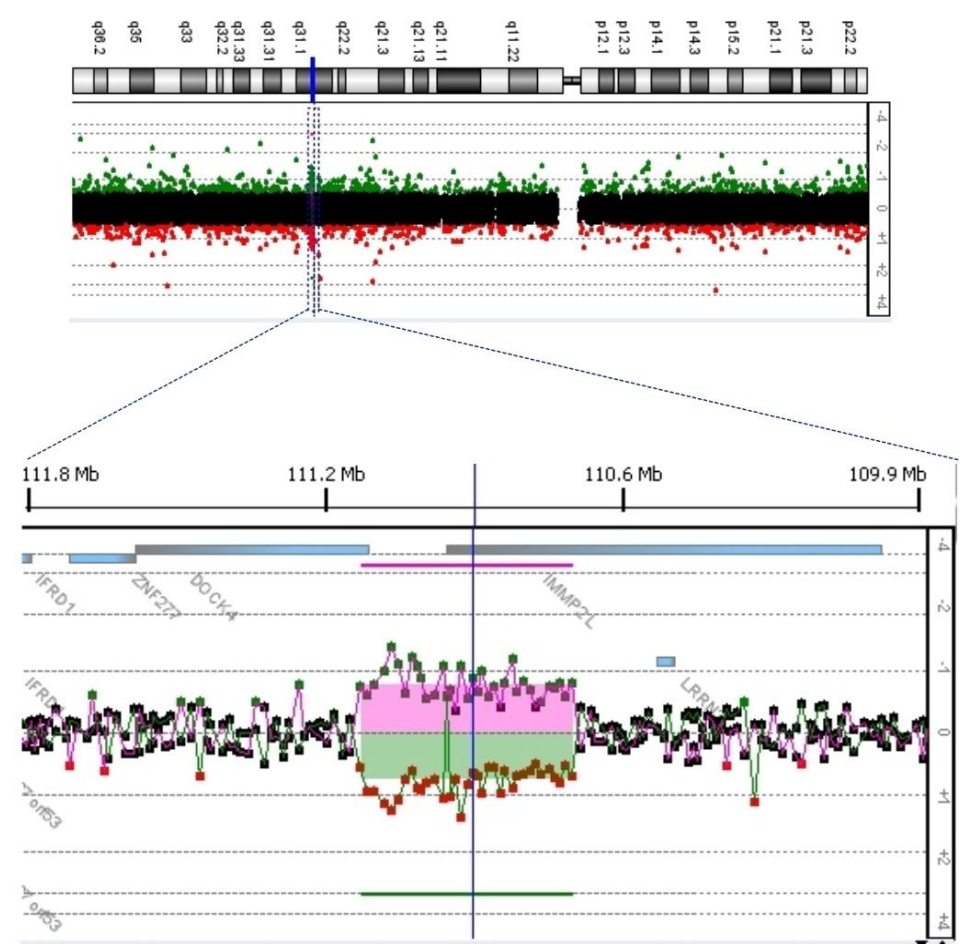

Fig. 15. Perfil da duplicação em 7q31.1 da Paciente 78 por array-CGH de 180k, mostrando o resultado alterado em 36 sondas.

A duplicação da paciente possui pelo menos $438 \mathrm{~kb}$. Esse rearranjo abrange os éxons 1, 2 e 3 do gene IMMP2L e também a porção 3' de outro gene, DOCK4, pelo menos os éxons de 45 a 52. A partir do posicionamento das mais extremas sondas, 
distal e proximal, duplicadas, e as primeiras sondas não-duplicadas a elas adjacentes, foi possível inferir que o ponto de quebra proximal da duplicação está certamente localizado em região do íntron 3 de IMMP2L e o ponto de quebra distal, entre o éxon 38 e o íntron 44 do gene DOCK4 (Fig. 16).

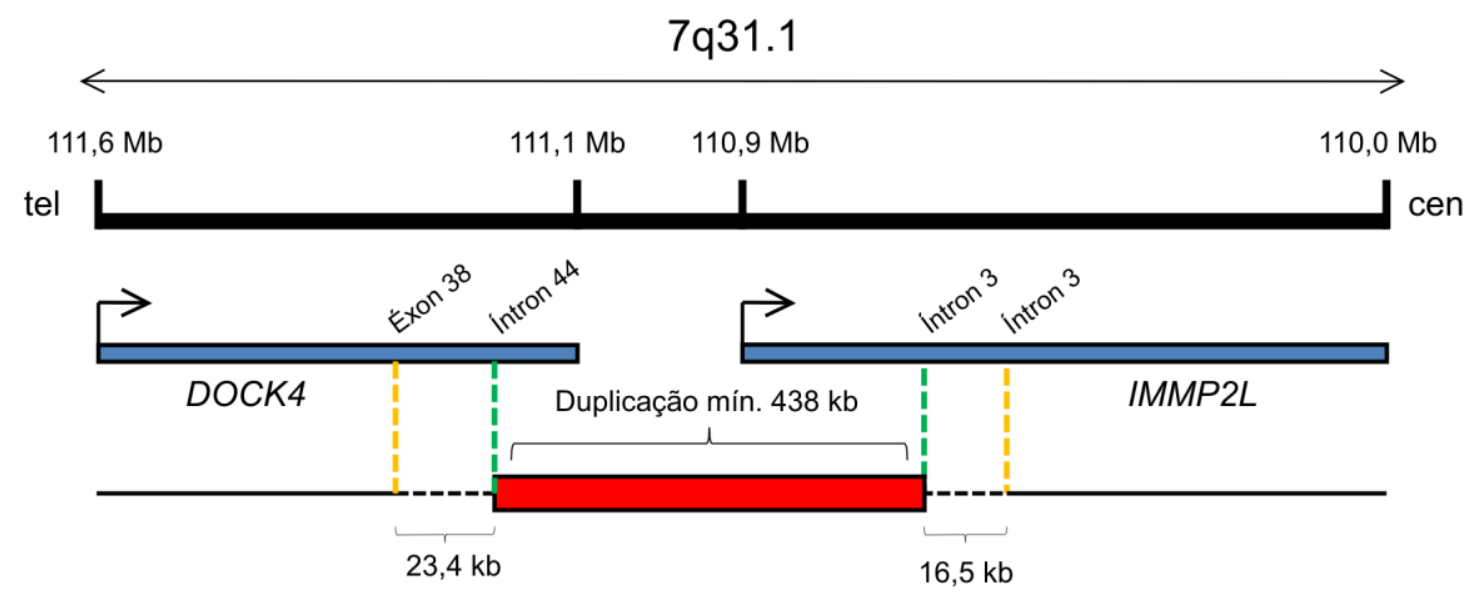

Fig. 16. Esquema ilustrando o mapeamento da duplicação na Paciente $78 \mathrm{em} 7 \mathrm{q} 31.1$ por meio de oligoarrays de 180k. A duplicação, de no mínimo 438 kb, engloba os éxons 1, 2 e 3 do gene IMMP2L e pelo menos os éxons 45 a 52 do gene DOCK4. As linhas pretas tracejadas simbolizam as regiões em que podem se localizar os pontos de quebra proximal e distal e que não são cobertas pelas sondas. As linhas verdes tracejadas indicam as localizações correspondentes, em cada gene, às últimas sondas duplicadas, e as linhas amarelas tracejadas, às primeiras sondas não duplicadas. Cen: centrômero; tel: telômero.

\section{IV.4.3.1. Os genes IMMP2L e DOCK4}

O gene IMMP2L (Inner Mitochondrial Membrane Peptidase 2-Like) codifica uma proteína homóloga à proteína Imp2p de levedura. O produto do gene, uma protease, tem a função de catalisar a remoção de peptídeos transitórios necessários para o direcionamento de proteínas da matriz mitocondrial ao espaço intermembrana através da membrana interna (Nunnari e col., 1993). Uma mutação em homozigose em Immp2l leva à disfunção mitocondrial e reprodutiva em camundongos ( $\mathrm{Lu}$ e col., 2008). Portanto, IMMP2L parece ter uma importante função mitocondrial, essencial ao funcionamento adequado de órgãos e tecidos com alta demanda energética.

Rearranjos no loco 7q31 têm sido associados a comportamento autístico e à síndrome Gilles de la Tourette (OMIM \#137580) (Kroisel e col., 2001; Petek e col., 2001; Tyson e col., 2004). Petek e col. (2001) identificaram uma duplicação de novo entre 7q22.1-31.1, em que o ponto de quebra distal localizava-se no gene IMMP2L. 
Posteriormente, o mesmo grupo conduziu estudos moleculares em 39 pacientes portadores da síndrome Gilles de la Tourette e em 95 pacientes com autismo, mas não encontraram nenhuma mutação de ponto em IMMP2L (Petek e col., 2007).

O Paciente 7, cujo resultado de array-CGH de $1 \mathrm{Mb}$ nos fez selecionar IMMP2L como candidato à surdez para nosso estudo, apresentava, além de surdez sensorioneural moderada à esquerda e grave à direita, atraso de desenvolvimento, hipertelorismo, dedos curtos e grossos, entre outros sinais. Seu resultado de array-CGH de 44k revelou deleção cujo tamanho máximo estimado incluiria os éxons de 4 a 6 de IMMP2L e tamanho mínimo que incluiria somente o éxon 6 (Catelani, 2010). Sequenciamos o gene nesse paciente e em sua mãe normal, de quem o rearranjo foi herdado. Foi detectada somente uma variante em heterozigose na mãe, c.778A $>\mathrm{G}$ no éxon 5, não descrita. Esse dado indica que talvez a deleção seja bem menor do que havia sido especulado, comprometendo somente o éxon 6.

No DECIPHER, além do caso do Paciente 7 (USP00002391), existem mais oito registros de rearranjos em IMMP2L levando a fenótipos clínicos. A maioria dos registros é de novo, cujos casos clínicos incluem autismo, atraso da fala e retardo mental como sinais mais proeminentes. Nenhum deles possui surdez. Já no DGV, observamos grande número de CNVs envolvendo IMMP2L: existem 56 variantes catalogadas, em sua maioria deleções. Em nossa amostra controle, detectamos três indivíduos (1,6\%) com deleção em heterozigose em IMMP2L, consistente com a ideia de que essas alterações sejam polimórficas e sem efeito. Em vista dessas informações, é pouco provável que o rearranjo detectado por array-CGH no Paciente 7 , herdado de sua mãe normal, seja a causa da surdez e/ou dos sinais associados por ele apresentados.

A duplicação presente na Paciente 78 tem seu ponto de quebra proximal no íntron 3 de IMMP2L. O grande número catalogado no DGV de CNVs benignas que incluem esse gene, embora com poucas duplicações registradas, é forte indício de que a duplicação em IMMP2L não seja a causa da surdez da paciente. Entretanto, a duplicação foi herdada da mãe, também afetada, e isso tornaria tentador especular que IMMP2L estivesse implicado na surdez apresentada por ambas. No entanto, o rearranjo da paciente inclui também parte de outro gene, DOCK4, fato que nos fez investigar na literatura sua função.

O gene DOCK4, clonado e identificado por Yajnik e col. (2003), é membro da família DOCK (Dedicator of Cytokinesis) e codifica uma proteína com um domínio DHR-1, 
DHR-2 e SH3, além de outros três motivos em sua porção mais terminal. Essa proteína funciona como um GEF (Guanine nucleotide Exchange Factor), isto é, regula as GTPases da família Rho, que estão relacionadas à motilidade, invasão e adesão celular ao coordenar a reunião do citoesqueleto de actina. Ao identificar mutações em DOCK4 em linhagens de células humanas cancerosas, Yajnik e col. (2003) atribuíram ao gene importância na tumorigênese, além da regulação das junções intercelulares. Um estudo mais recente identificou, por meio de arrays de SNPs, deleções em homozigose em DOCK4 em linhagens celulares de carcinoma seroso ovariano de alto grau; logo, DOCK4 seria um gene candidato a supressor de tumor (Kuo e col., 2009). Outros trabalhos recentes também têm sugerido associação de DOCK4 com autismo (Maestrini e col., 2010; Pagnamenta e col., 2010; Risheg e col., 2010). Ueda e col. (2008) demonstraram que Dock4 regula o desenvolvimento dendrítico em neurônios do hipocampo, ressaltando um papel desse gene na conectividade neuronal adequada.

A informação acerca de DOCK4 mais relevante para nosso estudo veio do trabalho de Yan e col. (2006), que identificaram uma isoforma de seu produto protéico que se localiza nos estereocílios e se liga à harmonina (USH1C), proteína de importância-chave no desenvolvimento dos estereocílios (Adato e col., 2005). Mutações no gene USH1C causam a síndrome de Usher tipo 1C (Verpy e col., 2000), que combina surdez à retinose pigmentar, ou ainda surdez não-sindrômica de herança autossômica recessiva, loco nomeado de DFNB18 (Ahmed e col., 2002). Portanto, a interação com a harmonina parece tornar a relação de DOCK4 com surdez muito mais significativa do que a especulada em relação a IMMP2L.

A isoforma de DOCK4 identificada por Yan e col. (2006) não possui os aminoácidos correspondentes ao éxon 49 (DOCK4-Ex49) e interage com o domínio PDZ1 da harmonina. Enquanto DOCK4 está presente em vários tecidos humanos, a isoforma DOCK4-Ex49 é expressa especificamente no cérebro e no olho. Os autores demonstraram ainda que tanto essa isoforma quanto a forma mais comum de DOCK4 se ligam e ativam a GTPase Rac. Porém, a isoforma DOCK4-Ex49 aumenta a ativação de Rac em nível extremamente elevado, se comparada à outra. Em camundongos, experimentos indicaram que DOCK4-Ex49 e a harmonina possuem localização similar nos estereocílios das células ciliadas da cóclea. Com esses dados, os autores sugeriram a existência de uma via de sinalização Rac-DOCK4-harmonina na orelha interna para a regulação da organização do citoesqueleto de actina nos estereocílios. 
A duplicação na Paciente 78 engloba com certeza os éxons de 45 a 52 de DOCK4. Se a duplicação estiver em tandem, existem duas cópias do éxon 49 em um mesmo alelo. Esse rearranjo poderia alterar o splicing da isoforma DOCK4-Ex49, levando à formação de um produto não funcional ou ainda um produto que retém o éxon 49 na cóclea. Dessa maneira, é possível que a quantidade da isoforma DOCK4Ex49 funcional nos estereocílios esteja reduzida, uma vez que ela seria codificada somente a partir do alelo normal, acarretando haploinsuficiência. Nossa hipótese é a de que a duplicação comprometendo a porção terminal de DOCK4 estaria relacionada à etiologia da surdez apresentada pela Paciente 78 e, por conseguinte, DOCK4 seria um novo gene responsável por surdez.

Apesar de a relação de DOCK4 com a audição ser a mais plausível dentro de nossa hipótese, um papel de IMMP2L na audição não pode ser definitivamente descartado. O grande número de mutações que causam surdez já descritas no DNA mitocondrial nos adverte que genes com função mitocondrial não devem ser ignorados, ainda que nenhum gene nuclear com tal função tenha sido associado à surdez até o momento. Outra informação favorável é o fato de IMMP2L possuir expressão na cóclea, segundo o Morton Fetal Cochlea.

Existem sete registros de CNV no DECIPHER incluindo partes de DOCK4 e que incluem também IMMP2L. Seis deles são deleções, a maioria relacionadas com autismo, como já mencionado, e há somente um caso de uma grande duplicação de 36 $\mathrm{Mb}$ em um paciente com autismo e atraso na fala, além de vários outros sinais clínicos, mas surdez não foi mencionada. Em contraste com o grande número de CNVs englobando IMMP2L cadastradas no DGV, existem somente quatro que incluem DOCK4, em que três são deleções (Fig. 17). É curioso notar que nenhuma dessas CNVs abrangem a porção 3' de DOCK4, na qual se insere o éxon 49. Além disso, não foi descrita até o momento qualquer CNV no DGV que abrangesse tanto IMMP2L quanto DOCK4, como no caso da Paciente 78. Esses dados reforçam a idéia de que o rearranjo desta paciente possa ser responsável por seu fenótipo.

Em um dos estudos recentes que associou DOCK4 a autismo (Maestrini e col., 2010), uma duplicação abrangendo partes de IMMP2L e DOCK4 foi identificada em um pai normal e seu filho afetado por autismo. A duplicação inclui pelo menos os éxons 2 e 3 de IMMP2L e o éxon 52 de DOCK4. Porém, o ponto de quebra distal em DOCK4 não pôde ser definido e não se sabe se o éxon 49 está incluído no rearranjo. 


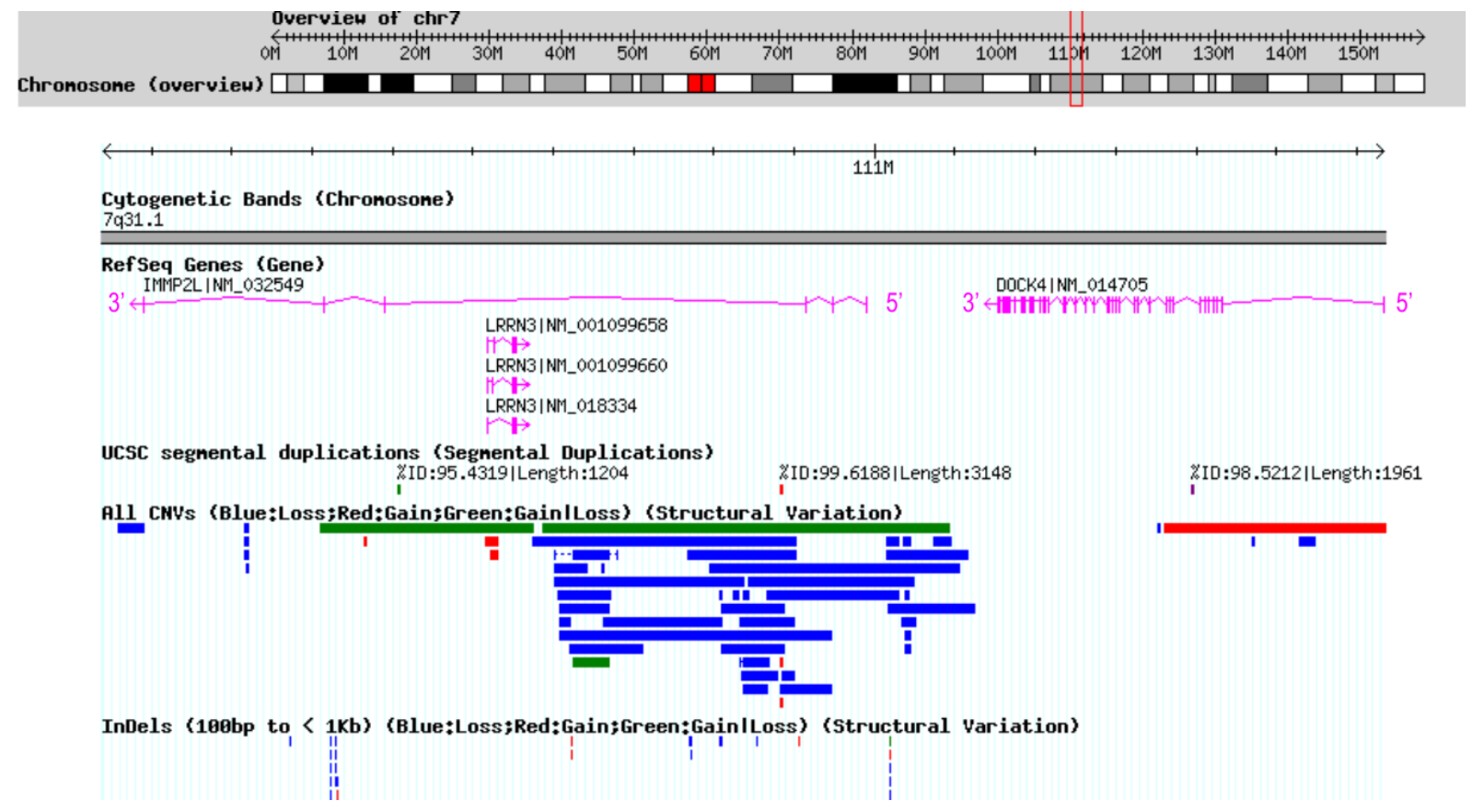

Fig. 17. CNVs catalogadas na região dos genes IMMP2L e DOCK4 em 7q31.1 e visualizadas pelo genome browser do banco de dados DGV. Observa-se a ocorrência de várias CNVs, principalmente deleções (em azul), abrangendo IMMP2L. Por outro lado, quatro CNVs incluem DOCK4, nenhuma abrangendo sua porção 3', em que três delas são deleções (em azul) e uma duplicação (em vermelho).

Por fim, verificamos na literatura se existe algum loco de surdez já mapeado na região dos genes IMMP2L e DOCK4. De fato, três locos de surdez de herança autossômica recessiva foram mapeados em 7q31: DFNB4 (Baldwin e col., 1995), DFNB14 (Mustapha e col., 1998) e DFNB17 (Greinwald e col., 1998). O único com gene identificado é o DFNB4, que corresponde ao gene SLC26A4. Mutações em SLC26A4 são responsáveis pela síndrome de Pendred ou por surdez não-sindrômica que pode estar associada a uma malformação da orelha interna, o aqueduto vestibular alargado (AVA) (Everett e col., 1997; Li e col., 1998). A síndrome de Pendred (OMIM \#274600) caracteriza-se por surdez sensorioneural, malformações como AVA e/ou displasia de Mondini e bócio de manifestação tardia.

O loco DFNB4 foi inicialmente mapeado em uma família druso-israelense com surdez não-sindrômica, delimitado pelos marcadores D7S501 e D7S523 (Baldwin e col., 1995), região que poderia incluir IMMP2L e/ou DOCK4 (Fig. 18). Mais tarde, os afetados dessa família desenvolveram bócio, indicando que na realidade tratava-se de casos da síndrome de Pendred. Abe e col. (1999) estudaram famílias com surdez associada a AVA e mapearam o loco na mesma região, porém flanqueado pelos 
marcadores D7S501 e D7S2425. Posteriormente, mutações em SLC26A4 foram rastreadas e encontradas nessas famílias (Usami e col., 1999), indicando que esse loco seria na realidade o mesmo loco DFNB4 mapeado por Baldwin e col. (1995).

Apesar de existirem casos de famílias com surdez ligadas a DFNB4 sem mutações em SLC26A4 e sem evidências dos sinais associados da síndrome de Pendred ou AVA (Pera e col., 2008), IMMP2L e DOCK4 certamente não estão envolvidos com DFNB4, pois o trabalho de Abe e col. (1999) redefiniu o loco com um intervalo que não inclui os dois genes (Fig. 18). Além disso, os intervalos críticos de DFNB14 e DFNB17 também não se sobrepõem a IMMP2L ou DOCK4 e, portanto, esses genes também não devem ter relação com esses locos. Logo, se DOCK4 for um novo gene de surdez, ele não corresponde aos locos já conhecidos e mapeados em 7q31.1.

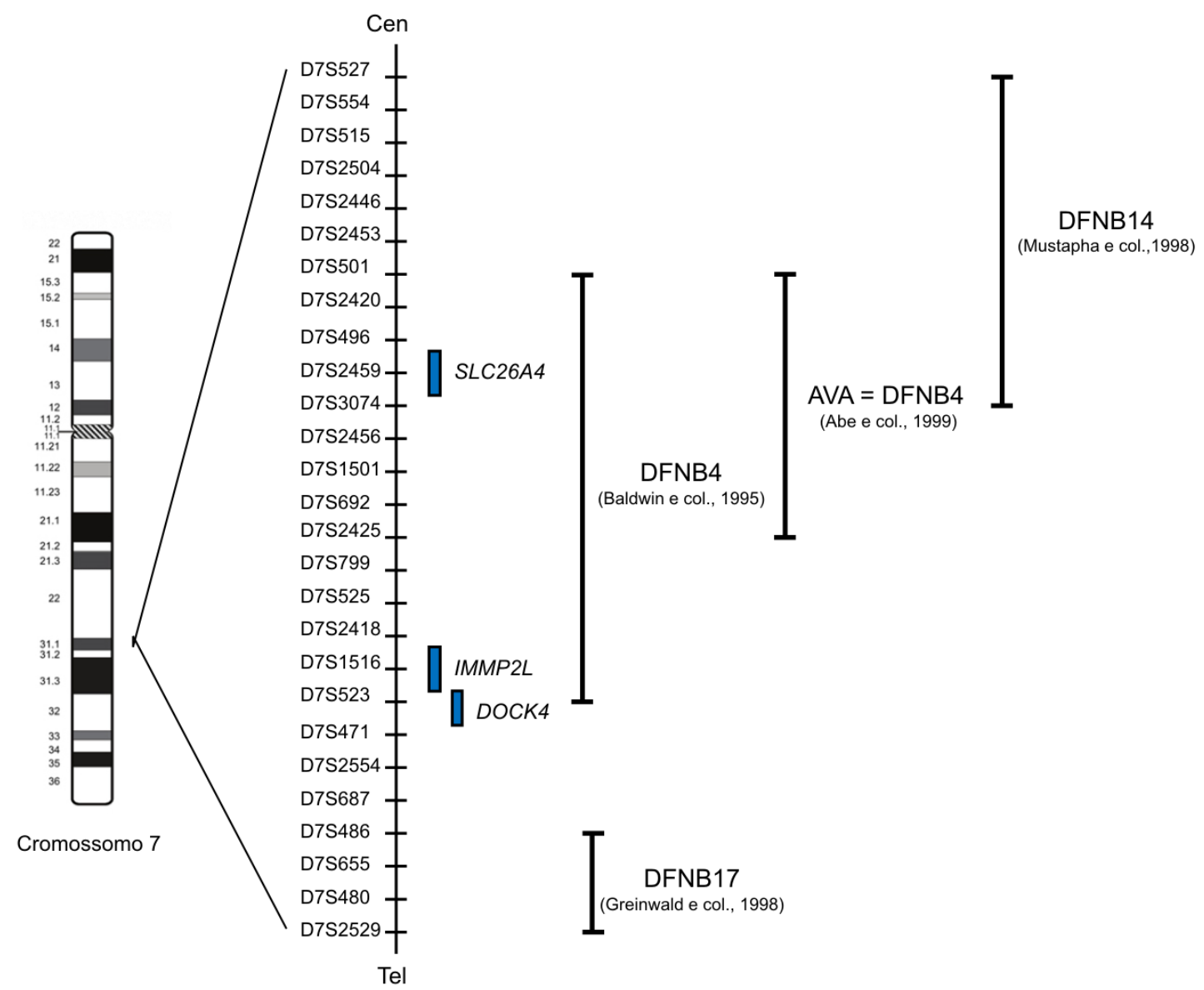

Fig. 18. Representação esquemática de parte da região 7q31.1, mostrando os marcadores do tipo microssatélite no segmento destacado, intervalos para DFNB4, DFNB14, DFNB17 e AVA (= DFNB4) e a localização dos genes SLC26A4, IMMP2L e DOCK4 (barras azuis). Os intervalos entre os marcadores não refletem a real distância entre eles. Cen: centrômero; tel: telômero; AVA: aqueduto vestibular alargado. 


\section{IV.5. Conclusões}

A partir de sete alterações detectadas por array-CGH em indivíduos com surdez associada a outros sinais, cujo quadro não permitiu classificar em síndrome conhecida (Catelani, 2010), e dados da literatura, selecionamos 25 genes candidatos à surdez e triamos microdeleções e microduplicações em outros pacientes com surdez sindrômica e não-sindrômica. A técnica utilizada para triagem, MLPA, mostrou-se muito eficiente e de fácil execução, razão pela qual é muito apropriada para a triagem rápida de microrrearranjos. Essa técnica também se revelou muito útil para validar e completar resultados de array-CGH devido à sua alta especificidade de sequência. De fato, MLPA tem sido utilizada rotineiramente por alguns centros para validar casos de alterações detectadas por array-CGH (Hills e col., 2010). Porém, nossa experiência revelou a necessidade de diversos cuidados na construção das sondas pois, do contrário, uma sonda pode gerar artefatos, como aconteceu no caso da sonda do gene TMC6.

Detectamos alterações nos genes IMMP2L e STRC em nossa casuística de 163 indivíduos, mas não nos outros 23 genes testados. É possível que alguns desses 23 genes não tenham efetivamente papel algum na audição ou que alterações no número de cópias nesses genes sejam muito raras. Além disso, devemos salientar que foi desenhada somente uma sonda por gene candidato. É possível que alguns pacientes tenham alterações em regiões desses genes não detectáveis pelas sondas que foram construídas. Entretanto, a construção de várias sondas para cada um dos 25 genes candidatos em nosso estudo teria sido de elevado custo e reduziria o número de genes triados.

As alterações detectadas na casuística que incluem os dois genes, IMMP2L e STRC, estão em regiões com grande número de CNVs polimórficas já descritas. De fato, alterações nos dois genes foram observadas em nossa amostra controle. A probabilidade de a alteração ser causa da surdez em seus portadores fica, portanto, reduzida. Porém, deve-se levar em conta que pode haver em alguns pacientes mutações de ponto que não puderam ser rastreadas e que poderiam contribuir ao fenótipo.

Nosso resultado mais notável foi o caso da duplicação que engloba parte de dois genes em 7q31.1, IMMP2L e DOCK4. Além disso, a duplicação foi herdada da mãe da propósita igualmente afetada por deficiência auditiva. O gene DOCK4 possui uma isoforma que se localiza nos estereocílios das células ciliadas e interage com uma 
importante proteína relacionada à audição, a harmonina. Essa informação é suficiente para fazer suspeitar que DOCK4 seja um novo gene responsável por surdez. A associação de IMMP2L com surdez é menos provável, devido ao grande número de CNVs não patogênicas que incluem partes desse gene.

Estudos que permitam um mapeamento mais preciso dessa duplicação são necessários. Uma estratégia a ser considerada é a utilização de PCR quantitativo em tempo real, que poderia auxiliar no mapeamento dos pontos de quebra. O sequenciamento dos éxons de DOCK4 localizados na região de 23,4 kb em que se localiza o ponto de quebra distal da duplicação também seria recomendado. Esses serão os próximos passos dessa investigação. A investigação de outras famílias estudadas em nosso laboratório - especialmente as com padrão de herança autossômica dominante pelas mesmas técnicas mencionadas, seria igualmente indicada para confirmar o suposto papel de DOCK4 na etologia da surdez. A confirmação de DOCK4 como gene de surdez reforçaria os indícios de papel importante desse gene na função dos estereocílios, como já indicada por Yan e col. (2006).

Nossos resultados reiteram a validade de se buscar novos genes de doenças por meio do estudo de alterações no número de cópias. Por outro lado, também ficou evidente nesse estudo que muitos cuidados devem ser seguidos antes de se correlacionar uma $\mathrm{CNV}$ à causa de um determinado fenótipo. 


\section{REFERÊNCIAS BIBLIOGRÁFICAS}




\section{REFERÊNCIAS BIBLIOGRÁFICAS}

Abe S, Usami S, Hoover DM, Cohn E, Shinkawa H, Kimberling WJ. Fluctuating sensorineural hearing loss associated with enlarged vestibular aqueduct maps to $7 \mathrm{q} 31$, the region containing the Pendred gene. $\mathrm{Am}$ J Med Genet. 82(4):322-8, 1999.

Abreu-Silva RS, Lezirovitz K, Braga MC, Spinelli M, Pirana S, Della-Rosa VA, Otto PA, Mingroni-Netto RC. Prevalence of the A1555G (12S rRNA) and tRNASer(UCN) mitochondrial mutations in hearingimpaired Brazilian patients. BrazJ Med Biol Res. 39(2):219-26, 2006.

Abreu-Silva RS, Rincon D, Horimoto AR, Sguillar AP, Ricardo LA, Kimura L, Batissoco AC, Auricchio MT, Otto PA, Mingroni-Netto RC. The search of a genetic basis for noise-induced hearing loss (NIHL). Ann Hum Biol. 2010 [Epub ahead of print].

Adato A, Michel V, Kikkawa Y, Reiners J, Alagramam KN, Weil D, Yonekawa H, Wolfrum U, El-Amraoui A, Petit C. Interactions in the network of Usher syndrome type 1 proteins. Hum Mol Genet. 14(3):347-56, 2005.

Ahmed ZM, Masmoudi S, Kalay E, Belyantseva IA, Mosrati MA, Collin RW, Riazuddin S, Hmani-Aifa M, Venselaar H, Kawar MN, Tlili A, van der Zwaag B, Khan SY, Ayadi L, Riazuddin SA, Morell RJ, Griffith AJ, Charfedine I, Caylan R, Oostrik J, Karaguzel A, Ghorbel A, Riazuddin S, Friedman TB, Ayadi H, Kremer H. Mutations of LRTOMT, a fusion gene with alternative reading frames, cause nonsyndromic deafness in humans. Nat Genet. 40(11):1335-40, 2008.

Ahmed ZM, Smith TN, Riazuddin S, Makishima T, Ghosh M, Bokhari S, Menon PS, Deshmukh D, Griffith AJ, Riazuddin S, Friedman TB, Wilcox ER. Nonsyndromic recessive deafness DFNB18 and Usher syndrome type IC are allelic mutations of USHIC. Hum Genet. 110(6):527-31, 2002.

Avidan N, Tamary H, Dgany O, Cattan D, Pariente A, Thulliez M, Borot N, Moati L, Barthelme A, Shalmon L, Krasnov T, Ben-Asher E, Olender T, Khen M, Yaniv I, Zaizov R, Shalev H, Delaunay J, Fellous M, Lancet D, Beckmann JS. CATSPER2, a human autosomal nonsyndromic male infertility gene. EurJ Hum Genet. 11(7):497-502, 2003.

Baldwin CT, Weiss S, Farrer LA, De Stefano AL, Adair R, Franklyn B, Kidd KK, Korostishevsky M, Bonné-Tamir B. Linkage of congenital, recessive deafness (DFNB4) to chromosome 7q31 and evidence for genetic heterogeneity in the Middle Eastern Druze population. Hum Mol Genet. (9):1637-42, 1995.

Bitner-Glindzicz M, Lindley KJ, Rutland P, Blaydon D, Smith VV, Milla PJ, Hussain K, Furth-Lavi J, Cosgrove KE, Shepherd RM, Barnes PD, O'Brien RE, Farndon PA, Sowden J, Liu X-Z, Scanlan MJ, Malcolm S, Dunne MJ, Aynsley-Green A, Glaser B. A recessive contiguous gene deletion causing infantile hyperinsulinism, enteropathy and deafness identifies the Usher type 1C gene. Nat Genet. 26:56$60,2000$.

Braga MCC, Otto PA, Spinelli M. Recurrence Risks in cases of Nonsyndromic Deafness. BrazJ Dys and Speech-ear Dis. 2:33-40, 1999.

Campbell DA, McHale DP, Brown KA, Moynihan LM, Houseman M, Karbani G, Parry G, Janjua AH, Newton V, al-Gazali L, Markham AF, Lench NJ, Mueller RF. A new locus for non-syndromal, autosomal recessive, sensorineural hearing loss (DFNB16) maps to human chromosome 15q21-q22. J Med Genet. 34(12):1015-7, 2001.

Carter NP, Fiegler H, Piper J. Comparative analysis of comparative genomic hybridization microarray technologies: report of a workshop sponsored by the Wellcome Trust. Cytometry. 49(2):43-8, 2002. 
Catelani AL, Krepischi AC, Kim CA, Kok F, Otto PA, Auricchio MT, Mazzeu JF, Uehara DT, Costa SS, Knijnenburg J, Tabith A Jr, Vianna-Morgante AM, Mingroni-Netto RC, Rosenberg C. Chromosome imbalances in syndromic hearing loss. Clin Genet. 76(5):458-64, 2009.

Catelani, ALPM. Variação no número de cópias de segmentos de DNA (CNV) em pacientes com surdez sindrômica. 155f. Tese (Doutorado em Ciências) - Instituto de Biociências, Universidade de São Paulo, São Paulo, 2010.

Davis H, Silverman RS. Hearing and deafness. New York: Rinehart \& Wiston, 1970.

DECIPHER. Database of Chromosomal Imbalance and Phenotype in Humans using Ensembl Resources. URL: <http://decipher.sanger.ac.uk>. Acesso em: 22 abr. 2008.

del Castillo F, Aguirre L, Rodríguez-Ballesteros M, Villamar M, Moreno-Pelayo M, Moreno F, del Castillo I. A novel 200-kb deletion not involving the GJB6 (connexin-30) gene at the DFNB1 locus is found in the compound heterozygous state with a GJB2 (connexin-26) mutation in subjects with autosomal recessive hearing impairment. In: 7th Molecular Biology of Hearing and Deafness, 2009, Boston. Livro de Resumos. Boston: Harvard Medical School, p.85, 2009.

del Castillo FJ, Rodríguez-Ballesteros M, Alvarez A, Hutchin T, Leonardi E, de Oliveira CA, Azaiez H, Brownstein Z, Avenarius MR, Marlin S, Pandya A, Shahin H, Siemering KR, Weil D, Wuyts W, Aguirre LA, Martín Y, Moreno-Pelayo MA, Villamar M, Avraham KB, Dahl HH, Kanaan M, Nance WE, Petit C, Smith RJ, Van Camp G, Sartorato EL, Murgia A, Moreno F, del Castillo I. A novel deletion involving the connexin-30 gene, $\operatorname{del}(\mathrm{GJB} 6-\mathrm{d} 13 \mathrm{~s} 1854)$, found in trans with mutations in the GJB2 gene (connexin-26) in subjects with DFNB1 non-syndromic hearing impairment. J Med Genet. 42(7):588-94, 2005.

del Castillo I, Villamar M, Moreno-Pelayo MA, del Castillo FJ, Alvarez A, Telleria D, Menendez I, Moreno F. A deletion involving the connexin 30 gene in nonsyndromic hearing impairment. New Eng J Med. 346:243-9, 2002.

DGV - Database of Genomic Variants. URL: <http://projects.tcag.ca/variation/>. Acesso em: 8 dez. 2009.

Dror AA, Avraham KB. Hearing loss: mechanisms revealed by genetics and cell biology. Annu Rev Genet. 43:411-37, 2009.

Ensembl. URL: <http://www.ensembl.org>. Acesso em: 9 mar. 2008.

Entrez Gene. URL: <http://www.ncbi.nlm.nih.gov/gene>. Acesso em: 9 mar. 2008.

Estivill X, Govea N, Barceló E, Badenas C, Romero E, Moral L, Scozzri R, D'Urbano L, Zeviani M, Torroni A. Familial progressive sensorineural deafness is mainly due to the mtDNA A1555G mutation and is enhanced by treatment of aminoglycosides. Am J Hum Genet. 62(1):27-35, 1998.

Everett LA, Glaser B, Beck JC, Idol JR, Buchs A, Heyman M, Adawi F, Hazani E, Nassir E, Baxevanis AD, Sheffield VC, Green ED. Pendred syndrome is caused by mutations in a putative sulphate transporter gene (PDS). Nat Genet. 17(4):411-22, 1997.

Feldmann D, Le Maréchal C, Jonard L, Thierry P, Czajka C, Couderc R, Ferec C, Denoyelle F, Marlin S, Fellmann F. A new large deletion in the DFNB1 locus causes nonsyndromic hearing loss. Eur J Med Genet. 52(4):195-200, 2009.

Fellermann K, Stange DE, Schaeffeler E, Schmalzl H, Wehkamp J, Bevins CL, Reinisch W, Teml A, Schwab M, Lichter P, Radlwimmer B, Stange EF. A chromosome 8 gene-cluster polymorphism with low human beta-defensin 2 gene copy number predisposes to Crohn disease of the colon. Am J Hum Genet. 79(3):439-48, 2006.

Feuk L, Carson AR, Scherer SW. Structural variation in the human genome. Nat Rev Genet. 7(2):85-97, 2006. 
Finsterer J, Fellinger J. Nuclear and mitochondrial genes mutated in nonsyndromic impaired hearing. Int J Pediatr Otorbinolaryngol. 69:621-47, 2005.

Genatlas. URL: <http://genatlas.medecine.univ-paris5.fr/>. Acesso em: 9 mar. 2008.

Gonzalez E, Kulkarni H, Bolivar H, Mangano A, Sanchez R, Catano G, Nibbs RJ, Freedman BI, Quinones MP, Bamshad MJ, Murthy KK, Rovin BH, Bradley W, Clark RA, Anderson SA, O'connell RJ, Agan BK, Ahuja SS, Bologna R, Sen L, Dolan MJ, Ahuja SK. The influence of CCL3L1 gene-containing segmental duplications on HIV-1/AIDS susceptibility. Science. 307:1434-40, 2005.

Greinwald JH Jr, Wayne S, Chen AH, Scott DA, Zbar RI, Kraft ML, Prasad S, Ramesh A, Coucke P, Srisailapathy CR, Lovett M, Van Camp G, Smith RJ. Localization of a novel gene for nonsyndromic hearing loss (DFNB17) to chromosome region 7q31. Am J Med Genet. 78(2):107-13, 1998.

Hilgert N, Smith RJ, Van Camp G. Forty-six genes causing nonsyndromic hearing impairment: which ones should be analyzed in DNA diagnostics? Mutat Res. 681(2-3):189-96, 2009a.

Hilgert N, Smith RJ, Van Camp G. Function and expression pattern of nonsyndromic deafness genes. Curr Mol Med. 9(5):546-64, 2009b.

Hills A, Ahn JW, Donaghue C, Thomas H, Mann K, Ogilvie CM. MLPA for confirmation of array CGH results and determination of inheritance. Mol Cytogenet. 3:19, 2010.

Hutchin TP, Cortopassi GA. Mitochondrial defects and hearing loss. Cell Mol Life Sci. 57:1927-37, 2000.

Iafrate AJ, Feuk L, Rivera MN, Listewnik ML, Donahoe PK, Qi Y, Scherer SW, Lee C. Detection of largescale variation in the human genome. Nat Genet. 36(9):949-51, 2004.

Ikeda A, Zheng QY, Zuberi AR, Johnson KR, Naggert JK, Nishina PM. Microtubule-associated protein $1 \mathrm{~A}$ is a modifier of tubby hearing (moth1). Nat Genet. 30:401-5, 2002.

Kalay E, Caylan R, Kiroglu AF, Yasar T, Collin RWJ, Heister JGAM, Oostrik J, Cremers CWRJ, Brunner HG, Karaguzel A, Kremer H. A novel locus for autosomal recessive nonsyndromic hearing impairment, DFNB63, maps to chromosome 11q13.2-q13.4. J Mol Med. 85:397-404, 2007.

Kallioniemi A, Kallioniemi OP, Sudar D, Rutovitz D, Gray JW, Waldman F, Pinkel D. Comparative genomic hybridization for molecular cytogenetic analysis of solid tumors. Science. 258:818-21, 1992.

Keats BJ, Berlin CI. Genomics and hearing impairment. Genome Res. 9(1):7-16, 1999.

Keats BJ. Genes and syndromic hearing loss. J Commun Disord. 35(4):355-66, 2002.

Khan SY, Riazuddin S, Tariq M, Anwar S, Shabbir M, Riazuddin SA, Khan SN, Husnain T, Ahmed ZM, Friedman TB, Riazuddin S. Autosomal recessive nonsyndromic deafness locus DFNB63 at chromosome 11q13.2-q13.3. Hum Genet. 120:789-93, 2007.

Kitajiri S, Makishima T, Friedman TB, Griffith AJ. A novel mutation at the DFNA36 hearing loss locus reveals a critical function and potential genotype-phenotype correlation for amino acid-572 of TMC1. Clin Genet. 71(2):148-52, 2007.

Knijnenburg J, Oberstein SA, Frei K, Lucas T, Gijsbers AC, Ruivenkamp CA, Tanke HJ, Szuhai K. A homozygous deletion of a normal variation locus in a patient with hearing loss from nonconsanguineous parents. J Med Genet. 46(6):412-417, 2009.

Kokotas H, Petersen MB, Willems PJ. Mitochondrial deafness. Clin Genet. 71:379-91, 2007.

Kroisel PM, Petek E, Emberger W, Windpassinger C, Wladika W, Wagner K. Candidate region for Gilles de la Tourette syndrome at 7q31. Am J Med Genet. 101(3):259-61, 2001. 
Kuo KT, Guan B, Feng Y, Mao TL, Chen X, Jinawath N, Wang Y, Kurman RJ, Shih IeM, Wang TL. Analysis of DNA copy number alterations in ovarian serous tumors identifies new molecular genetic changes in low-grade and high-grade carcinomas. Cancer Res. 69(9):4036-42, 2009.

Kurima K, Peters LM, Yang Y, Riazuddin S, Ahmed ZM, Naz S, Arnaud D, Drury S, Mo J, Makishima T, Ghosh M, Menon PS, Deshmukh D, Oddoux C, Ostrer H, Khan S, Riazuddin S, Deininger PL, Hampton LL, Sullivan SL, Battey JF Jr, Keats BJ, Wilcox ER, Friedman TB, Griffith AJ. Dominant and recessive deafness caused by mutations of a novel gene, TMC1, required for cochlear hair-cell function. Nat Genet. 30(3):277-84, 2002.

Ledbetter DH, Riccardi VM, Airhart SD, Strobel RJ, Keenan BS, Crawford JD. Deletions of chromosome 15 as a cause of the Prader-Willi syndrome. N Engl J Med. 304(6):325-9, 1981.

Lee C, Iafrate AJ, Brothman AR. Copy number variations and clinical cytogenetic diagnosis of constitutional disorders. Nat Genet. 39:S48-54, 2007.

Lee C, Scherer SW. The clinical context of copy number variation in the human genome. Expert Rev Mol Med. 9;12:e8, 2010.

Li XC, Everett LA, Lalwani AK, Desmukh D, Friedman TB, Green ED, Wilcox ER. A mutation in PDS causes non-syndromic recessive deafness. Nat Genet. 18(3):215-7, 1998.

Lichtner P, Konig R, Hasegawa T, Van Esch H, Meitinger T, Schuffenhauer S. An HDR (hypoparathyroidism, deafness, renal dysplasia) syndrome locus maps distal to the DiGeorge syndrome region on 10p13-14. J Med Genet. 37:33-7, 2000.

Lu B, Poirier C, Gaspar T, Gratzke C, Harrison W, Busija D, Matzuk MM, Andersson KE, Overbeek PA, Bishop CE. A mutation in the inner mitochondrial membrane peptidase 2-like gene (Immp2l) affects mitochondrial function and impairs fertility in mice. Biol Reprod. 78(4):601-10, 2008.

Lupski JR, de Oca-Luna RM, Slaugenhaupt S, Pentao L, Guzzetta V, Trask BJ, Saucedo-Cardenas O, Barker DF, Killian JM, Garcia CA, Chakravarti A, Patel PI. DNA duplication associated with CharcotMarie-Tooth disease type 1A. Cell. 66(2):219-32, 1991.

Maestrini E, Pagnamenta AT, Lamb JA, Bacchelli E, Sykes NH, Sousa I, Toma C, Barnby G, Butler H, Winchester L, Scerri TS, Minopoli F, Reichert J, Cai G, Buxbaum JD, Korvatska O, Schellenberg GD, Dawson G, de Bildt A, Minderaa RB, Mulder EJ, Morris AP, Bailey AJ, Monaco AP; IMGSAC. Highdensity SNP association study and copy number variation analysis of the AUTS1 and AUTS5 loci implicate the IMMP2L-DOCK4 gene region in autism susceptibility. Mol Psychiatry. 15(9):954-68, 2010.

McCarroll SA, Huett A, Kuballa P, Chilewski SD, Landry A, Goyette P, Zody MC, Hall JL, Brant SR, Cho JH, Duerr RH, Silverberg MS, Taylor KD, Rioux JD, Altshuler D, Daly MJ, Xavier RJ. Deletion polymorphism upstream of IRGM associated with altered IRGM expression and Crohn's disease. Nat Genet. 40(9):1107-12, 2008.

Mese G, Londin E, Mui R, Brink PR, White TW. Altered gating properties of functional Cx26 mutants associated with recessive non-syndromic hearing loss. Hum Genet. 115(3):191-9, 2004.

Milunsky JM, Maher TA, Ito M, Milunsky A. The value of MLPA in Waardenburg syndrome. Genet Test. 11(2):179-82, 2007.

Morton Human Fetal Cochlea cDNA Library EST Data. URL: <http://www.brighamandwomens.org/bwh_hearing/human-cochlear-ests.aspx>. Acesso em: 9 mar. 2008. 
Mustapha M, Salem N, Weil D, el-Zir E, Loiselet J, Petit C. Identification of a locus on chromosome 7q31, DFNB14, responsible for prelingual sensorineural non-syndromic deafness. Eur J Hum Genet. 6(6):548$51,1998$.

Nobrega M, Weckx LL, Juliano Y. Study of the hearing loss in children and adolescents, comparing the periods of 1990-1994 and 1994-2000. Int J Pediatr Otorbinolaryngol. 69(6):829-38, 2005.

Nunnari J, Fox TD, Walter P. A mitochondrial protease with two catalytic subunits of nonoverlapping specificities. Science. 262(5142):1997-2004, 1993.

OMIM. Online Mendelian Inheritance in Man. URL: <http://www.ncbi.nlm.nih.gov/omim>. Acesso em: 9 mar. 2008.

Oostlander AE, Meijer GA, Ylstra B. Microarray-based comparative genomic hybridization and its applications in human genetics. Clin Genet. 66(6):488-95, 2004.

Pagnamenta AT, Bacchelli E, de Jonge MV, Mirza G, Scerri TS, Minopoli F, Chiocchetti A, Ludwig KU, Hoffmann P, Paracchini S, Lowy E, Harold DH, Chapman JA, Klauck SM, Poustka F, Houben RH, Staal WG, Ophoff RA, O'Donovan MC, Williams J, Nöthen MM, Schulte-Körne G, Deloukas P, Ragoussis J, Bailey AJ, Maestrini E, Monaco AP; International Molecular Genetic Study Of Autism Consortium. Characterization of a family with rare deletions in CNTNAP5 and DOCK4 suggests novel risk loci for autism and dyslexia. Biol Psychiatry. 68(4):320-8, 2010.

Pallares-Ruiz N, Blanchet P, Mondain M, Claustres M, Roux AF. A large deletion including most of GJB6 in recessive non syndromic deafness: a digenic effect? Eur J Hum Genet. 10(1):72-6, 2002.

Pandya A, Xia X, Radnaabazar J, Batsuuri J, Dangaansuren B, Fischel-Ghodsian N, Nance WE. Mutation in the mitochondrial $12 \mathrm{~S}$ rRNA gene in two families from Mongolia with matrilineal aminoglycoside ototoxicity. J Med Genet. 34(2):169-72, 1997.

Pera A, Villamar M, Viñuela A, Gandía M, Medà C, Moreno F, Hernández-Chico C. A mutational analysis of the SLC26A4 gene in Spanish hearing-impaired families provides new insights into the genetic causes of Pendred syndrome and DFNB4 hearing loss. Eur J Hum Genet. 16(8):888-96, 2008.

Petek E, Schwarzbraun T, Noor A, Patel M, Nakabayashi K, Choufani S, Windpassinger C, Stamenkovic M, Robertson MM, Aschauer HN, Gurling HM, Kroisel PM, Wagner K, Scherer SW, Vincent JB. Molecular and genomic studies of IMMP2L and mutation screening in autism and Tourette syndrome. Mol Genet Genomics. 277(1):71-81, 2007.

Petek E, Windpassinger C, Vincent JB, Cheung J, Boright AP, Scherer SW, Kroisel PM, Wagner K. Disruption of a novel gene (IMMP2L) by a breakpoint in 7q31 associated with Tourette syndrome. Am J Hum Genet. 68(4):848-58, 2001.

Prezant TR, Agapian JV, Bohlman MC, Bu X, Oztas S, Qiu WQ, Arnos KS, Cortopassi GA, Jaber L, Rotter JI, Shohat M, Fischel-Ghodsian N. Mitochondrial ribosomal RNA mutation associated with both antibiotic-induced and non-syndromic deafness. Nat Genet. 4(3):289-94, 1993.

Rabionet R, Gasparini P, Estivill X. Molecular genetics of hearing impairment due to mutations in gap junction genes encoding beta connexins. Hum Mutat. 16(3):190-202, 2000.

Ramoz N, Rueda, LA, Bouadjar, B, Montoya, LS, Orth, G, Favre, M. Mutations in two adjacent novel genes are associated with epidermodysplasia verruciformis. Nat Genet. 32: 487-9, 2002.

Redon R, Ishikawa S, Fitch KR, Feuk L, Perry GH, Andrews TD, Fiegler H, Shapero MH, Carson AR, Chen W, Cho EK, Dallaire S, Freeman JL, González JR, Gratacòs M, Huang J, Kalaitzopoulos D, Komura D, MacDonald JR, Marshall CR, Mei R, Montgomery L, Nishimura K, Okamura K, Shen F, Somerville MJ, Tchinda J, Valsesia A, Woodwark C, Yang F, Zhang J, Zerjal T, Zhang J, Armengol L, 
Conrad DF, Estivill X, Tyler-Smith C, Carter NP, Aburatani H, Lee C, Jones KW, Scherer SW, Hurles ME. Global variation in copy number in the human genome. Nature. 444:444-54, 2006.

Risheg H, Keitges E, Bumside RD, Gadi I, Jaswaney V, Pasion R, Schwartz S, Tepperberg J, Papenhausen P. Assessing the phenotypic effects of IMMP2L and DOCK4 detected by whole genome SNP array. In: 60 An Annual American Society of Human Genetics Meeting. Disponível em: < http://www.ashg.org/cgi-bin/2010/showdetail.pl?absno=22426>. Acesso em: 28 out. 2010.

Rodriguez-Revenga L, Mila M, Rosenberg C, Lamb A, Lee C. Structural variation in the human genome: the impact of copy number variants on clinical diagnosis. Genet Med. 9(9):600-6, 2007.

Rozen S, Skaletsky H. Primer3 on the WWW for general users and for biologist programmers. Methods Mol Biol. 132:365-86, 2000.

Schouten JP, McElgunn CJ, Waaijer R, Zwijnenburg D, Diepvens F, Pals G. Relative quantification of 40 nucleic acid sequences by multiplex ligation-dependent probe amplification. Nucleic Acids Res. 30(12):e57, 2002.

Sebat J, Lakshmi B, Troge J, Alexander J, Young J, Lundin P, Månér S, Massa H, Walker M, Chi M, Navin N, Lucito R, Healy J, Hicks J, Ye K, Reiner A, Gilliam TC, Trask B, Patterson N, Zetterberg A, Wigler M. Large-scale copy number polymorphism in the human genome. Science. 305(5683):525-8, 2004.

Shen Y, Wu BL. Designing a simple multiplex ligation-dependent probe amplification (MLPA) assay for rapid detection of copy number variants in the genome. J Genet Genomics. 36(4):257-65, 2009.

Smith RJH, Hildebrand MS, Van Camp G. Deafness and hereditary hearing loss overview. In: Pagon RA (Ed.). Gene reviews. Seattle: University of Washington, Seattle, 1993-. Disponível em: $<$ http://www.ncbi.nlm.nih.gov/bookshelf/br.fcgi?book=gene\&part=deafness-overview $>$. Acesso em: 2 aug. 2010.

Stankiewicz P, Lupski JR. Structural variation in the human genome and its role in disease. Annu Rev Med. 61:437-55, 2010.

The auditory system. In: Purves D. (Ed.). Neuroscience. Sunderland: Sinauer Associates, 2001. Disponível em: $<$ http://www.ncbi.nlm.nih.gov/bookshelf/br.fcgi?book=neurosci\&part=A879>. Acesso em: 24 out. 2010.

Tlili A, Masmoudi S, Dhouib H, Bouaziz S, Rebeh IB, Chouchen J, Turki K, Benzina Z, Charfedine I, Drira M, Ayadi H. Localization of a novel autosomal recessive non-syndromic hearing impairment locus DFNB63 to chromosome 11q13.3-q13.4. Ann Hum Genet. 71:271-5, 2006.

Tyson C, McGillivray B, Chijiwa C, Rajcan-Separovic E. Elucidation of a cryptic interstitial 7q31.3 deletion in a patient with a language disorder and mild mental retardation by array-CGH. Am J Med Genet $A$. 129A(3):254-60, 2004.

UCSC Genome Browser Home. URL: < http://genome.ucsc.edu/>. Acesso em: 23 abr. 2008.

Ueda S, Fujimoto S, Hiramoto K, Negishi M, Katoh H. Dock4 regulates dendritic development in hippocampal neurons. J Neurosci Res. 86(14):3052-61, 2008.

UniGene. URL: <http://www.ncbi.nlm.nih.gov/UniGene>. Acesso em: 9 mar. 2008.

Usami S, Abe S, Weston MD, Shinkawa H, Van Camp G, Kimberling WJ. Non-syndromic hearing loss associated with enlarged vestibular aqueduct is caused by PDS mutations. Hum Genet. 104(2):188-92, 1999. 
Van Camp G, Smith RJH. Hereditary hearing loss homepage. URL: <http://hereditaryhearingloss.org/>. Acesso em: 14 out. 2010.

Verpy E, Leibovici M, Zwaenepoel I, Liu XZ, Gal A, Salem N, Mansour A, Blanchard S, Kobayashi I, Keats BJ, Slim R, Petit C. A defect in harmonin, a PDZ domain-containing protein expressed in the inner ear sensory hair cells, underlies Usher syndrome type 1C. Nat Genet. 26(1):51-5, 2000.

Verpy E, Masmoudi S, Zwaenepoel I, Leibovici M, Hutchin TP, del Castillo I, Nouaille S, Blanchard S, Lainé S, Popot JL, Moreno F, Mueller RF, Petit C. Mutations in a new gene encoding a protein of the hair bundle cause non-syndromic deafness at the DFNB16 locus. Nat Genet. 29(3):345-9, 2001.

Vissers LE, de Vries BB, Osoegawa K, Janssen IM, Feuth T, Choy CO, Straatman H, van der Vliet W, Huys EH, van Rijk A, Smeets D, van Ravenswaaij-Arts CM, Knoers NV, van der Burgt I, de Jong PJ, Brunner HG, van Kessel AG, Schoenmakers EF, Veltman JA. Array-based comparative genomic hibridization for the genomewide detection of submicroscopic chromosomal abnormalities. Am J Hum Genet. 71:1261-70, 2003.

Wilch E, Azaiez H, Fisher RA, Elfenbein J, Murgia A, Birkenhäger R, Bolz H, Da Silva-Costa SM, del Castillo I, Haaf T, Hoefsloot L, Kremer H, Kubisch C, Le Marechal C, Pandya A, Sartorato EL, Schneider E, Van Camp G, Wuyts W, Smith RJ, Friderici KH. A novel DFNB1 deletion allele supports the existence of a distant cis-regulatory region that controls GJB2 and GJB6 expression. Clin Genet. 78(3):267-74, 2010.

Wilcox SA, Osborn AH, Allen-Powell DR, Maw MA, Dahl HH, Gardner RJ. Connexin26 deafness in several interconnected families. J Med Genet. 36(5):383-5, 1999.

Willems PJ. Mechanism of Disease: Genetic Causes of Hearing Loss. N Engl J Med 342(15): 1101-9, 2000.

Yajnik V, Paulding C, Sordella R, McClatchey AI, Saito M, Wahrer DC, Reynolds P, Bell DW, Lake R, van den Heuvel S, Settleman J, Haber DA. DOCK4, a GTPase activator, is disrupted during tumorigenesis. Cell. 112(5):673-84, 2003.

Yan D, Li F, Hall ML, Sage C, Hu WH, Giallourakis C, Upadhyay G, Ouyang XM, Du LL, Bethea JR, Chen ZY, Yajnik V, Liu XZ. An isoform of GTPase regulator DOCK4 localizes to the stereocilia in the inner ear and binds to harmonin (USH1C). J Mol Biol. 357(3):755-64, 2006.

Zhang F, Gu W, Hurles ME, Lupski JR. Copy number variation in human health, disease, and evolution. Annu Rev Genomics Hum Genet. 10:451-81, 2009.

Zhang Y, Malekpour M, Al-Madani N, Kahrizi K, Zanganeh M, Lohr NJ, Mohseni M, Mojahedi F, Daneshi A, Najmabadi H, Smith RJ. Sensorineural deafness and male infertility: a contiguous gene deletion syndrome. J Med Genet. 44(4):233-40, 2007. 


\section{ANEXOS}

Cópia do parecer consubstanciado de projeto de pesquisa pelo CEP-IBUSP

Cópias dos termos de consentimento livre e esclarecido (menor e maior de idade) 


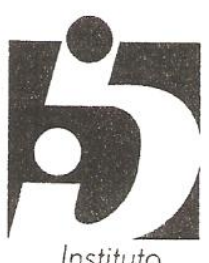

de Biociências

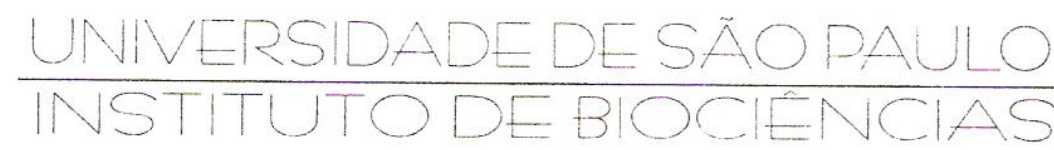

PARECER CONSUBSTANCIADO DE PROJETO DE PESQUISA

PROTOCOLO CEP-IBUSP - 083/2008

TÍTULO DO PROJETO DE PESQUISA: "Busca de novos genes de surdez sindrômica e não sindrômica: uma abordagem cromossômica e molecular" - FR 204592 .

Pesquisadora Responsável: Daniela Tiaki Uehara

Orientadora: Profa. Dra. Regina Célia Mingroni Netto

Objetivos do projeto de pesquisa: Identificar novos genes relacionados à manifestação de surdez sindrômica e não-sindrômica pela triagem de deleções/duplicações nos genes candidatos selecionados a partir de pacientes com alterações cromossômicas previamente descritas, e em novos pacientes, assim como, investigar mutações de ponto nesses genes em outros pacientes da casuística.

Local da realização do projeto, duração e financiamento: $O$ projeto será desenvolvido no Departamento de Genética e Biologia Evolutiva do Instituto de Biociências da USP. A duração prevista é de 6 semestres (3 anos) e contará com financiamento da FAPESP.

Comentários: O projeto de pesquisa contém descrição dos propósitos e das hipóteses a serem testadas, assim como os antecedentes científicos e os dados que justificam a pesquisa. O projeto de pesquisa está detalhado e ordenado em Introdução, Justificativa, Objetivos, Casuística e Métodos, Proposta de Cronograma, Referências Bibliográficas. O laboratório na qual a pesquisadora atua presta serviço de Aconselhamento Genético para as famílias de afetados e os testes moleculares são realizados em DNA extraído de sangue periférico cuja coleta representa risco mínimo para os pacientes. Há anuência da instituição, e o projeto conta com verba FAPESP. O projeto se constituirá na Dissertação de Mestrado da pesquisadora que está matriculada no Programa Biologia/Genética do Departamento de Genética e Biologia Evolutiva - IBUSP. O laboratório conta com a infra-estrutura necessária para o desenvolvimento da pesquisa e para recepção, entrevista e coleta de sangue periférico dos pacientes e familiares. Aos pacientes e familiares serão fornecidos os resultados da pesquisa (positivos ou negativos) e o sigilo e o princípio da confidencialidade foram garantidos. As informações relativas aos sujeitos da pesquisa, pacientes e familiares estão bem delineadas. O Termo de Consentimento Livre e Esclarecido foi apresentado e está bem redigido; há o Termo de Consentimento para maiores e menores de 18 anos. O material colhido (DNA) será armazenado pelo prazo necessário para que o(s) gene(s) responsável(is) pela surdez hereditária seja(m) identificado(s). Os pacientes triados anteriormente serão analisados visando identificar a etiologia da doença. Os pacientes e/ou genitores (responsáveis) assinaram o Termo de Consentimento Livre e Esclarecido na ocasião da primeira consulta. 


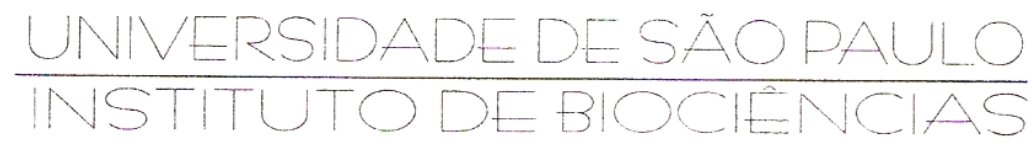

Instituto

de BiociêncidGonsiderações: $\mathrm{O}$ projeto apresentado preenche todos os pré-requisitos éticos conforme resolução CNS 196/96. Diante do Exposto, o Comitê de Ética em Pesquisa - Seres Humanos, de acordo com as atribuições definidas na Resolução CNS - 196/96, aprova o projeto de pesquisa proposto. O pesquisador responsável deverá apresentar, ao CEP, os relatórios anual e final.

Situação: Projeto APROVADO.

São Paulo, 16 de setembro de 2008.

Onao $\mathrm{Ne}$ - Bur

Profa. Dra. Maria Rita dos Santos e Passos Bueno

Coordenadora Substituta do Comitê de Ética em Pesquisa - Seres Humanos - IBUSP 


\title{
Universidade de São Paulo
}

Instituto de Biociências

\section{TERMO DE CONSENTIMENTO LIVRE E ESCLARECIDO}

\author{
(menores de 18 anos)
}

\section{ESTUDO: Busca de novos genes de surdez sindrômica e não-sindrômica: uma abordagem cromossômica e molecular}

Seu (Sua) filho(a) está sendo convidado a participar do projeto de pesquisa acima citado. $O$ documento abaixo contém todas as informações necessárias sobre a pesquisa que estamos fazendo. Sua colaboração neste estudo será de muita importância para nós.

$\mathrm{Eu}$,

RG , abaixo assinado(a), concordo de livre e espontânea vontade que meu (minha) filho(a) nascido(a) em I

/__ _ participe do estudo "Busca de novos genes de surdez sindrômica e não-sindrômica: uma abordagem cromossômica e molecular", e esclareço que obtive todas informações necessárias.

Estou ciente que:

I) $\quad$ O estudo se faz necessário para que possam descobrir as possíveis causas da doença denominada "Surdez hereditária";

II) Será feita coleta de $10 \mathrm{ml}$ de sangue do(a) meu(minha) filho(a);

III) Essa coleta será feita apenas para este estudo e em nada influenciará no tratamento de meu(minha) filho(a); não vai curá-lo(a); não causará nenhum problema, exceto a dor da picadinha da agulha no local da coleta;

IV) Tenho a liberdade de desistir ou interromper a colaboração neste estudo no momento em que desejar, sem necessidade de qualquer explicação;

V) A desistência não causará nenhum prejuízo a mim, nem ao(à) meu(minha) filho(a), e sem que venha interferir no atendimento ou tratamento médico; 
VI) Os resultados obtidos durante este ensaio serão mantidos em sigilo, mas concordo que sejam divulgados em publicações científicas, desde que nem o meu nome nem o de meu filho sejam mencionados;

VII) Caso eu desejar, poderei tomar conhecimento dos resultados ao final desta pesquisa

( ) Desejo conhecer os resultados desta pesquisa.

( ) Não desejo conhecer os resultados desta pesquisa.

VIII) Caso tenham sido tiradas fotografias,

( ) concordo que sejam incluídas em publicações científicas, se necessário

( ) concordo que sejam apresentadas em aulas para profissionais da saúde

( ) não concordo que sejam incluídas em nenhum tipo de publicação ou apresentação.

IX) O material colhido será armazenado pelo tempo considerado necessário para a identificação e caracterização do gene e de sua mutação e/ou mecanismo genético responsável pela doença observada na sua família.

São Paulo, de de

Participante:

Pesquisador Responsável pelo Projeto:

Daniela Tiaki Uehara

Bióloga

Pesquisador e instituição responsáveis pelas amostras de DNA:

Dra. Regina Célia Mingroni Netto

CRBio/SP 10.238-01

Depto de Genética e Biologia Evolutiva

Instituto de Biociências - USP

Telefone para contato: $3091-7478$ 


\title{
Universidade de São Paulo
}

Instituto de Biociências

\section{TERMO DE CONSENTIMENTO LIVRE E ESCLARECIDO}

\author{
(maiores de 18 anos)
}

\section{ESTUDO: Busca de novos genes de surdez sindrômica e não-sindrômica: uma abordagem cromossômica e molecular}

Você está sendo convidado(a) a participar do projeto de pesquisa acima citado. O documento abaixo contém todas as informações necessárias sobre a pesquisa que estamos fazendo. Sua colaboração neste estudo será de muita importância para nós.

$\mathrm{Eu}$, profissão

residente e domiciliado na portador da Cédula de identidade RG , inscrito no $\mathrm{CPF} / \mathrm{MF}$ e nascido(a) em I 1 , abaixo assinado(a), concordo de livre e espontânea vontade em participar do estudo "Busca de novos genes de surdez sindrômica e não-sindrômica: uma abordagem cromossômica e molecular”, e esclareço que obtive todas as informações.

Estou ciente que:

X) O estudo se faz necessário para que se possam descobrir as possíveis causas da doença denominada "Surdez hereditária";

XI) Será feita uma coleta de $10 \mathrm{ml}$ de sangue;

XII) Essa coleta será feita apenas para este estudo e em nada influenciará o meu tratamento; não vai me curar; não vai me causar nenhum problema, exceto o pequeno incômodo de dor no momento da coleta (introdução da agulha para retirada do sangue);

XIII) Tenho a liberdade de desistir ou de interromper a colaboração neste estudo no momento em que desejar, sem necessidade de qualquer explicação;

XIV) A desistência não causará nenhum prejuízo à minha saúde ou bem estar físico. Não virá interferir no atendimento ou tratamento médico; 
XV) Os resultados obtidos durante este ensaio serão mantidos em sigilo, mas concordo que sejam divulgados em publicações científicas, desde que meus dados pessoais não sejam mencionados;

XVI) Caso eu desejar, poderei tomar conhecimento dos resultados, ao final desta pesquisa:

( ) Desejo conhecer os resultados desta pesquisa.

( ) Não desejo conhecer os resultados desta pesquisa.

XVII) Caso tenham sido tiradas fotografias,

( ) concordo que sejam incluídas em publicações científicas, se necessário

( ) concordo que sejam apresentadas em aulas para profissionais da saúde

( ) não concordo que sejam incluídas em nenhum tipo de publicação ou apresentação.

IX) O material colhido será armazenado por um tempo considerado necessário para a identificação e caracterização do gene e de sua mutação e/ou mecanismo genético responsável pela doença observada na sua família.

São Paulo, de de

Participante:

Pesquisador Responsável pelo Projeto:

Daniela Tiaki Uehara

Bióloga

Pesquisador e instituição responsáveis pelas amostras de DNA:

Dra. Regina Célia Mingroni Netto

CRBio/SP 10.238-01

Depto de Genética e Biologia Evolutiva

Instituto de Biociências - USP

Telefone para contato: $3091-7478$ 